DOE/EIA-0585(93)

Distribution Category UC-950

\title{
Alternatives to Traditional Transportation Fuels 1993
}

\author{
January 1995
}

Energy Information Administration

Office of Coal, Nuclear, Electric and Alternate Fuels

U.S. Department of Energy

Washington, DC 20585

This report was prepared by the Energy Information Administration, the independent statistical and analytical agency within the Department of Energy. The information contained herein should not be construed as advocating or reflecting any policy of the Department of Energy or of any other organization. 


\section{Contacts}

This report was prepared by the Energy Information Administration (EIA), Office of Coal, Nuclear, Electric and Alternate Fuels (CNEAF). General information about data in this document may be obtained from the National Energy Information Center (202/586-8800). Further information about the report may be obtained from Howard Walton
(202/254-5500), Director of the Survey Management Division; Fred Mayes (202/254-5300), Chief of the Renewable and Financial Data Systems and Outreach Branch; James Disbrow (202/254-5558), Team leader; Mary Joyce (202/254-9829); or Jorge Luna-Camara (202/254-5664). 


\section{DISCLAIMER}

This report was prepared as an account of work sponsored by an agency of the United States Government. Neither the United States Government nor any agency thereof, nor any of their employees, make any warranty, express or implied, or assumes any legal liability or responsibility for the accuracy, completeness, or usefulness of any information, apparatus, product, or process disclosed, or represents that its use would not infringe privately owned rights. Reference herein to any specific commercial product, process, or service by trade name, trademark, manufacturer, or otherwise does not necessarily constitute or imply its endorsement, recommendation, or favoring by the United States Government or any agency thereof. The views and opinions of authors expressed herein do not necessarily state or reflect those of the United States Government or any agency thereof. 


\section{DISCLAIMER}

Portions of this document may be illegible in electronic image products. Images are produced from the best available original document. 


\section{Contents}

Executive Summary $\ldots \ldots \ldots \ldots \ldots \ldots \ldots \ldots \ldots \ldots \ldots \ldots \ldots \ldots \ldots \ldots \ldots \ldots \ldots \ldots \ldots \ldots$

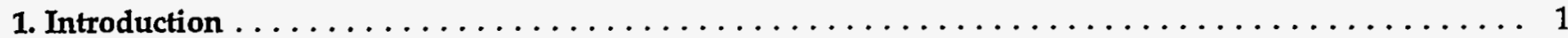

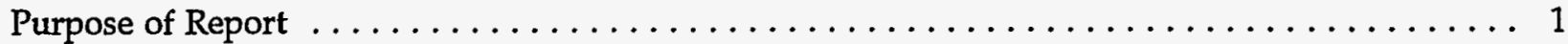

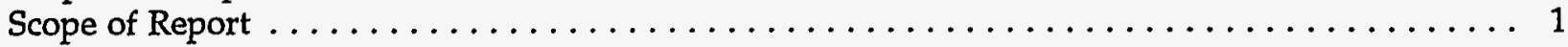

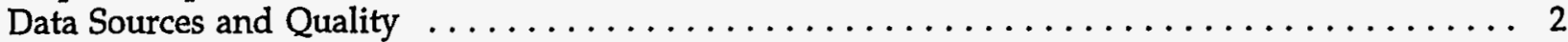

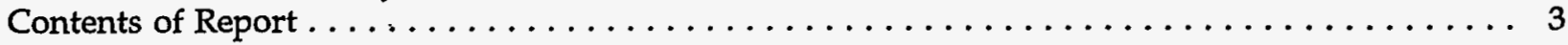

2. Alternative Fueled Vehicle Inventory $\ldots \ldots \ldots \ldots \ldots \ldots \ldots \ldots \ldots \ldots \ldots \ldots \ldots \ldots \ldots \ldots \ldots \ldots \ldots$

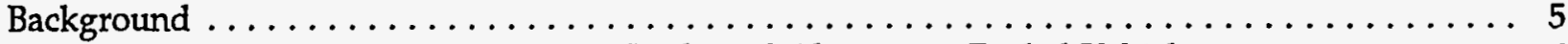

Types of Alternative Transportation Fuels and Alternative Fueled Vehicles . . . . . . . 6

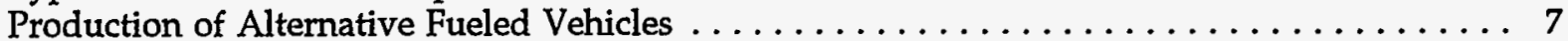

Estimated Vehicle Stocks in 1992,1993 , and $1995 \ldots \ldots \ldots \ldots \ldots \ldots \ldots \ldots \ldots \ldots \ldots \ldots$

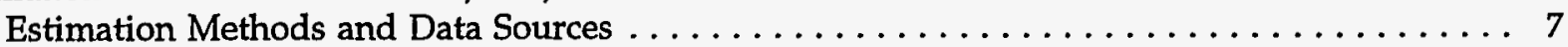

Alternative Fueled Vehicles by Fuel Type, Ownership, and Weight Class, $1992 \ldots \ldots \ldots \ldots 7$

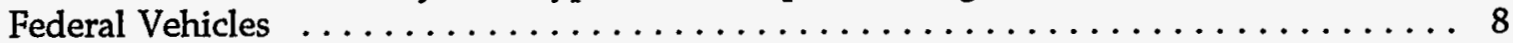

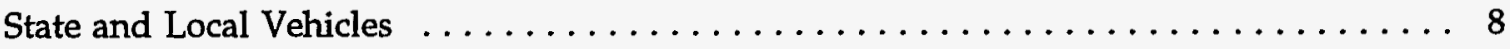

Privately Owned Vehicles ............................... 9

Alternative Fueled Vehicles by Fuel Type, Ownership, and Weight Class, 1993 and

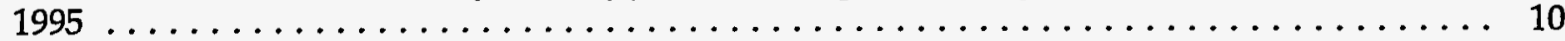

Regional Distribution of AFV's for 1993 and $1995 \ldots \ldots \ldots \ldots \ldots \ldots \ldots \ldots \ldots \ldots \ldots \ldots$

Trends in Alternative Fueled Vehicle Inventories, 1992 to $1995 \ldots \ldots \ldots \ldots \ldots \ldots \ldots \ldots 11$

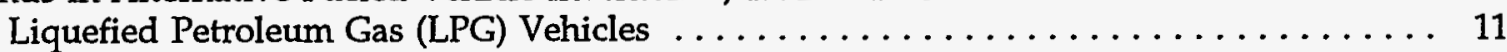

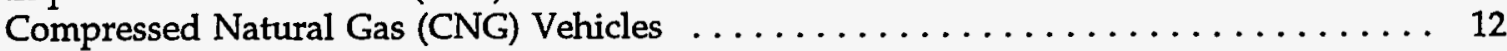

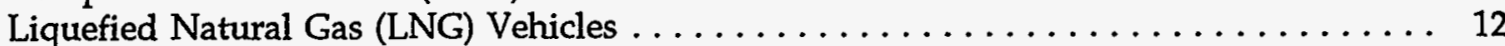

Methanol (M85) Vehicles . . . . . . . . . . . . . . . . . . . . . 13

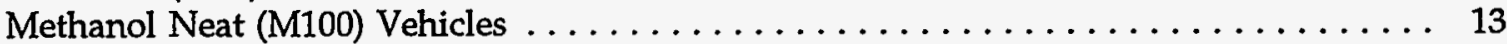

Ethanol (E85) Vehicles . . . . . . . . . . . . . . . . . . . . . . . 13

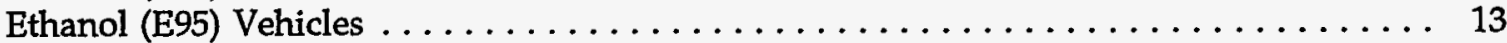

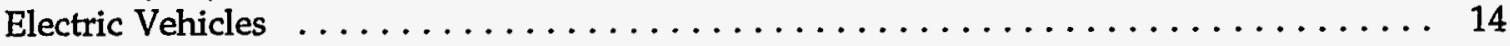

3. Alternative and Replacement Fuel Consumption $\ldots \ldots \ldots \ldots \ldots \ldots \ldots \ldots \ldots \ldots \ldots \ldots \ldots \ldots$

Background . . . . . . . . . . . . . . . . . . . . . . . . . . . 17

Estimated Vehicle Fuel Consumption in 1992, 1993, and $1995 \ldots \ldots \ldots \ldots \ldots \ldots \ldots \ldots \ldots$

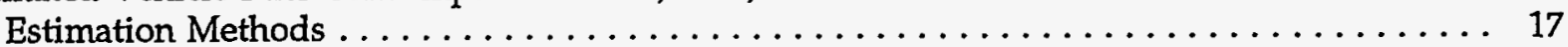

Alternative Fuel Consumption by Fuel Type, Vehicle Ownership, and Weight Class,

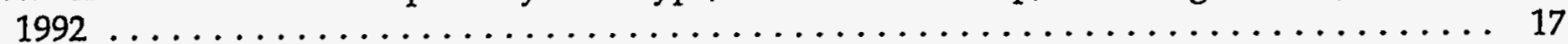

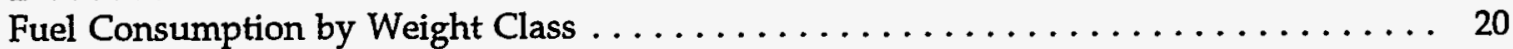

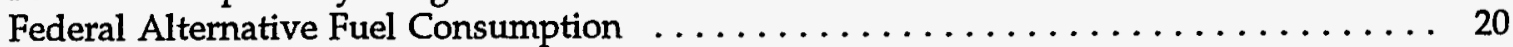

State and Local Government Alternative Fuel Consumption $\ldots \ldots \ldots \ldots \ldots \ldots \ldots \ldots$

Privately Owned Alternative Fueled Vehicle Consumption $\ldots \ldots \ldots \ldots \ldots \ldots \ldots \ldots 21$

Oxygenate Consumption in $1992 \ldots \ldots \ldots \ldots \ldots \ldots \ldots \ldots \ldots \ldots \ldots \ldots \ldots \ldots \ldots \ldots \ldots$

Alternative Fuel Consumption Estimates by Fuel Type, and by Vehicle Ownership and

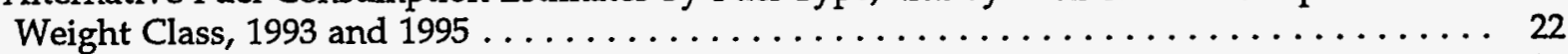

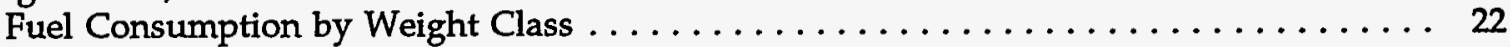

Federal Fuel Consumption . . . . . . . . . . . . . . . 22

State and Local Government Alternative Fuel Consumption $\ldots \ldots \ldots \ldots \ldots \ldots \ldots . \ldots \ldots$

Privately Owned Alternative Fueled Vehicle Consumption $\ldots \ldots \ldots \ldots \ldots \ldots \ldots \ldots . \ldots \ldots$

Oxygenate Consumption in 1993 and $1995 \ldots \ldots \ldots \ldots \ldots \ldots \ldots \ldots \ldots \ldots \ldots \ldots \ldots . \ldots \ldots$

Regional Distribution of Alternative and Oxygenate Fuel Consumption for 1993 and

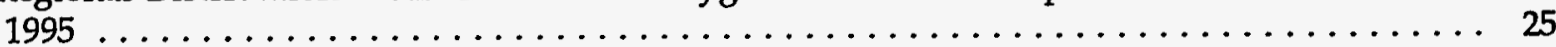




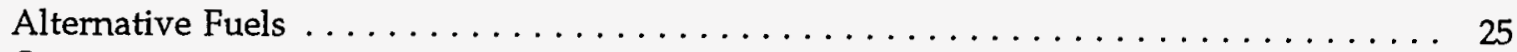

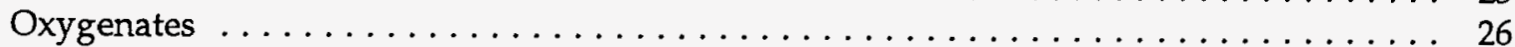

4. Greenhouse Gas Emissions . . . . . . . . . . . . . . . . . . . . . . . . . . . . . . . . . . . 29

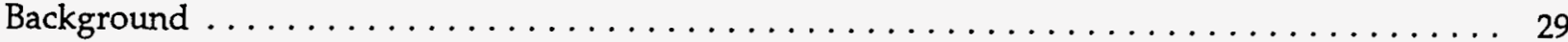

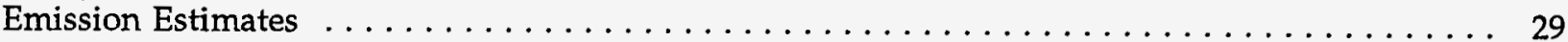

Direction of Future Greenhouse Gas Emission Estimates $\ldots \ldots \ldots \ldots \ldots \ldots \ldots \ldots \ldots \ldots$

Appendices

A. U.S. Census Region Map . . . . . . . . . . . . . . . . . . . . . . 37

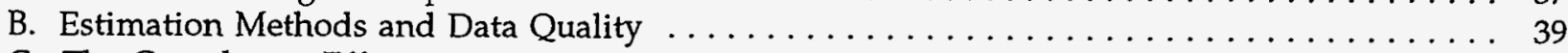

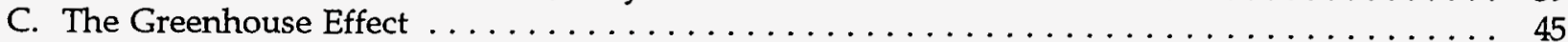

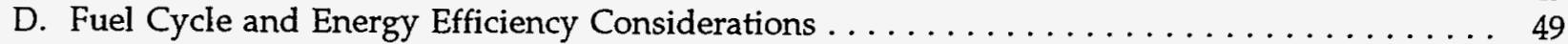

E. Biomass Land-use Impacts on Greenhouse Gases . . . . . . . . . . . . . . . . . . . . . 55

F. List of Converters, Original Equipment Manufacturers, and Training Centers . . . . . . 57

Glossary $\ldots \ldots \ldots \ldots \ldots \ldots \ldots \ldots \ldots \ldots \ldots \ldots \ldots \ldots \ldots \ldots \ldots \ldots \ldots \ldots \ldots$ 
1. Estimated Alternative Fueled Vehicles in Use by Fuel, 1992, 1993, and $1995 \ldots \ldots \ldots \ldots \ldots$

2. Estimation Methods and Sources for Privately Owned and State and Local Government Vehicle Counts 9

3. Estimated Alternative Fueled Vehicles in Use by Fuel, Ownership, and Weight Class, 1992 . . . . . 10

4. Estimated Alternative Fueled Vehicles in Use by Fuel, Ownership, and Weight Class, 1993 . . . . . 11

5. Projected Alternative Fueled Vehicles in Use by Fuel, Ownership, and Weight Class, 1995 . . . . . . 12

6. Estimated Privately Owned and State and Local Government Alternative Fueled Vehicles in Use by Census Region 1993 . . . . . . . . . . . . . . . . . . . . . . . . . . . . . 13

7. Projected Privately Owned and State and Local Government Alternative Fueled Vehicles in Use by Census

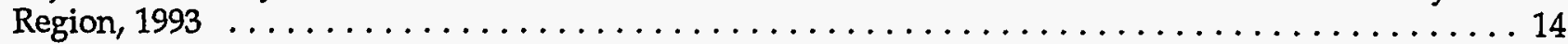

8. Consumption of Vehicle Fuels, 1992 1993, and $1995 \ldots \ldots \ldots \ldots \ldots \ldots \ldots \ldots \ldots \ldots \ldots \ldots \ldots$

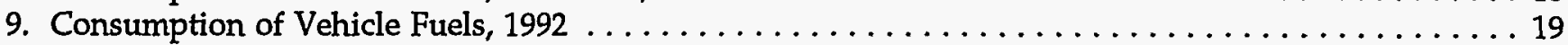

10. Consumption of Alternative Fuels by Vehicle Weight Classification, $1992 \ldots \ldots \ldots \ldots \ldots \ldots$

11. Consumption of Alternative Fuels by Vehicle Ownership Class, $1992 \ldots \ldots \ldots \ldots \ldots \ldots \ldots \ldots$

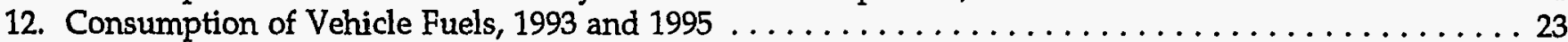

13. Consumption of Alternative Fuels by Vehicle Weight Classification, 1993 and 1995 . . . . . . . . . 24

14. Consumption of Alternative Fuels by Vehicle Ownership Class, 1993 and 1995 . . . . . . . . . . . 25

15. Non-Federal Consumption of Liquified Petroleum Gases and Natural Gas by Region, 1993 and 1995 . 27

16. Consumption of Alcohol Fuels by Region, 1993 and $1995 \ldots \ldots \ldots \ldots \ldots \ldots \ldots \ldots \ldots \ldots \ldots \ldots$

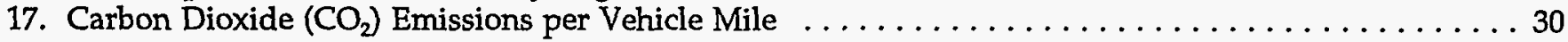

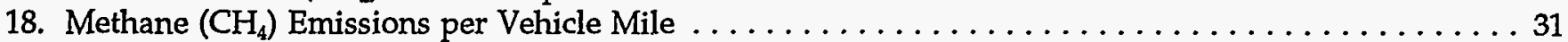

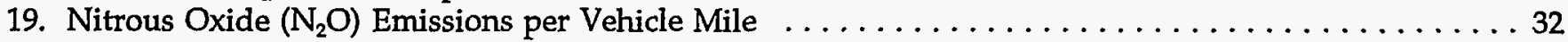

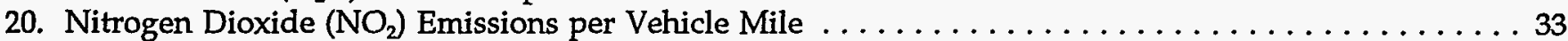

21. Carbon Monoxide (CO) Emissions per Vehicle Mile . . . . . . . . . . . . . . . . . . 34

22. Total Fuel-Cycle Emissions from Gasoline and from Alternative and Replacement Fuels . . . . . . . 35

B1. Alternative Fueled Vehicles Distribution by Vehicle, Fuel, Ownership, and Classification, 1995 . . . . 41

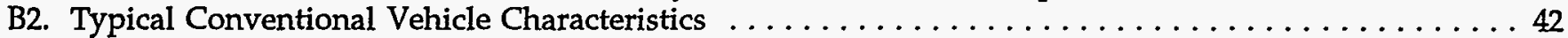

B3. Original and Adjusted Lower Heating Values of Conventional and Replacement Fuels . . . . . . 43

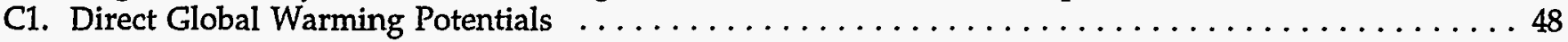

D1. Energy Efficiency for Stages in Providing Transportation Fuels to Consumers . . . . . . . . 52

D2. Energy Consumption for Stages in Providing Transportation Fuels to Consumers ......... 53

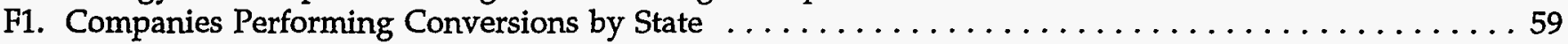

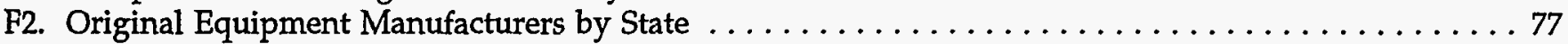

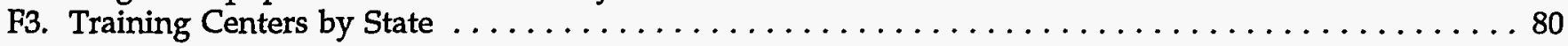

\section{Figures}

1. Alternative Fuel Vehicle Configurations and Fuel Types $\ldots \ldots \ldots \ldots \ldots \ldots \ldots \ldots \ldots \ldots$

D1. Entire Fuel Cycle for Transportation Fuels $\ldots \ldots \ldots \ldots \ldots \ldots \ldots \ldots \ldots \ldots \ldots \ldots \ldots \ldots \ldots$ 


\section{Executive Summary}

Growing concerns about the environmental effects of fossil fuel use and the Nation's high level of dependence on foreign oil are providing impetus for the development of replacements for traditional transportation fuels. The Alternative Motor Fuels Act of 1988, the Clean Air Act Amendments of 1990 (CAAA) and the Energy Policy Act of 1992 (EPACT) are significant legislative forces behind the growth of replacement fuel consumption. Alternatives to Traditional Transportation Fuels 1993 provides the number of on-road alternative fueled vehicles (AFV's) in use in the United States, alternative and replacement fuel consumption, and information on greenhouse gas emissions resulting from the entire transportation fuel cycle for 1992, 1993, and $1995 .^{1}$

\section{Alternative Fueled Vehicle Inventory}

In 1992, at least 251,000 AFV's were in use in the United States. By 1993, there were at least 315,000 AFV's in use; in 1995, the number of AFV's is expected to exceed 418,000 , a 66 percent increase from 1992.

- As in previous years, the majority (71 percent) of AFV's in 1995 will be fueled by liquefied petroleum gases (LPG). Vehicles operating on compressed natural gas (CNG) will comprise the second-largest share of AFV's in use at 22 percent. Vehicles that can operate on a mixture of 85 percent methanol and 15 percent gasoline (M85) will represent 5 percent of AFV's in use. The remaining AFV's will be fueled by electricity, liquefied natural gas (LNG), neat methanol (M100), and ethanol/gasoline mixtures containing 85 percent ethanol (E85) or 95 percent ethanol (E95).

- Over 81 percent of the AFV's in use in 1995 will be owned by the private sector. The share of vehicles owned by State and local governments will be 14 percent, while the share for the Federal Government will be 5 percent. However, the inventory of government AFV's is expected to grow at a relatively faster rate than the inventory of privatelyowned AFV's by virtue of new government AFV acquisition programs. Private sector and State/local government fleets are expected to rely most heavily on L.PG-, CNG-, and M85fueled vehicles. Together, these vehicle types are expected to represent 98 percent of all AFV's in use in 1995. The Federal AFV fleet in 1995 will rely on M85 and CNG for 80 percent of its AFV's.

- In 1995, 79 percent of all AFV's will be light duty (less than or equal to 8,500 pounds gross vehicle weight, such as automobiles and pickup trucks), while 21 percent will be heavy duty (over 8,500 pounds gross vehicle weight). Heavy-duty vehicles will represent only 0.3 percent of the total Federal AFV's in 1995. In contrast, heavy-duty vehicles will represent 22 percent of all privately-owned AFV's.

- The majority of AFV's in 1995 will be located in the South and West Census Regions, due largely to the sizable number of AFV's in California and Texas. While LPG vehicles are more evenly distributed across the Census Regions, 68 percent of the CNG-fueled vehicles will be in the South and the West. Only a few of the methanol vehicles will be located outside of the West. Of the ethanol-fueled vehicles, 95 percent will be in the Midwest. The majority of electric vehicles will be in the West.

\section{Alternative and Replacement Fuel Consumption}

In 1992, alternative and replacement fuels accounted for 1.6 percent of on-road transportation fuel consumption (on a gasoline-gallon equivalent basis). By 1995, the market share will double, reaching 3.3 percent. Oxygenates, which are defined as replacement fuels in EPACT, represented 89.1 percent of the alternative and replacement fuel market in 1992 and are expected to account for 91.9 percent in 1995. Federal legislation, Federal and State incentive programs, and cooperative efforts by fuel suppliers, are principally responsible for the large increase in market penetration for both alternative fuels and oxygenates.

- Liquefied petroleum gases dominated the alternative fuel market in 1992 with a 90.6 percent share. Although the on-road consumption of LPG is expected to increase 41 percent from 1992 to 1995 (from 208 million to 294 
million gasoline-equivalent gallons), LPG share of the alternative fuel market in 1995 will decrease to 79 percent due to the higher relative growth rates of the other alternative fuels, especially CNG. The Northeast Census Region is the smallest LPG consumer, while consumption is relatively evenly distributed among the other Regions.

- Approximately 17 million gasoline-equivalent gallons of CNG were consumed in 1992. Consumption is expected to increase almost four-fold by 1995 . Compressed natural gas share of the alternative fuel market should reach 18 percent in 1995. Most CNG consumption occurs in the West and South Census . Regions, with these Regions representing a combined 68 percent of the Nation's total CNG consumption in 1993 and 1995.

- The on-road fuel consumption of other alternative fuels (M100, M85, E95, E85, LNG, and electricity) is expected to significantly increase from 1992 to 1995, although these fuels will continue to represent a small fraction of the total alternative fuel market. Consumption of M85 and E85 increases the most from 1992 to 1995, with M85 consumption more than tripling (from 1.1 million to 3.4 million gasolineequivalent gallons), and E85 more than quadrupling (from 21,000 to 89,000 gasoline-equivalent gallons). Consumption of M85 and M100 is concentrated in the West Census Region, while consumption of E85 and E95 fuel is concentrated in the Midwest Census Region.

- Projections of alternative fuel consumption are influenced by the assumed mix of vehicle types (as determined by weight class and fuel system configurations) and the number of AFV's expected to be in use.

- The demand for oxygenates (methyl tertiary butyl ether (MTBE), ethanol in gasohol, and other alcohols and ethers) is expected to more than double from 1992 to 1995 , increasing from 1.9 billion to 4.2 billion gasoline-equivalent gallons. Factors contributing to the expected consumption increase include CAAA oxygenated and reformulated gasoline requirements initiated prior to, and during, the forecast period. Consumption of $\mathrm{MTBE}$ is expected to increase about 170 percent from 1992 to 1995 ( 1.2 billion to 3.1 billion gasoline-equivalent gallons), while ethanol used as a fuel additive is expected to increase by 24 percent, from 701 million to 871 million gasoline-equivalent gallons. Other oxygenates, primarily ethyl tertiary butyl ether (ETBE) and tertiary amyl methyl ether (TAME), are expected to penetrate the oxygenate market during the forecast period, reaching an oxygenates market share of 4.4 percent by 1995.

\section{Greenhouse Gas Emissions}

Alternatives to Traditional Transportation Fuels: An Overview presented information on greenhouse gas emissions resulting from replacement fuels' use relative to unleaded gasoline. ${ }^{2}$ The Energy Information Administration (EIA) received input from experts as part of the information development process, a process which will continue as research unfolds. The method by which this information continues to be developed is explained in this report, along with a description of the many complexities surrounding the subject.

Building on what others have begun, the EIA is working toward producing its own set of energy efficiency and emissions tables on both a grams-permillion-Btu basis for production of vehicle fuel, as well as a grams-per-mile basis taking into account the entire fuel cycle. After the EIA evaluated several relevant studies, a Department of Energy (DOE) analysis was chosen as the starting point for developing assumptions and methods to be used to create the EIA emissions tables. ${ }^{3}$ Plans include developing emission factors by vehicle type to be applied to the vehicle information being collected by the EIA. Subsequent reports will display total greenhouse gas emissions from actual use of the different fuels.

Greenhouse gas emissions from transportation fuels originate from every point in a fuel cycle in which energy is consumed: from resource extraction, from conversion to an engine fuel, from resource or fuel transportation, and from vehicle engine combustion. Generally, greenhouse gases are emitted as fuels are burned or evaporated. Thus, the basis of emissions estimates are the fuel types used in each fuel cycle stage, and the associated fuel quantities employed.

Some conclusions can be drawn from the existing knowledge base:

- Prior to vehicle use, the processing/conversion stage, where resources such as crude oil are processed into fuels, is usually the least energy 
efficient stage. As a result, a large percentage of the total fuel cycle emissions are produced in this stage.

- Compressed natural gas and LPG have the highest full fuel-cycle efficiencies, followed by gasoline, methanol and ethanol. The full fuel cycle efficiency is the final amount of energy delivered at the refueling point divided by all the energy input in all of the stages.

- Carbon dioxide $\left(\mathrm{CO}_{2}\right)$ emissions are lowest for CNG and LPG since these fuels require neither conversion nor much processing to be used as a transportation fuel. Both of these fuels have a very low carbon to hydrogen ratio relative to the other fuels.
- A major factor contributing to alcohol $\mathrm{CO}_{2}$ emissions is low energy efficiencies associated with converting feedstocks into fuel. Consequently, for the stages prior to vehicle combustion, the alcohol transportation fuels produce the largest volume of $\mathrm{CO}_{2}$ emissions per million Btu, relative to the other fuels. However, when the vehicle combustion stage is considered, the situation changes; the alcohols produce fewer $\mathrm{CO}_{2}$ emissions than do traditional fuels, but still more than CNG and LPG. In the case of ethanol, this result stems from the assumption that $\mathrm{CO}_{2}$ emissions are recycled back into biofuel crops, and that a credit for this recycling process is taken at the combustion stage of the ethanol fuel cycle.

\section{Notes}

'A transportation fuel cycle begins with energy resource recovery and ends with fuel consumption.

2Energy Information Administration, Alternatives to Transportation Fuels: An Overview, DOE/EIA-05850 (Washington, DC, June 1994).

${ }^{3}$ Argonne National Laboratory, Center for Transportation Research, Emissions of Greenhouse Gases from the Use of Transportation Fuels and Electricity, ANL/ESD/TM-22, Prepared by Dr. Mark A. DeLuchi, Vol 1 (Argonne, IL, November 1991) and Vol 2 (Argonne, IL, November 1993). 


\section{Introduction}

In recent years, gasoline and diesel fuel have accounted for about 80 percent of total transportation fuel and nearly all of the fuel used in on-road vehicles. ${ }^{1}$ Growing concerns about the environmental effects of fossil fuel use and the Nation's high level of dependence on foreign oil are providing impetus for the development of replacements or alternatives for these traditional transportation fuels. (The Energy Policy Act of 1992 definitions of "replacement" and "alternative" fuels are presented in the following box.) The Alternative Motor Fuels Act of 1988, the Clean Air Act Amendments of 1990 (CAAA90) and the Energy Policy Act of 1992 (EPACT) are significant legislative forces behind the growth of replacement fuel use. Alternatives to Traditional Transportation Fuels 1993 provides the number of on-road alternative fueled vehicles in use in the United States, alternative and replacement fuel consumption, and information on greenhouse gas emissions resulting from the production, delivery, and use of replacement fuels for 1992, 1993, and 1995.

\section{Purpose of Report}

The EPACT, in order to encourage alternative and replacement fuel development and create a means of measuring market activity, called for several reports to be completed by Federal agencies. Section 503 of EPACT, titled "Replacement Fuel Demand Estimates and Supply Information," directs the Energy Information Administration (EIA) to estimate annually for both the preceding and the following calendar years: (1) the number of each type of alternative fueled vehicle (AFV) likely to be in use in the United States, (2) the probable geographic distribution of the vehicles, (3) the amount and distribution of each type of replacement fuel, and (4) the greenhouse gas emissions likely to result from replacement fuel use over the entire fuel cycle. Alternatives to Traditional Transportation Fuels 1993 is the first in a series of annual reports designed to provide such information.

In addition to specific EPACT data requirements, this report provides information that can serve as a basis for analyzing AFV and alternative and replacement fuel development. As the fuel markets develop, Alternatives to Traditional Transportation Fuels is intended to provide analysts with data and information to evaluate environmental and energy security issues, measure progress toward market development goals, and track the penetration of replacement fuels in the transportation fuel sector. The Alternatives to Traditional Transportation Fuels reports should also be useful for economic and many other types of analyses of replacement fuels.

In June 1994, the EIA provided background information on alternative and replacement fuels and furnished preliminary estimates of the use of AFV's and alternative transportation fuels (ATF) in the publication Alternatives to Traditional Transportation Fuels: An Overview (ATTF Overview). The ATTF Overoiew report, which serves as a reference document for this report, also contains technical information about topics such as ATF properties and production processes, AFV characteristics, legislation, and greenhouse gases. Alternatives to Traditional Transportation Fuels 1993 contains more data than the ATTF Overview report and presents vehicle stocks and fuel consumption projections for 1995. It also provides extended analyses of the greenhouse gas emissions and regional distribution issues.

\section{Scope of Report}

Alternatives to Traditional Transportation Fuels 1993 includes data about on-road AFV's in use, alternative and replacement fuel consumption, and greenhouse gas emissions from all transportation fuel cycles. ${ }^{2}$ This report provides vehicle and fuel data for 1992 and 1993, and projections for 1995. Data for 1993 and projections for 1995 were obtained from research completed in mid-1994, while baseline data for 1992 were obtained in 1993. Estimates for 1994, which were reported in the ATTF Overview, are not included because they were based on market outlook assumptions made in 1993. These market assumptions, in some cases, resulted in greater estimated 1994 market activity than what the EIA believes to have actually taken place.

In this report, estimates are provided only for those alternative and replacement fuels cited in the EPACT that are commercially available or produced in significant quantities for vehicle demonstration purposes. The following fuel types are included: liquefied petroleum gases (LPG); compressed natural gas (CNG); liquefied natural gas (LNG); alcohols as alternative fuels, e.g. pure methanol (M100 a "neat" methanol fuel), 85-percent 


\section{The Energy Policy Act Definitions of Alternative and Replacement Fuels}

The Energy Policy Act of 1992 [Section 301 (42 U.S.C. 13211)], defines alternative fuels as:

- methanol, denatured ethanol, and other alcohols; mixtures containing 85 percent or more (or such other percentage but not less than 70 percent as determined by the Secretary of Energy, by rule) by volume of methanol, denatured ethanol, and other alcohols with gasoline or other fuels;

- natural gas;

- liquefied petroleum gases;

- hydrogen;

- coal derived liquid fuels;

- fuels (other than alcohol) derived from biological materials;

- electricity (including electricity from solar energy); and

- any other fuel the Secretary of Energy determines by rule, is substantially not petroleum and would yield substantial energy security benefits and substantial environmental benefits.

Replacement fuels are defined as the portion of any motor fuel that is:

- methanol, ethanol, or other alcohols;

- natural gas;

- liquefied petroleum gases;

- hydrogen;

- coal derived liquid fuels;

- fuels (other than alcohols) derived from biological materials;

- electricity (including electricity from solar energy);

- ethers; or

- any other fuel the Secretary of Energy determines by rule, is substantially not petroleum and would yield substantial energy security benefits and substantial environmental benefits.

These definitions require some clarifications. Liquefied petroleum gases, compressed natural gas, liquefied natural gas, M100, and electricity are sold in "neat" form; that is, without any traditional fuel blended into them. Thus, the fuel consumption values reported for these fuels are identical under both the definitions of alternative and replacement fuels. On the other hand, M85, E85, and E95 are sold as blends; therefore, the replacement fuel consumption values differ from the estimated alternative fuel consumption values. The portion of M85 which is solely methanol is the replacement fuel. For example, a gallon of the alternative fuel M85 contains 0.85 gallons of methanol and 0.15 gallons of gasoline. The replacement fuel portion of this fuel blend would be 0.85 gallons of methanol. To avoid confusion, this publication presents only alternative fuel consumption for LPG, LNG, M85, M100, E85, E95, and electricity. Oxygenates, the most important replacement fuels, are presented separately.

alcohol/15-percent gasoline mixtures (E85 and M85), and 95-percent ethanol/5-percent gasoline mixtures (E95); electricity; methyl tertiary butyl ether (MTBE); ethanol used as a replacement fuel; and other oxygenates. Information on other fuels, such as hydrogen and biodiesel, will be included in later reports as those fuels become more widely used. In addition to national totals, this report presents data for the four U.S. Census Regions: Northeast, South, Midwest, and West (Appendix A). Census Region information provides a broad picture of where
AFV's are located. The majority of AFV's, however, are clustered within specific areas of those regions. The EIA plans to present more regional detail in future reports as survey data become available.

\section{Data Sources and Quality}

The information reported represents a compilation of the most current available information on AFV's and alternative and replacement fuels. However, the 
extent and reliability of certain information are limited because of the embryonic state of alternative transportation fuels markets, regulatory programs, and associated data collection efforts. The quality of the data presented in this report is discussed in Appendix $B$.

Estimates in this report are based on data and information collected from a variety of sources, including Federal agencies, State and local government offices, trade associations, and other private organizations. Energy Information Administration survey data have been used where available. The data estimation methods employed for this report vary by fuel type and ownership category (Federal Government, State and local government fleets, and privately owned AFV's).

There are some differences between the AFV inventories reported in the ATTF Overview and the Alternative to Traditional Transportation Fuels 1993. For a given AFV fuel type, the different estimates in these two publications are a function of a change in industry outlook, a change in data collection methodology, or a combination of both. These differences are also reflected in the fuel consumption estimates since AFV counts are used in the consumption calculation.

The EIA, given additional data collection authority under the EPACT, is in the process of creating both expanded and new data collection programs on AFV's and replacement fuels. For example, in 1994 the EIA created a new survey and modified existing ones to obtain AFV information from the fleets of energy suppliers. The new survey, Form EIA-885, "Propane Provider Fleet Survey," is used to collect fleet vehicle information from companies that conduct bulk deliveries of propane to residential and commercial consumers. Annual statistics on fleet size, vehicle quantities by vehicle and fuel type, refueling facility ownership, vehicle retirements, vehicle costs, fuel consumption, and average vehicle miles traveled per day will be collected once every one-to-three years beginning in 1994. The EIA modified two existing surveys to collect similar fleet information for other fuels. The Form EIA-861, "Annual Electric Utility Report," and the Form EIA176, "Annual Report of Natural Gas and Supplemental Gas Supply and Disposition," collect information about the fleets of electric utilities and natural gas suppliers, respectively. Data from these efforts are expected to be reported in Alternatives to Traditional Transportation Fuels 1994.

The EIA is also developing new surveys to acquire annual historical and projected information mandated by Section 503 of the EPACT. On May 23, 1994, the EIA published a Federal Register Notice announcing the new survey Form EIA-886, "Alternative Fuel Vehicle Suppliers' Annual Report," and invited interested parties to comment on the proposed form, instructions, and definitions. The Form EIA-886, directed at vehicle manufacturers and companies that perform conversions, will be used to request data on AFV's made available on a calendaryear basis. Data collection is proposed to start in early 1995 for calendar year 1994. Another survey under consideration would be used to request the stock of AFV's in use, the quantity of replacement fuels supplied, and other fuel supply data sufficient to estimate the emissions of greenhouse gases. (The EIA is also evaluating an alternative approach that would utilize modifications to existing EIA surveys.) Information from these surveys will be used to support subsequent annual editions of this report.

\section{Contents of Report}

Chapter 2 presents the estimated number of AFV's in use in the United States for 1992, 1993, and 1995. Chapter 3 covers the consumption of alternative and replacement fuels. Chapter 4 discusses greenhouse gas emissions resulting from the alternative and replacement fuel use across the entire fuel cycle. This chapter also presents preliminary findings about emissions and the key elements needed to estimate greenhouse gas emissions. ${ }^{3}$ However, the EIA's emissions analysis to date cannot provide definitive estimates of the levels of greenhouse gas emissions resulting from the current and projected consumption of alternative fuels. Appendix A shows a map displaying U.S. Census Regions; Appendix B contains details on data estimation methods, quality, and sources; Appendix $C$ discusses the greenhouse effect; Appendix D discusses fuel cycle and energy efficiency considerations; Appendix $\mathrm{E}$ discusses biomass land-use impacts on greenhouse gases; and Appendix $F$ is a directory of training centers, original equipment manufacturers, and converters. 


\section{Notes}

${ }^{1}$ Oak Ridge National Laboratory, Transportation Energy Data Book: Edition 14, ORNL-6798 (Oak Ridge, TN, May 1994), pp. 2-12, 2-13.

${ }^{2} \mathrm{~A}$ transportation fuel cycle begins with resource recovery and ends with vehicle fuel consumption (Appendix D).

${ }^{3}$ An explanation of the fuel cycle, the effects of fuel cycle energy efficiency, and emissions factor estimates are provided in Appendix D. The ATTF Overview report contains additional detailed information on these topics. 


\section{Alternative Fueled Vehicle Inventory}

\section{Background}

Alternative fueled vehicles (AFV's) today represent a small share of the vehicles in the United States. Significant market growth is expected to occur within the next several years, driven by government concerns about air quality and dependence on foreign oil.

Alternative fueled vehicles are predominantly utilized in private sector fleets. Private entities maintain AFV's for research and development, demonstration, and general use. Within the government sector, the presence of AFV's is small but expected to increase dramatically in the next few years. Federal programs are attempting to overcome obstacles to AFV market growth by funding the incremental cost of vehicle purchases and conversions. The Federal Government is also coordinating efforts with State, local, and private entities to permit the development of a self-sustaining alternative refueling infrastructure.

Although government programs are mainly directed at vehicles purchased or leased by government agencies, the Clean Cities Program was initiated by the Department of Energy (DOE) to develop AFV markets in urban areas and foster cooperation between stakeholders in both the public and private sectors. The program establishes city/Federal part-

\section{A History of Legislation Affecting Alternative Fuels}

In 1988, the Alternative Motor Fuels Act (AMFA) directed Federal agencies to administer programs that would encourage the development of alternative transportation fuels (ATF's) and the production of alternative fueled vehicles (AFV's). The Alternative Motor Fuels Act provided financial support for research, development, and demonstration of vehicles and fuels; especially with Federal fleets; The Clean Air Act Amendments of 1990 (CAAA), which reguläted böth transportation fuel content and allowable air emissions from transportation fuels, raised speculation that alternative fuels could better meet stîict environmental standards than traditional fuels. However, nearly all the CAAA programs set numerical emission standards rather than requiring the use of alternative fuels. Any fuel, including gasoline, which can meet these standards will qualify.

In 1992, the Energy Policy Act of 1992 (EPACT) established a national goal of replacement furels displacing 30 percent of projected U.S. motor fuels by 2010; at least half of the displacement should be generated from domestic sources:" The EPACT also requires purchases of AFV's by certain fleets and provides tax incentives for the purchase of AFV's and construction of ATF refueling stations. The EPACT mandates the development of a replacement fuel supply and demand program designed to ensure the availability of replacement fuels and fuel delivery systems. The EPACT also gave the Department of Energy authority to seek voluntary replacement fuel supply commitments from fuel suppliers. To reinforce the EPACT, Executive Order 12844 (April 21, 1993) called for Federal action to promote the development and manufacture of AFV's, and provide infrastructure to suppoit large numbers of privately owned AFV's. It also established goals to exceed EPACT Federal AFV purchase requirements by 50 percent.

At the same time that Federal legislation was encouraging AFF development, State and local governments also began to consider ATF programs primarily to help them meet clean air-standards promulgated in the CAAA. These programs take the form of fuel excise and sales tax exemptions; investment tax credits; community grant programs; research and development funding programs; véhicle conversion rebates; fuel use mandates for state-owned or leased vehicies; and in the case of compressed natural gas (CNG), deregulation of end-user sales. (Ten States have enacted laws deregulating CNG sold to end users as a transportation fuel,) As of 1994 , at least 13 states have variations of purchase requirements for AFV's in State: fleets, and at least 20 states have finaricial incentive programs (mostly tax feductions or exemptions for vehicles andfor fuels). 
nerships to promote AFV acquisition and the development of an ATF refueling infrastructure, while recognizing the unique environmental and economic situations facing each city. Eighteen metropolitan areas have joined the DOE Clean Cities Program, thus far. ${ }^{1}$ By the end of 1994, an additional 17 cities are expected to be participating, exceeding the goal of 25 cities which DOE set in 1993.

\section{Types of Alternative Transportation Fuels and Alternative Fueled Vehicles}

Alternative fueled vehicles may be classified according to fuel type and fuel system configuration (Figure 1). The major alternative transportation fuels in use today are liquefied petroleum gases (LPG), natural gas (compressed and liquefied), alcohol (methanol, ethanol), and electricity.

Vehicles designed to operate on LPG (mainly propane) have the largest market share of all the AFV's. The majority of LPG-fueled vehicles are light-duty ones that have been converted from gasoline or diesel, and are operated by private industry.

Natural gas vehicles, which represent the secondlargest type of AFV, range from cars, trucks, and buses to refuse haulers. These vehicles operate on either compressed natural gas (CNG) or liquefied natural gas (LNG), with the majority of vehicles running on CNG. Most of the CNG vehicles in operation today are conversions from conventionally-fueled vehicles.

Alcohol can be consumed by vehicles in several ways: in pure form, such as neat methanol; in fuel mixtures with conventional fuel where alcohol represents at least 85 percent of the fuel mixture; and as fuel extenders, oxygen enhancers, and octane boosters in conventional fuels, where the quantity of alcohol typically represents 10 percent or less of the fuel mixture.

Electric vehicles are primarily used as delivery vehicles, passenger cars, and taxicabs, which operate over limited ranges. At present, battery characteristics that limit the electric vehicle's driving range are one barrier to the large production runs that would make electric vehicles more cost competitive. To overcome this barrier, the U.S. Advanced Battery Consortium (USABC) was formed in 1991 to accelerate advanced battery research programs. Participants in the USABC include the "Big Three" auto manufacturers (General Motors, Ford, and Chrysler), the DOE, the Electric Power Research Institute, and the electric utility industry.

Fuel system configuration pertains to the method of fuel storage and delivery. The primary AFV's fall into the following four configurations: dedicated, bi-fueled, dual-fueled, and flexible-fueled (Figure 1). ${ }^{2} \quad$ Energy Information Administration (EIA) surveys that are under consideration will request data by vehicle fuel type and configuration. These data will be presented in subsequent editions of Alternatives to Traditional Transportation Fuels.

Dedicated vehicles are built to run exclusively on one alternative fuel or energy source (such as electricity from batteries) and, as a result, require fewer components. This design strategy also permits the engine/fuel/emission systems to be optimized for the alternative fuel.

Bi-fueled vehicles are capable of operating on either an alternative fuel or a conventional fuel (gasoline or diesel), but not on a mixture of the fuels. Vehicles of this type generally have an automatic or

\section{Figure 1. Alternative Fueled Vehicle} Configurations and Fuel Types
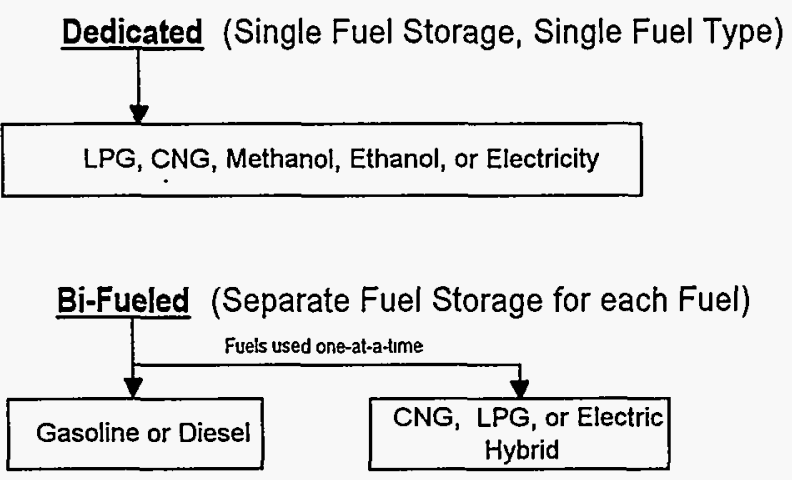

Dual-Fueled (Separate Fuel Storage for eàch Fuel)
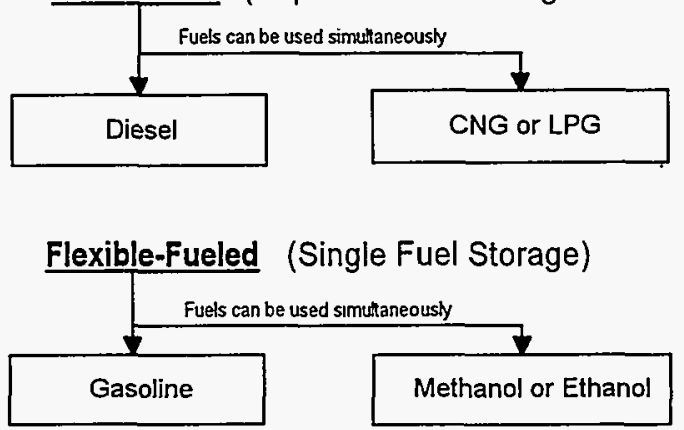

Source: Energy Information Administration, Office of Coal, Nuclear, Electric, and Alternate Fuels. 
manual switch that permits operation on either fuel. Each fuel is stored in a separate tank. Most bifueled vehicles operate on a combination of gasoline and either natural gas or LPG. Electric bi-fueled vehicles are commonly referred to as electric hybrids. Hybrids are vehicles that contain an onboard internal combustion engine that generates electricity to supplement the power in the batteries. Fuel cells, solar collectors or gas turbines could also be used in a hybrid configuration to generate electricity.

Dual-fueled vehicles also have two fuel systems but, unlike bi-fueled vehicles, both fuels can be burned simultaneously in the engine combustion chamber. The majority of dual-fueled vehicles operate on CNG and diesel.

Flexible-fueled, or variable-fueled, vehicles have only one fuel tank, which contains mixtures of the alternative fuel and gasoline. A sensor determines the percentage of the alternative fuel relative to gasoline and adjusts engine operating characteristics automatically. Until the infrastructure for methanol and ethanol fuels becomes more developed, flexiblefueled vehicles will be preferred by consumers for alcohol fuel use because they can operate on gasoline exclusively if alcohol fuels are unavailable.

\section{Production of Alternative Fueled Vehicles}

Alternative fueled vehicles can be produced by original equipment manufacturers (OEM's) or converted from conventionally-fueled vehicles. As of November 1994, the EIA had identified 60 OEM's and nearly 1,000 companies that perform conversions. Appendix $\mathrm{E}$ contains a list of conversion companies, OEMs, and training facilities. There are two types of conversions: after-market conversions (retrofitting) and OEM conversions. In an aftermarket conversion a conventionally-fueled vehicle is modified after its first use or sale with equipment that enables it to operate on an alternative fuel. Such conversions are performed by commercial companies; trained personnel may perform in-house conversions. In an OEM conversion, a vehicle is modified to operate on an alternative fuel prior to its first use or sale. OEM conversions are often performed by a conversion company under agreement with an OEM. Warranty coverage is either handled by the OEM or jointly by the OEM and the conversion company.

Original equipment manufacturers target the fleet market, with production schedules typically based on special customer orders accumulated over a period of time. Most AFV acquisitions are arranged directly with the OEM fleet departments, although orders can be placed through dealerships as well. In contrast, conventional vehicles are produced in large batches at one time, with most vehicles purchased by dealerships for retail sale to the public.

\section{Estimated Vehicle Stocks in 1992, 1993, and 1995}

All AFV stocks are expected to increase from 1993 to 1995 , except for vehicles fueled by M100, which are expected to remain constant (Table 1). The most significant increases are expected to be for AFV's fueled by CNG (up by at least 60,000 vehicles) and LPG (up by almost 30,000 vehicles). For the same period, the fastest estimated growth rates in AFV stocks will be those vehicles fueled by CNG (185 percent), M85 (95 percent) and E85 (88 percent).

\section{Estimation Methods and Data Sources}

The methods employed for estimating AFV stocks in this report vary by fuel type and ownership category (Federal, State and local government, and private). Vehicle information for Federal Government fleets was obtained from the General Services Administration (GSA) and individual Federal agencies. A summary of the estimation methods and sources for State and local government and private vehicles is presented in Table 2. Detailed descriptions of data estimation methods and quality are presented in Appendix B.

\section{Alternative Fueled Vehicles by Fuel Type, Ownership, and Weight Class, 1992}

At least 251,000 AFV's were in use in 1992, with light- and heavy-duty vehicles representing 81 and 19 percent, respectively (Table 3 ). An analysis of the vehicles by fuel type reveals the three largest contributors to be LPG, CNG, and M85.

A minimum of 221,000 AFV's (88 percent of the total AFV count) were fueled by LPG, of which at least 177,000 were light-duty vehicles. The number of LPG-fueled vehicles is considered to be a minimum estimate because the consumption data from which the State and local government, and privately owned vehicle counts were derived are believed to underreport LPG road use (Appendix B). Compressed natural gas-fueled vehicles represented the second largest type of AFV's in 1992, followed by M85-fueled vehicles. Approximately 23,000 AFV's 
Table 1. Estimated Alternative Fueled Vehicles in Use by Fuel, 1992, 1993 and 1995

\begin{tabular}{|c|c|c|c|}
\hline Fuel & 1992 & 1993 & 1995 \\
\hline $\operatorname{LPG}^{1} \ldots \ldots \ldots \ldots \ldots \ldots$ & $>221,000$ & $>269,000$ & $>299,000$ \\
\hline CNG $\ldots \ldots \ldots \ldots \ldots \ldots$ & 23,191 & 32,714 & 93,186 \\
\hline$\ldots \ldots \ldots \ldots \ldots$ & 90 & 299 & 447 \\
\hline$M 85 \ldots \ldots \ldots \ldots \ldots \ldots$ & 4,850 & 10,263 & 20,040 \\
\hline$M 100 \ldots \ldots \ldots \ldots \ldots$ & 404 & 414 & 413 \\
\hline E85 $\ldots \ldots \ldots \ldots \ldots \ldots \ldots$ & 172 & 441 & 828 \\
\hline E95 $\ldots \ldots \ldots \ldots \ldots \ldots$ & 38 & 27 & 33 \\
\hline Electricity $\ldots \ldots \ldots \ldots \ldots$ & 1,725 & 1,847 & 2,250 \\
\hline Unknown $\ldots \ldots \ldots \ldots \ldots$ & 0 & 140 & 2,429 \\
\hline All Fuels $\ldots \ldots \ldots \ldots \ldots$ & $>251,470$ & $>315,145$ & $>418,626$ \\
\hline
\end{tabular}

' Values represent lower bound estimates and are rounded to thousands.

Source: Science Applications International Corporation, "Alternative Transportation Fuels and Vehicles Data Development," unpublished final report prepared for the Energy Information Administration, (McLean, VA, August 1994).

were fueled by CNG, and 4,850 AFV's were fueled by M85.

Alcohol-fueled vehicles utilizing M85, M100, E85, and E95 totaled slightly less than 5,500. Ninetyseven percent of the 4,850 vehicles fueled by M85 were light duty. There were 404 AFV's fueled by M100, of which 37 were light duty. For ethanol, 172 vehicles were fueled by E85, of which 170 were light duty. E95 fueled 38 vehicles, of which 10 were light duty.

Electric vehicles totaled 1,725 , or less than 1 percent of the total AFV's in use. Of this total, 1,715 were light-duty vehicles. Finally, there were 90 AFV's fueled by LNG, of which only 5 were light duty.

Light-duty AFV's accounted for at least 204,000 (roughly 0.12 percent) of the 177 million light-duty vehicles registered in $1992 .^{3}$ The small market presence of this developing technology has been due to factors such as the focusing of past transportation fuel development efforts on traditional fuels, the high cost of producing and converting some AFV's, the lack of an infrastructure for refueling and maintaining some vehicle types, and the short driving range of some AFV's. Until now, the market for AFV's has primarily been limited to fleets where centralized refueling can occur.

\section{Federal Vehicles}

In 1992, the Federal Government operated almost 3,400 AFV's (about 1 percent of the total AFV count). Of this total, approximately 2,600 (77 percent) were fueled by M85. Almost 700 Federal AFV's (21 percent) were CNG-fueled vehicles. The remaining 2 percent consisted of the following fuel types: electricity ( 35 vehicles), ethanol (25 E85-fueled vehicles), and LPG (19 vehicles). No Federal AFV's were fueled by LNG, M100, or E95. Furthermore, all of the AFV's owned and/or operated by the Federal Government were light-duty vehicles.

\section{State and Local Vehicles}

State and local governments operated a minimum of 18,000 AFV's (7 percent of the total AFV count) in 1992. The primary fuel type for the State and local government sector was LPG, with an estimated count of at least $11,000 \mathrm{AFV}$ 's, or 61 percent of the State and local total. Over 80 percent of the LPGfueled vehicles in the State and local government sector were light duty. Compressed natural gasfueled vehicles, totaling almost 4,700 , made up the next largest group of AFV's, representing 26 percent of the total State and local AFV's. The distribution of CNG-fueled light- and heavy-duty vehicles was 79 and 21 percent, respectively. Alcohol-fueled vehi- 
Table 2. Estimation Methods and Sources for Privately Owned and State and Local Government Vehicle Counts

\begin{tabular}{|c|c|c|}
\hline Fuel/Year & Estimation Method & Data Sources \\
\hline \multicolumn{3}{|l|}{ Liquefied Petroleum Gases } \\
\hline $1992,1993 \ldots \ldots$ & $\begin{array}{l}\text { Enumeration of AFVs in } 17 \text { States for which } \\
\text { motor fuel tax information is available; Imputation } \\
\text { to } 33 \text { States with no tax information. }\end{array}$ & $\begin{array}{l}\text { State departments of revenue; State energy offic- } \\
\text { es; Energy Information Administration, State } \\
\text { Energy Data Report, (1993). }\end{array}$ \\
\hline $1995 \ldots \ldots \ldots$ & $\begin{array}{l}\text { Derived annual rates of growth in LPG vehicles } \\
\text { applied to base years. }\end{array}$ & $\begin{array}{l}\text { State departments of revenue; State energy } \\
\text { offices; National Propane Gas Association; vehicle } \\
\text { converters. }\end{array}$ \\
\hline \multicolumn{3}{|l|}{ Compressed Natural Gas } \\
\hline $1992 \ldots \ldots \ldots$ & $\begin{array}{l}\text { Independent survey of gas suppliers conducted in } \\
1993 ; \text { Non-Federal counts derived by subtracting } \\
\text { State/Federal vehicles. }\end{array}$ & $\begin{array}{l}\text { Survey responses from } 160 \text { gas suppliers and } \\
\text { refueling station owners; Federal data from NREL } \\
\text { database. }\end{array}$ \\
\hline $1993,1995 \ldots \ldots \ldots$ & $\begin{array}{l}1994 \text { update of } 1993 \text { survey (a sample of the } \\
1993 \text { survey respondents was used); respondents } \\
\text { asked to provide year-end } 1993 \text { and } 1995 \text { counts. }\end{array}$ & $\begin{array}{l}\text { Same as above except for the use of a limited } \\
\text { sample of gas distributors. }\end{array}$ \\
\hline \multicolumn{3}{|l|}{ Liquetied Natural Gas } \\
\hline $1992,1993 \ldots \ldots$ & $\begin{array}{l}\text { Enumeration of reported purchases of LNG transit } \\
\text { buses and other vehicles. }\end{array}$ & $\begin{array}{l}\text { Independent study of transit bus and on-road } \\
\text { operations. }\end{array}$ \\
\hline $1995 \ldots \ldots \ldots$ & Same as above. & Same as above. \\
\hline \multicolumn{3}{|l|}{ Methanol/Ethanol Fuels } \\
\hline $1992,1993,1995 \ldots$ & $\begin{array}{l}\text { Independent survey of State organizations knowl- } \\
\text { edgeable on ethanol/methanol fuels and vehicles. } \\
\text { Surveys requested total AFV counts for each } \\
\text { State; Federal vehicles were subtracted from } \\
\text { State totals. }\end{array}$ & $\begin{array}{l}\text { State energy offices and other agencies; fuel } \\
\text { supply companies; corn growers associations; } \\
\text { vehicle and engine manufacturers. }\end{array}$ \\
\hline \multicolumn{3}{|l|}{ Electricity } \\
\hline $1992,1993,1995 \ldots$ & $\begin{array}{l}\text { Independent survey of electric vehicle owner } \\
\text { associations, electric utilities, and State agencies. }\end{array}$ & $\begin{array}{l}\text { Electric Automobile Association (State and local } \\
\text { chapters); State energy offices, electric utilities in } \\
\text { states with a large number of EVs; vehicle } \\
\text { converters. }\end{array}$ \\
\hline
\end{tabular}

Source: Sclence Applications International Corporation, "Alternative Transportation Fuels and Vehicles Data Development," unpublished final report prepared for the Energy Information Administration, (McLean, VA, August 1994).

cles accounted for 12 percent of the total State and local inventory, or 2,124 AFV's. Electric vehicles contributed the remaining 1 percent (about 100 vehicles, of which 9 were heavy duty).

\section{Privately Owned Vehicles}

The private sector owned and/or operated an estimated minimum of $230,000 \mathrm{AFV}$ 's, or about 92 percent of total AFV's, in 1992. The private sector had an AFV weight class distribution of approximately 81 percent light duty and 19 percent heavy duty. The two major types of AFV's used by the private sector were LPG- and CNG-fueled vehicles.
At least 210,000 privately owned vehicles were fueled by LPG ( 80 percent light duty), while about 18,000 were fueled by CNG ( 93 percent light duty). Privately owned, alcohol-fueled vehicles numbered 725. There were 677 vehicles fueled by M85, of which 3 were heavy duty, and there were 6 vehicles fueled by M100, all heavy duty. Twenty-nine privately owned AFV's were fueled by E85, of which only a single vehicle was heavy duty. E95 fueled 13 vehicles, of which 9 were light duty. The private sector accounted for about 92 percent $(1,589)$ of all electric vehicles in the Nation. With one exception, all of the privately owned electric vehicles were light duty. 
Table 3. Estimated Alternative Fueled Vehicles in Use by Fuel, Ownership, and Weight Class, 1992

\begin{tabular}{|c|c|c|c|c|c|c|c|c|c|}
\hline \multirow[b]{2}{*}{ Fuel } & \multicolumn{2}{|c|}{$\begin{array}{c}\text { Federal } \\
\text { Government }\end{array}$} & \multicolumn{2}{|c|}{$\begin{array}{c}\text { State and Local } \\
\text { Government }\end{array}$} & \multicolumn{2}{|c|}{ Private } & \multicolumn{3}{|c|}{ Total } \\
\hline & $\begin{array}{l}\text { Light } \\
\text { Duty' }\end{array}$ & $\begin{array}{l}\text { Heavy } \\
\text { Duty }\end{array}$ & $\begin{array}{l}\text { Light } \\
\text { Duty' }\end{array}$ & $\begin{array}{l}\text { Heavy } \\
\text { Duty }\end{array}$ & $\begin{array}{l}\text { Light } \\
\text { Duty' }\end{array}$ & $\begin{array}{l}\text { Heavy } \\
\text { Duty }\end{array}$ & $\begin{array}{l}\text { Light } \\
\text { Duty }\end{array}$ & $\begin{array}{l}\text { Heavy } \\
\text { Duty }\end{array}$ & Total \\
\hline $\mathrm{LPG}^{2}$ & 19 & 0 & $>9,000$ & $>2,000$ & $>168,000$ & $>42,000$ & $>177,000$ & $>44,000$ & $>221,000$ \\
\hline CNG & 691 & 0 & 3,665 & 993 & 16,517 & 1,325 & 20,873 & 2,318 & 23,191 \\
\hline LNG & 0 & 0 & 2 & 69 & 3 & 16 & 5 & 85 & 90 \\
\hline M85 & 2,590 & 0 & 1,452 & 131 & 674 & 3 & 4,716 & 134 & 4,850 \\
\hline M100 & 0 & 0 & 37 & 361 & 0 & 6 & 37 & 367 & 404 \\
\hline E85 & 25 & 0 & 117 & 1 & 28 & 1 & 170 & 2 & 172 \\
\hline E95 & 0 & 0 & 1 & 24 & 9 & 4 & 10 & 28 & 38 \\
\hline Electricity .. & 35 & 0 & 92 & 9 & 1,588 & 1 & 1,715 & 10 & 1,725 \\
\hline Non-LPG Total & 3,341 & 1 & 5,366 & 1,588 & 18,819 & 1,356 & 27,526 & 2,944 & 30,470 \\
\hline All Fuels $\ldots$ & 3,360 & 0 & $>14,366$ & $>3,588$ & $>186,819$ & $>43,356$ & $>204,526$ & $>46,944$ & $>251,470$ \\
\hline
\end{tabular}

'Weight classes based on Environmental Protection Agency definitions: Light Duty $\leq 8,500$ pounds Gross Vehicle Weight; Heavy Duty $>8,500$ pounds.

${ }^{2}$ Non-Federal values represent lower bound estimates and are rounded to thousands.

Note: $\cdot$ Fuel terms are defined in the Glossary. LPG = Liquefied Petroleum Gases; CNG = Compressed Natural Gas; LNG = Liquefied Natural Gas; $M 85=$ mixture of $85 \%$ Methanol, $15 \%$ Gasoline; M100 = Neat Methanol; E85 = mixture of $85 \%$ Ethanol, $15 \%$ Gasoline; E95 $=$ mixture of $95 \%$ Ethanol, 5\% Gasoline.

Sources: Federal Government General Services Administration, Interagency Fleet Management System and Automotive Commodity Center; Federal agencies. State and Local Govemment and Private: Science Applications International Corporation, "Alternative Transportation Fuels and Vehicles Data Development," unpublished final report prepared for the Energy Information Administration, (McLean, VA, August 1994).

\section{Alternative Fueled Vehicles by Fuel Type, Ownership, and Weight Class, 1993 and 1995}

Information identical to that presented for 1992 is shown for 1993 and 1995 (Tables 4 and 5). In percentage terms, Federally owned AFV's are expected to show the greatest increase between 1992 and 1995. In terms of vehicle count, privately owned AFV's will increase the most, from at least 230,000 to over 349,000 . Overall, the light-/heavyduty vehicle ratio between 1992 and 1995 is expected to decrease, with most of the rise in heavy-duty market share occurring in 1993. Compressed natural gas light-duty vehicles will dominate the increase in government-owned vehicles, while LPG will account for over 60 percent of the gain in privately owned AFV's. Although most electric vehicles listed in this report are battery-powered, the electric vehicle inventory for 1995 includes at least one hydrogen peroxide fuel cell-powered vehicle, six solar electric, and an undetermined number of hybrid vehicles.

\section{Regional Distribution of AFV's for 1993 and 1995}

Vehicle count information for private, and State and local governments is presented by U.S. Census Region for 1993 and 1995 (Tables 6 and 7). ${ }^{4}$ The U.S. Census Regions are defined in the Glossary and presented on a map in Appendix A. In 1993, the South had the largest concentration of AFV's (34 percent), followed by the West ( 31 percent). The reason for the high concentration of vehicles in the South is partly due to that Region's larger number of constituent states (17), and partly due to the large numbers of LPG- and CNG-fueled vehicles in Texas. Texas provides a good example of a State that is strongly active in promoting AFV's. State laws and regulations, implemented by the Texas Land and Railroad Commissions, have been strong factors behind the growth of AFV's, which was the highest of any State in 1993. California, the State with the largest AFV population, is the major contributor to the high concentration of AFV's in the West. 
Table 4. Estimated Alternative Fueled Vehicles in Use by Fuel, Ownership, and Weight Class, 1993

\begin{tabular}{|c|c|c|c|c|c|c|c|c|c|}
\hline \multirow[b]{2}{*}{ Fuel } & \multicolumn{2}{|c|}{$\begin{array}{c}\text { Federal } \\
\text { Government }\end{array}$} & \multicolumn{2}{|c|}{$\begin{array}{c}\text { State and Local } \\
\text { Government }\end{array}$} & \multicolumn{2}{|c|}{ Private } & \multicolumn{3}{|c|}{ Total } \\
\hline & $\begin{array}{l}\text { Light } \\
\text { Duty }\end{array}$ & $\begin{array}{l}\text { Heavy } \\
\text { Duty }^{1}\end{array}$ & $\begin{array}{l}\text { Light } \\
\text { Duty }\end{array}$ & $\begin{array}{l}\text { Heavy } \\
\text { Duty }\end{array}$ & $\begin{array}{l}\text { Light } \\
\text { Duty }{ }^{1}\end{array}$ & $\begin{array}{l}\text { Heavy } \\
\text { Duty }\end{array}$ & Light Duty ${ }^{1}$ & $\begin{array}{l}\text { Heavy } \\
\text { Duty }\end{array}$ & Total \\
\hline $\mathrm{LPG}^{2} \quad \ldots \ldots$ & 32 & 0 & $>10,000$ & $>3,000$ & $>192,000$ & $>64,000$ & $>202,000$ & $>67,000$ & $>269,000$ \\
\hline CNG $\ldots \ldots$ & 3,090 & 0 & 8,692 & 2,281 & 16,932 & 1,719 & 28,714 & 4,000 & 32,714 \\
\hline LNG $\ldots \ldots$ & 0 & 0 & 29 & 265 & 2 & 3 & 31 & 268 & 299 \\
\hline M85 & 5,518 & 0 & 1,900 & 108 & 2,737 & 0 & 10,155 & 108 & 10,263 \\
\hline M100 $\ldots \ldots$ & 0 & 0 & 0 & 412 & 0 & 2 & 0 & 414 & 414 \\
\hline E85 $\ldots \ldots$ & 114 & 0 & 273 & 2 & 52 & 0 & 439 & 2 & 441 \\
\hline E95 & 0 & 0 & 1 & 18 & 4 & 4 & 5 & 22 & 27 \\
\hline Electricity & 36 & 0 & 135 & 19 & 1,657 & 0 & 1,828 & 19 & 1,847 \\
\hline Unknown ${ }^{3} \ldots$ & 140 & 0 & 0 & 0 & 0 & 0 & 140 & 0 & 140 \\
\hline Non-LPG Total & 8,898 & 0 & 11,030 & 3,105 & 21,384 & 1,728 & 41,312 & 4,833 & 46,145 \\
\hline All Fuels & 8,930 & 0 & $>21,030$ & $>6,105$ & $>213,384$ & $>65,728$ & $>243,312$ & $>71,833$ & $>315,145$ \\
\hline
\end{tabular}

'Weight classes based on Environmental Protection Agency definitions: Light Duty $\leq 8,500$ pounds Gross Vehicle Weight; Heavy Duty $>8,500$ pounds.

${ }^{2}$ Non-Federal values represent lower bound estimates and are rounded to thousands.

' Cannot be identified by fuel type, therefore Non-LPG totals may include some unidentified LPG vehicles.

Note: $\cdot$ Fuel terms are defined in the Glossary. LPG $=$ Liquefied Petroleum Gases; CNG = Compressed Natural Gas; LNG $=$ Liquefied Natural Gas; M85 = mixture of $85 \%$ Methanol, $15 \%$ Gasoline; M100 = Neat Methanol; E85 = mixture of $85 \%$ Ethanol, $15 \%$ Gasoline; E95 = mixture of $95 \%$ Ethanol, $5 \%$ Gasoline.

Sources: Federal Govemment: General Services Administration, Interagency Fleet Management System and Automotive Commodity Center; Federal agencies. State and Local Govemment and Private: Science Applications International Corporation, "Alternative Transportation Fuels and Vehicles Data Development," unpublished final report prepared for the Energy Information Administration, (McLean, VA, August 1994).

Vehicles fueled with LPG were fairly evenly distributed between the South, the Midwest, and the West. Of the total number of private, State and local government CNG-fueled vehicles, 68 percent were located in the South and the West. Nearly all of the M85- and M100-fueled vehicles were in the West. The largest concentration of ethanol-fueled vehicles was in the Midwest, which accounts for 92 percent of the national total (the major ethanol producing areas are located in the Midwest). The second largest concentration of ethanol-fueled vehicles was in the West, which accounted for 8 percent of the E85-fueled vehicles. Electric vehicles accounted for less than 1 percent of the national total, with the majority located in California. Almost 98 percent of all LNG-fueled vehicles were located in the South, with the most operating in Texas.

The regional distribution of AFV's in 1995 is essentially unchanged from 1993. Liquefied natural gas- fueled vehicles will gain in the South, while E85 and electricity increases their market share in the West. The Northeast and South will gain market share in electric vehicles.

\section{Trends in Alternative Fueled Vehicle Inven- tories, 1992 to 1995}

\section{Liquefied Petroleum Gas (LPG) Vehicles}

The number of LPG-fueled vehicles is expected to increase by more than 11 percent from 1993 to 1995. In contrast to most other AFV's, the expansion of LPG-fueled vehicle counts is due to private sector commercial fleet purchases. In many cases, these acquisitions are encouraged by State government tax incentives. Other reasons for expansion include ease of engine conversion to and from LPG, widespread fuel availability, competitive prices, support 
Table 5. Projected Alternative Fueled Vehicles in Use by Fuel, Ownership, and Weight Class, 1995

\begin{tabular}{|c|c|c|c|c|c|c|c|c|c|}
\hline \multirow[b]{2}{*}{ Fuel } & \multicolumn{2}{|c|}{$\begin{array}{c}\text { Federal } \\
\text { Government }\end{array}$} & \multicolumn{2}{|c|}{$\begin{array}{c}\begin{array}{c}\text { State and Local } \\
\text { Government }\end{array} \\
\end{array}$} & \multicolumn{2}{|c|}{ Private } & \multicolumn{3}{|c|}{ Total } \\
\hline & $\begin{array}{l}\text { Light } \\
\text { Duty }\end{array}$ & $\begin{array}{l}\text { Heavy } \\
\text { Duty }^{1}\end{array}$ & $\begin{array}{l}\text { Light } \\
\text { Duty }\end{array}$ & $\begin{array}{l}\text { Heavy } \\
\text { Duty }\end{array}$ & $\begin{array}{l}\text { Light } \\
\text { Duty' }\end{array}$ & $\begin{array}{l}\text { Heavy } \\
\text { Duty }\end{array}$ & $\begin{array}{l}\text { Light } \\
\text { Duty }\end{array}$ & $\begin{array}{l}\text { Heavy } \\
\text { Duty }\end{array}$ & Total \\
\hline $\mathrm{LPG}^{2} \quad \ldots$ & 328 & & $>11,000$ & $>4,000$ & $>213,000$ & $>71,000$ & $>224,000$ & $>75,000$ & $>299,000$ \\
\hline CNG & 8,460 & 25 & 32,576 & 6,010 & 41,124 & 4,991 & 82,160 & 11,026 & 93,186 \\
\hline LNG & 8 & 0 & 50 & 381 & 2 & 6 & 60 & 387 & 447 \\
\hline M85 & 9,540 & 24 & 2,720 & 109 & 7,647 & 0 & 19,907 & 133 & 20,040 \\
\hline M100 & 0 & 0 & 0 & 412 & 0 & 1 & 0 & 413 & 413 \\
\hline E85 & 321 & 0 & 451 & 2 & 54 & 0 & 826 & 2 & 828 \\
\hline E95 & 0 & 0 & 1 & 24 & 4 & 4 & 5 & 28 & 33 \\
\hline Electricity & 35 & 18 & 273 & 67 & 1,857 & 0 & 2,165 & 85 & 2,250 \\
\hline Unknown ${ }^{3}$ & 2,429 & 0 & 0 & 0 & 0 & 0 & 2,429 & 0 & 2,429 \\
\hline Non-LPG Total ${ }^{3}$ & 20,793 & 67 & 36,071 & 7,005 & 50,688 & 5,002 & 107,552 & 12,074 & 119,626 \\
\hline All Fuels $\ldots \ldots$ & 21,121 & 70 & $>47,071$ & $>11,005$ & $>263,688$ & $>76,002$ & $>331,552$ & $>87,074$ & $>418,626$ \\
\hline
\end{tabular}

${ }^{1}$ Weight classes based on Environmental Protection Agency definitions: Light Duty $\leq 8,500$ pounds Gross Vehicle Weight; Heavy Duty > 8,500 pounds.

${ }^{2}$ Non-Federal values represent lower bound estimates and are rounded to thousands.

${ }^{3}$ Cannot be identified by fuel type, therefore Non-LPG totals may include some unidentified LPG vehicles.

Note: -Fuel terms are defined in the Glossary. LPG = Liquefied Petroleum Gases; CNG = Compressed Natural Gas; $L N G=$ Liquefied Natural Gas; M85 = mixture of $85 \%$ Methanol, $15 \%$ Gasoline; M100 = Neat Methanol; E85 = mixture of $85 \%$ Ethanol, $15 \%$ Gasoline; E95 = mixture of 95\% Ethanol, 5\% Gasoline.

Sources: Federal Govemment: General Services Administration, Interagency Fleet Management System and Automotive Commodity Center; Federal agencies. State and Local Govemment and Private: Science Applications International Corporation, "Alternative Transportation Fuels and Vehicles Data Development," unpublished final report prepared for the Energy Information Administration, (McLean, VA, August 1994).

from large domestic oil companies, and environmental benefits.

\section{Compressed Natural Gas (CNG) Vehicles}

The use of CNG-fueled vehicles increased by about 41 percent from 1992 to 1993 , and is projected to increase at an annual rate of 69 percent between 1993 and 1995. Both light- and heavy-duty weight classes of private, and State and local governmentowned CNG-fueled vehicles will more than double during this period. This impressive growth is a reflection of public and private sector enthusiasm for the fuel, the support of natural gas utilities (e.g., marketing, subsidized fuel prices, sponsorship of demonstration programs), and relatively greater fuel and vehicle availability compared to most other ATF's. However, there are indications that private sector interest in the vehicles has been moderated by recent incidents involving one vehicle model's fuel tank ruptures and the inconclusive results of demonstration programs.

\section{Liquefied Natural Gas (LNG) Vehicles}

From 1993 to 1995, the number of LNG-fueled vehicles in State and local government fleet inventories is expected to increase in all weight classes. The number of vehicles expected to be deployed depends significantly on the activities of a few large transit bus programs. For example, cancellations and acquisition delays by only two transit operators, Seattle Metro and Los Angeles County Metro, have had a significant impact on the market. In the private sector, no market for LNGfueled vehicles exists. Future growth depends on several factors, including increased fuel system reliability, resolution of outstanding safety and maintenance issues, and government subsidies for bus purchases. 
Table 6. Estimated Privately Owned and State and Local Government Alternative Fueled Vehicles in Use by Census Region, 1993

\begin{tabular}{|c|c|c|c|c|c|}
\hline \multirow[b]{2}{*}{ Fuel } & \multicolumn{4}{|c|}{ Percent of U.S. Total } & \multirow[b]{2}{*}{ U.S. Total } \\
\hline & Northeast & South & Midwest & West & \\
\hline$\overline{\mathrm{LPG}}^{1} \quad \ldots \ldots \ldots$ & 11 & 34 & 26 & 29 & $>269,000$ \\
\hline CNG $\ldots \ldots \ldots$ & 15 & 35 & 17 & 33 & 29,624 \\
\hline LNG $\ldots \ldots \ldots \ldots$ & 0 & 98 & 2 & 1 & 299 \\
\hline M85 $\ldots \ldots \ldots \ldots$ & 2 & 1 & 1 & 96 & 4,745 \\
\hline$\ldots \ldots \ldots$ & 2 & 2 & 0 & 96 & 414 \\
\hline E85 $\ldots \ldots \ldots \ldots$ & * & 0 & 92 & 8 & 327 \\
\hline E95 $\ldots \ldots \ldots \ldots$ & 0 & 7 & 93 & 0 & 27 \\
\hline Electricity $\ldots \ldots \ldots$ & 13 & 10 & 3 & 75 & 1,811 \\
\hline All Fuels $\ldots \ldots \ldots$ & 11 & 34 & 25 & 31 & $>306,247$ \\
\hline
\end{tabular}

'U.S. total represents lower bound estimates.

- Less than 0.5 percent rounded to 0 .

Notes: -Components may not add to 100 percent due to rounding. $\cdot F u e l$ terms are defined in the Glossary. LPG $=$ Liquefied Petroleum Gases; CNG = Compressed Natural Gas; LNG = Liquefied Natural Gas; M85 = mixture of 85\% Methanol, 15\% Gasoline; M100 = Neat Methanol; E85 $=$ mixture of $85 \%$ Ethanol, $15 \%$ Gasoline; E95 = mixture of $95 \%$ Ethanol, $5 \%$ Gasoline.

Source: Science Applications International Corporation, "Alternative Transportation Fuels and Vehicles Data Development," unpublished final report prepared for the Energy Information Administration, (McLean, VA, August 1994).

\section{Methanol (M85) Vehicles}

From 1992 to 1995, the number of M85-fueled vehicles is expected to increase at a rapid pace primarily as a result of State incentive programs for private sector fleet users in California, where the majority of these vehicles are located. Most of the anticipated increase in privately owned M85-fueled vehicles for 1995 will be the result of the creation and rapid growth of large corporate fleets, including rental car companies (almost exclusively in California). Out of the 20,040 M85-fueled vehicles expected in 1995, an estimated 7,647 will be owned by private fleets. There is some question about the sustainability of M85 growth rates throughout the country, since growth has come almost exclusively from Federal, State, and local government expansion or incentives for the private sector in California.

\section{Methanol Neat (M100) Vehicles}

There was little growth in M100-fueled vehicles from 1992 to 1993, and no growth is expected to take place in 1995. In fact, this AFV group is expected to lose one heavy-duty vehicle in 1995 . Essentially all M100-fueled vehicles are heavy duty and, with one exception in 1995, owned by State and local governments. Due to issues raised by the test and demonstration program for methanol buses, the transit authorities in California are looking at other fuel options (e.g., natural gas).

\section{Ethanol (E85) Vehicles}

From 1993 to 1995, the number of privately owned E85-fueled vehicles is expected to remain almost unchanged. The E85 group's expansion continues at a rapid pace largely due to Midwestern State government programs. About 55 percent of all E85fueled vehicles in 1995 will be in State and local government fleets. Aside from the corn growers associations and ethanol producers themselves, the private sector is not expected to use E85-fueled vehicles.

\section{Ethanol (E95) Vehicles}

From 1993 to 1995, the stock of E95-fueled vehicles is expected to increase from 27 to 33 . E95-fueled vehicle increases are solely the result of government acquisitions in the Midwestern region. The private market for E95-fueled vehicles is almost nonexistent. The market for dedicated ethanol-fueled vehicles suffers from the same limitations as those of E85fueled vehicles. 
Table 7. Projected Privately Owned and State and Local Government Alternative Fueled Vehicles in Use by Census Region, 1995.

\begin{tabular}{|c|c|c|c|c|c|}
\hline \multirow[b]{2}{*}{ Fuel } & \multicolumn{4}{|c|}{ Percent of U.S. Total } & \multirow[b]{2}{*}{ U.S.Total } \\
\hline & Northeast & South & Midwest & West & \\
\hline $\mathrm{LPG}^{1} \ldots \ldots \ldots \ldots$ & 11 & 34 & 26 & 29 & $>299,000$ \\
\hline CNG & 15 & 35 & 17 & 33 & 84,701 \\
\hline LNG & 0 & 91 & 4 & 5 & 439 \\
\hline$\ldots \ldots \ldots \ldots$ & 1 & 1 & 1 & 98 & 10,476 \\
\hline M100 $\ldots \ldots \ldots$ & 5 & 2 & 0 & 93 & 413 \\
\hline E85 & * & 1 & 95 & 4 & 507 \\
\hline$\ldots \ldots \ldots$ & 0 & 6 & 94 & 0 & 33 \\
\hline Electricity $\ldots \ldots \ldots$ & 16 & 13 & 4 & 68 & 2,197 \\
\hline All Fuels $\ldots \ldots \ldots$ & 11 & 33 & 24 & 32 & $>397,766$ \\
\hline
\end{tabular}

'U.S. total represents lower bound estimates.

- Less than 0.5 percent rounded to 0 .

Notes: $\cdot$ Components may not add to 100 percent due to rounding. $\cdot$ Fuel terms are defined in the Glossary. LPG = Liquefied Petroleum Gases; CNG = Compressed Natural Gas; LNG = Liquefied Natural Gas; M85 = mixture of 85\% Methanol, 15\% Gasoline; M100 = Neat Methanol; E85 $=$ mixture of $85 \%$ Ethanol, $15 \%$ Gasoline; $E 95=$ mixture of $95 \%$ Ethanol, $5 \%$ Gasoline.

Source: Science Applications International Corporation, "Alternative Transportation Fuels and Vehicles Data Development," unpublished final report prepared for the Energy Information Administration, (McLean, VA, August 1994).

\section{Electric Vehicles}

From 1992 to 1995 , the number of electric vehicles is expected to increase in all weight classes for both private and State and local governments. Growth is primarily driven by State government mandates and regulations (e.g., California and New England's zero-emission vehicle mandates), private owner purchases, and conversions in California, Arizona, and Colorado.

Overall, the electric vehicle inventory is expected to grow slightly more than 21 percent from 1993 to 1995. This growth rate reflects demonstration program results and definitional problems. Encouraging advancements in battery technology (e.g., increased storage capacity, lighter weights, faster recharging, lower costs) may address concerns raised by many fleet operators (e.g., Public Service Co. of New Mexico, several public utilities in
Pennsylvania, etc.) as a result of field tests and demonstrations. These concerns include limited range, power, cost and reliability. In terms of definitional problems, it is important to note that unlike LPG-, alcohol-, and natural gas-fueled vehicles, many electric vehicles are operated as part of demonstration programs or are driven sparingly. ${ }^{5}$ In addition, questions regarding State and Federal reporting requirements and ease of conversion make enumeration and estimation of electric vehicles subject to large uncertainties. ${ }^{6}$

A relatively small group of hobbyists have taken interest in electric vehicles. Some of these enthusiasts are members of electric vehicle associations and routinely perform vehicle conversions themselves. However, the number of new hobbyists interested in electric vehicles is not expected to considerably affect the overall electric vehicle growth rate. 


\section{Notes}

${ }^{1}$ As of October 7, 1994, the following metropolitan areas had been inducted into the Clean Cities Program: Atlanta, GA; Denver, CO; Philadelphia, PA; Wilmington, DE; Las Vegas, NV; Washington, DC; Boston, MA; Austin, TX; Florida Gold Coast; Chicago, IL; Albuquerque, NM; Wisconsin Southeast area; Colorado Springs, CO; Long Beach, CA; Lancaster, PA; Salt Lake City, UT; White Plains, NY; and Baltimore, MD.

2The AFV configuration definitions given in this report were chosen by the EIA. Because no standardized definitions exist, the EIA configuration definitions may differ from those cited elsewhere.

${ }^{3}$ Transportation Energy Data Book, Edition 14, Table 3.3, pp 3-8, (May 1994, Oak Ridge National Laboratory, under U.S. Department of Energy Contract No. DE-AC05-840R 21400).

${ }^{4}$ Regional data for Federal vehicles, which represented about 3 percent of total AFV's in 1993, could not be obtained using the current methodology.

${ }^{5}$ An electric vehicle may travel five to eight miles per kilowatthour of charge; a typical battery system will hold 10 kilowatthours of electricity.

'For instance, a large number of electric vehicles are conversions made by hobbyists and may not run like a normal on-road vehicle. In that sense, some electric vehicles are not replacing conventional ones. In addition, although all electric vehicles are battery-powered, some may be hybrid (e.g., have a small generator using traditional fuels), have photovoltaic devices to capture solar energy, or partially rely on fuelcells. There are two main problems with enumeration sources: first, many electric vehicles are converted by hobbyist-owners and may remain undetected by ATF experts; second, electric vehicle associations used as sources may tend to exaggerate vehicle populations. 

$-$ 


\section{Alternative and Replacement Fuel Consumption}

\section{Background}

This chapter presents estimates of alternative fuel consumption for 1992, 1993 and 1995 as well as the consumption of oxygenates, which are the primary replacement fuels blended into gasoline. ${ }^{1}$ Fuel consumption estimates are given in gasolineequivalent gallons to allow comparisons of different fuel types. However, gasoline-equivalent gallons do not represent gasoline displacement. Since 1992, the consumption of alternative fuels and oxygenates by U.S. on-road vehicles has increased. From 1992 to 1995, the alternative fuel and oxygenate market share of on-road transportation fuel consumption increased from 1.6 percent to 3.3 percent. Federal legislation, Federal and State incentive programs, and cooperative efforts by fuel suppliers are principally responsible for the increase in the market penetration of alternative and replacement fuels. On a gasoline-equivalent gallon basis, alternative and replacement fuels represented 2.3 percent of the entire transportation fuel market in 1993.

\section{Estimated Vehicle Fuel Consumption in 1992, 1993, and 1995}

Alternative fuels accounted for 0.22 percent of onroad transportation fuel use in 1993, up from 0.17 percent in 1992 (Table 8). In 1993, oxygenates contributed about 2.5 percent of the 1993 gasoline volume consumed, up from 1.7 percent in 1992. From 1992 to 1993 the consumption of all alternative and replacement fuels, with the exception of E95 and electricity, increased faster than traditional fuels. The two leading alternative fuels in both 1992 and 1993 were LPG and CNG, which together accounted for almost 98 percent of all alternative fuel consumption in 1993. The leading oxygenate in 1992 and 1993 was methyl tertiary butyl ether (MTBE), representing almost 1.9 percent of gasoline consumption in 1993. Ethanol contributed almost 0.7 percent.

By 1995, the share of on-road transportation fuel consumption attributable to alternative and replacement fuels is expected to reach 3.3 percent. The leading alternative fuel in 1995 will continue to be LPG. Natural gas use is expected to more than triple from 1993 to 1995, making this fuel the fastest growing alternative fuel. Consumption of E85 is expected to almost double during the same period. However, given the size of the 1993 base, this represents only an increase of 41,000 gasolineequivalent gallons. Use of MTBE is expected to reach roughly 3.1 billion gasoline-equivalent gallons in 1995, followed by ethanol in gasohol, which is estimated to reach over 871 million gasolineequivalent gallons.

\section{Estimation Methods}

The alternative fuel consumption estimates were based on four inputs: (1) alternative fueled vehicle (AFV) inventories, (2) conventional vehicle-milestraveled (VMT), (3) miles-per-gallon (MPG) on conventional fuel, and (4) thousands of Btu per native unit of fuel. In addition, several assumptions are required, including annual miles traveled by AFV's and fuel efficiency by vehicle type, measured in miles per gasoline-equivalent gallon (MPG). Gasoline-equivalent gallons is computed by dividing the lower heating value of the alternative fuel by the lower heating value of gasoline and multiplying this result by the alternative fuel consumption value.

Assumptions were also developed to account for differences in fuel type, ownership (private versus government), classification (auto, light-duty truck, heavy-duty truck, school/transit bus), and fleet type (e.g., rental and service, passenger, and government light-duty vehicle pools). Finally, the estimates were adjusted according to the contribution of VMT from alternative and replacement fuels consumed in dedicated versus dual-, bi-, and flexible-fueled vehicles. Appendix B provides details on the fuel consumption estimation methods.

\section{Alternative Fuel Consumption by Fuel Type, Vehicle Ownership, and Weight Class, 1992}

Liquefied petroleum gases, $\mathrm{CNG}$, and methanol were the only alternative fuels consumed in significant quantities during 1992 (Table 9). On-road use of LPG fuel in 1992 was estimated to be at least 208 million gasoline-equivalent gallons (283 million gallons of LPG). Vehicle transportation use of CNG accounted for about 17 million gasoline-equivalent gallons. There was minimal on-road vehicle consumption of LNG. Methanol (M85 and M100) accounted for 1.6 percent of on-road alternative 
Table 8. Consumption of Vehicle Fuels, 1992, 1993, and 1995 (Thousand gasoline-equivalent gallons)

\begin{tabular}{|c|c|c|c|}
\hline \multirow[b]{2}{*}{ Fuel } & \multicolumn{3}{|c|}{ Consumption } \\
\hline & 1992 & 1993 & 1995 \\
\hline \multicolumn{4}{|l|}{ Alternative and Replacement Fuels } \\
\hline \multicolumn{4}{|l|}{ Alternative Fuels } \\
\hline $\mathrm{LPG}^{1} \ldots \ldots \ldots \ldots \ldots \ldots$ & 208,142 & 264,655 & 293,773 \\
\hline CNG $\ldots \ldots \ldots \ldots \ldots$ & 16,823 & 21,603 & 66,783 \\
\hline LNG $\ldots \ldots \ldots \ldots \ldots \ldots$ & 585 & 1,900 & 2,734 \\
\hline$M 85^{2} \ldots \ldots \ldots \ldots \ldots \ldots$ & 1,069 & 1,593 & 3,411 \\
\hline 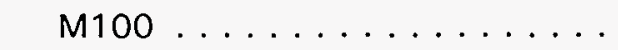 & 2,547 & 3,166 & 3,160 \\
\hline$E 85^{2} \ldots \ldots \ldots \ldots \ldots$ & 21 & 48 & 89 \\
\hline${\mathrm{E} 95^{2}}^{2} \ldots \ldots \ldots \ldots \ldots$ & 85 & 80 & 104 \\
\hline Electricity $\ldots \ldots \ldots \ldots$ & 374 & 309 & 525 \\
\hline Subtotal $\ldots \ldots \ldots \ldots$ & 229,646 & 293,355 & 370,580 \\
\hline \multicolumn{4}{|l|}{ Oxygenates } \\
\hline MTBE . . & $1,175,000$ & $2,069,200$ & $3,128,600$ \\
\hline Ethanol in gasohol & 701,000 & 760,000 & 871,030 \\
\hline Other alcohols and ethers ${ }^{3} \ldots$ & NA & NA & 201,200 \\
\hline Total $\ldots \ldots \ldots \ldots \ldots \ldots$ & $2,105,646$ & $3,122,555$ & $4,571,410$ \\
\hline \multicolumn{4}{|l|}{ Traditional Fuels } \\
\hline Gasoline ${ }^{4} \ldots$ & $110,135,000$ & $111,323,000$ & $113,914,000$ \\
\hline$\ldots \ldots \ldots \ldots$ & $23,866,000$ & $24,296,630$ & $25,965,830$ \\
\hline Total Fuel Consumption 5 & $134,230,646$ & $135,912,985$ & $140,250,410$ \\
\hline
\end{tabular}

${ }^{1}$ Values represent lower bound estimates.

${ }^{2}$ Consumption includes gasoline portion of the mixture.

${ }^{3}$ Primarily includes Tertiary Amyl Methyl Ether (TAME) and Ethyl Tertiary Butyl Ether (ETBE).

${ }^{4}$ Gasoline consumption includes ethanol in gasohol and MTBE.

${ }^{5}$ Total fuel consumption represents the sum of the Alternative Fuels Subtotal, Gasoline, and Diesel consumption. Gasoline consumption already includes oxygenates.

NA = not available.

Notes: - Totals may not equal sum of components due to independent rounding. $\cdot$ Fuel quantities are expressed in a common base unit of gasolineequivalent gallons to allow comparisons of different fuel types. Gasoline-equivalent gallons do not represent gasoline displacement. Gasoline equivalent is computed by dividing the lower heating value of the alternative fuel by the lower heating value of gasoline and multiplying this result by the alternative fuel consumption value. Lower heating value is defined in the Glossary. $\cdot$ Fuel terms are defined in the Glossary. LPG = Liquefied Petroleum Gases; CNG = Compressed Natural Gas; LNG = Liquefied Natural Gas; M85 = mixture of $85 \%$ Methanol, $15 \%$ Gasoline; M100 = Neat Methanol; E85 = mixture of $85 \%$ Ethanol, $15 \%$ Gasoline; E95 = mixture of $95 \%$ Ethanol, $5 \%$ Gasoline; MTBE = Methyl Tertiary Butyl Ether.

Sources: 1992 Oxygenate Consumption: Energy Information Administration, Petroleum Supply Monthly, (January 1993). 1992 TraditionalFuel Consumption: Energy Information Administration, Petroleum Supply Annual, Volume 1, (June 1994). Highway use of gasoline was estimated as 97.1 percent of consumption, based on data in the Transportation Energy Data Book: Edition 14, prepared by Oak Ridge National Laboratory for the U.S. Department of Energy (March 1993). Diesel consumption adjusted for highway use by multiplying by .567, derived for Energy Information Administration, Fuel Oil and Kerosene Sales 1992, Table HL1. 1993 Oxygenate Consumption: Energy Information Administration, Petroleum Supply Monthly, (June 1994). 1993 Traditional Fuel Consumption: Energy Information Administration, Petroleum Supply Annual, Volume 1. Gasoline consumption adjusted for highway use as in 1992. Diesel consumption adjusted for highway use as in 1992.1992 and 1993 Estimated and 1995 Projected Altemative Fuel Consumption: Science Applications International Corporation, "Alternative Transportation Fuels and Vehicles Data Development," unpublished final report prepared for the Energy Information Administration, (McLean, VA, August 1994). 1995 Projected Oxygenate and Traditional Fuel Consumption: EIA, Short Term Energy Outlook, 3rd Quarter 1994. 


\begin{tabular}{|c|c|c|}
\hline Fuel & $\begin{array}{c}\text { Consumption in } \\
\text { Native Units } \\
\text { (Thousand gallons except where } \\
\text { otherwise noted) }\end{array}$ & $\begin{array}{l}\text { Consumption in } \\
\text { Gasoline Equivalent Units } \\
\text { (Thousand gallons) }\end{array}$ \\
\hline \multicolumn{3}{|l|}{ Alternative and Replacement Fuels } \\
\hline \multicolumn{3}{|l|}{ Alternative Fuels } \\
\hline $\mathrm{LPG}^{2} \ldots \ldots \ldots \ldots \ldots \ldots$ & 283,270 & 208,142 \\
\hline CNG (thousand cubic feet) . . . . . . & $2,083,210$ & 16,823 \\
\hline LNG $\ldots \ldots \ldots \ldots \ldots \ldots$ & 880 & 585 \\
\hline $\mathrm{M} 85^{3} \ldots \ldots \ldots \ldots \ldots$ & 1,875 & 1,069 \\
\hline$M 100 \ldots \ldots \ldots \ldots$ & 5,160 & 2,547 \\
\hline$E 85^{3} \ldots \ldots \ldots \ldots \ldots$ & 38 & 21 \\
\hline$E 95^{3} \ldots \ldots \ldots \ldots \ldots$ & 163 & 85 \\
\hline Electricity (thousand $\mathrm{kWh}$ ) . . . . . . . & 12,580 & 374 \\
\hline 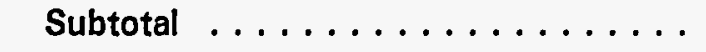 & -- & 229,646 \\
\hline \multicolumn{3}{|l|}{ Oxygenates } \\
\hline MTBE $\ldots \ldots \ldots \ldots \ldots \ldots$ & $1,460,000$ & $1,175,000$ \\
\hline Ethanol in gasohol $\ldots \ldots \ldots$. . . . & $1,036,000$ & 701,000 \\
\hline Other alcohols and ethers ${ }^{4} \ldots \ldots \ldots$ & NA & NA \\
\hline Total $\ldots \ldots \ldots \ldots \ldots \ldots$ & -- & $2,105,646$ \\
\hline \multicolumn{3}{|l|}{ Traditional Fuels } \\
\hline Gasoline $^{5} \ldots \ldots \ldots \ldots \ldots$ & $110,135,000$ & $110,135,000$ \\
\hline Diesel $\ldots \ldots \ldots \ldots \ldots \ldots$ & $21,375,000$ & $23,866,000$ \\
\hline Total Vehicle Fuel Consumption $^{6} \ldots$. . & $-\cdot$ & $134,230,646$ \\
\hline 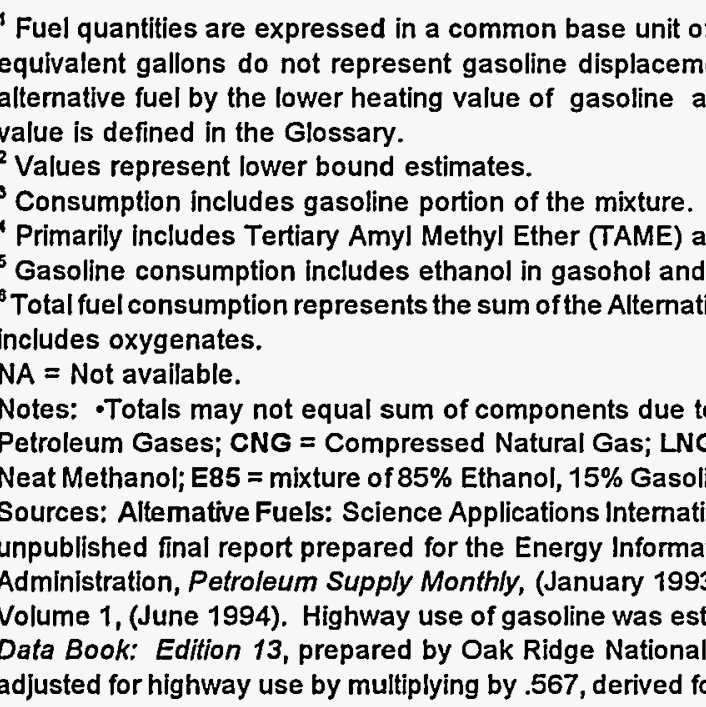 & $\begin{array}{l}\text { Gasoline-equivalent gallons to allow } \\
\text { multiplying this result by the altern } \\
\text { Ethyl Tertiary Butyl Ether (ETBE). } \\
\text { TBE. } \\
\text { Fuels Subtotal, Gasoline, and Diese } \\
\text { Idependent rounding. - Fuel terms } \\
\text { Liquefied Natural Gas; M85 = mixt } \\
\text {;E95 = mixture of } 95 \% \text { Ethanol, } 5 \% \\
\text { al Corporation, "Alternative Transpo } \\
\text { Administration, (McLean, VA, Aug } \\
\text { Traditional Fuels: Energy Informat } \\
\text { ated as } 97.1 \text { percent of consumptiol } \\
\text { Eoratory for the U.S. Department } 0 \\
\text { Energy Information Administration, } F\end{array}$ & $\begin{array}{l}\text { risons of different fuel types. Gasoline- } \\
\text { dividing the lower heating value of the } \\
\text { uel consumption value. Lower heating } \\
\text { Amption. Gasoline consumption already } \\
\text { fined in the Glossary. LPG = Liquefied } \\
\text { n5\% Methanol, 15\% Gasoline; M100 = } \\
\text { Fuels and Vehicles Data Development," } \\
\text { 94). Oxygenates: Energy Information } \\
\text { ministration, Petroleum Supply Annual, } \\
\text { ed on data in the Transportation Energy } \\
\text { gy (March 1993). Diesel consumption } \\
\text { and Kerosene Sales 1992, Table HL1. }\end{array}$ \\
\hline
\end{tabular}

fuel consumption in 1992. Of the approximately 4 million gasoline-equivalent gallons of methanol fuels consumed, 70 percent was M100, and 30 percent was M85. In comparison to methanol, there was very little consumption of E85 and E95 in 1992. Over 12 million kilowatthours of electricity (about 370,000 equivalent-gallons of gasoline) were consumed by electric vehicles. 


\section{Fuel Consumption by Weight Class}

Light-duty vehicles accounted for nearly two-thirds (152 million gasoline-equivalent gallons) of the total alternative fuels consumed in 1992 (Table 10). The majority of LPG, CNG, M85, E85, and electricity consumption for AFV's was in the light-duty vehicle weight class. The estimated total alternative transportation fuel (ATF) consumption by heavy-duty vehicles in 1992 was about 77 million gasolineequivalent gallons. Although heavy-duty vehicles made up only 19 percent of total AFV's in 1992, they consumed 34 percent of total ATF's. This high amount of fuel consumption was primarily due to the higher average VMT and lower fuel efficiencies of heavy-duty vehicles. Heavy-duty vehicles, for example, accounted for only 3 percent of the M85 vehicles in use, but accounted for 43 percent of M85 fuel consumed. Many of the heavy-duty M85 vehicles are urban transit buses. Similarly, heavyduty electric vehicles represented less than 1 percent of the electric vehicle population, but consumed 40 percent of the electricity used as vehicle fuel.

\section{Federal Alternative Fuel Consumption}

Compressed natural gas and M85 together accounted for 98 percent of the alternative fuels consumed by vehicles in the Federal sector in 1992, with 211,000 and 302,000 gasoline-equivalent gallons, respectively (Table 11). Liquefied petroleum gases represented less than 2 percent of total Federal ATF consumed in 1992. Federal government AFV's also consumed small amounts of electricity and E85. Liquefied natural gas, M100, and E95 were not consumed by any vehicles in the Federal sector.

\section{State and Local Government Alternative Fuel Consumption}

Liquefied petroleum gases accounted for over 6 million gasoline-equivalent gallons consumed by vehicles in the State and local government sector in 1992, while 5 million gasoline-equivalent gallons of CNG were consumed. Neat methanol and M85 combined accounted for 21 percent of the alternative fuel consumed by State and local government

Table 10. Consumption of Alternative Fuels by Vehicle Weight Classification, 1992 (Thousand gasoline-equivalent gallons)

\begin{tabular}{|c|c|c|c|}
\hline Fuel & Light Duty ${ }^{\top}$ & Heavy Duty ${ }^{1}$ & Total \\
\hline $\mathrm{LPG}^{2} \ldots \ldots \ldots \ldots \ldots$ & 141,042 & 67,100 & 208,142 \\
\hline CNG $\ldots \ldots \ldots \ldots \ldots$ & 10,477 & 6,345 & 16,823 \\
\hline LNG $\ldots \ldots \ldots \ldots \ldots$ & * & 583 & 585 \\
\hline$M 85^{3} \ldots$ & 607 & 461 & 1,069 \\
\hline$M 100 \ldots \ldots \ldots \ldots$ & 13 & 2,534 & 2,547 \\
\hline$E 85^{3} \ldots \ldots \ldots$ & 20 & 1 & 21 \\
\hline E95 $^{3} \ldots \ldots \ldots \ldots$ & 3 & 82 & 85 \\
\hline Electricity $\ldots \ldots \ldots \ldots$ & 226 & 148 & 374 \\
\hline Total & 152,388 & 77,254 & 229,646 \\
\hline
\end{tabular}

'Weight classes based on Environmental Protection Agency definitions: Light Duty $\leq 8,500$ pounds Gross Vehicle Weight (GVW); Heavy Duty $>8,500$ pounds GWW.

${ }^{2}$ Values represent lower bound estimates.

${ }^{3}$ Consumption includes gasoline portion of the mixture.

- Less than 0.5 thousand gasoline-equivalent gallons.

Notes: - Totals may not equal sum of components due to independent rounding. - Fuel quantities are expressed in a common base unit of gasoline-equivalent gallons to allow comparisons of different fuel types. Gasoline-equivalent gallons do not represent gasoline displacement. Gasoline equivalent is computed by dividing the lower heating value of the alternative fuel by the lower heating value of gasoline and multiplying this result by the alternative fuel consumption value. Lower heating value is defined in the Glossary. P Fuel terms are defined in the Glossary. LPG = Liquefied Petroleum Gases; CNG = Compressed Natural Gas; LNG = Liquefied Natural Gas; M85 = mixture of $85 \%$ Methanol, $15 \%$ Gasoline; M100 $=$ Neat Methanol; E85 = mixture of $85 \%$ Ethanol, $15 \%$ Gasoline; E95 $=$ mixture of $95 \%$ Ethanol, $5 \%$ Gasoline. Source: Science Applications International Corporation, spreadsheet prepared for the Energy Information Administration, (McLean, VA, August 1994). 
vehicles. State and local governments consumed the majority (90 percent) of fuel ethanol (E85 and E95).

\section{Privately Owned Alternative Fueled Vehicle Consumption}

The private sector was the largest user of LPG, CNG, and electricity in 1992. Private sector LPG consumption was 97 percent of the total. Privately owned vehicles accounted for nearly 60 percent (218,000 gasoline-equivalent gallons) of electricity used as a transportation fuel in 1992. Over 11 million gasoline-equivalent gallons of CNG were consumed by privately owned vehicles in 1992, around 70 percent of total $\mathrm{CNG}$ use. Privately owned AFV's accounted for less than 1 percent of total methanol (M85 and M100) consumption.

\section{Oxygenate Consumption in 1992}

Oxygenates have been used in gasoline for a number of years. Ethanol has been used at various times and places to increase the volume of gasoline available. Methyl tertiary butyl ether came into use in the late 1970s as a means of increasing gasoline octane levels. The Clean Air Act Amendments of 1990 (CAAA) have provided the strongest incentive to increase use of these additives. The CAAA requires that, beginning in November 1992, gasoline sold in carbon monoxide (CO) nonattainment areas during the high $\mathrm{CO}$ season must contain at least 2.7 percent oxygen by weight. Increasing oxygen content is achieved by blending oxygenates into the gasoline. The CAAA also mandates the use of "reformulated" gasoline year-round in specified ozone nonattainment areas starting in 1995. Reformulated gasoline also must include specified levels of oxygen. More recently, the EPACT established goals for petroleum fuel displacement that are also expected to add some impetus to oxygenate use.

In 1992, 1,036 million gallons of ethanol were consumed as a gasoline blending component (Table 9). Also, about 1.5 billion gallons of MTBE were blended into gasoline. The consumption of oxygenates in 1992 reflects the beginning of the new oxygenated gasoline requirements. Over 30 percent of U.S. gasoline sales in November and December

Table 11. Consumption of Alternative Fuels by Vehicle Ownership, 1992 (Thousand gasoline-equivalent gallons)

\begin{tabular}{|c|c|c|c|c|}
\hline Fuel & $\begin{array}{c}\text { Federal } \\
\text { Government }\end{array}$ & $\begin{array}{l}\text { State and Local } \\
\text { Government }\end{array}$ & Private & Total \\
\hline $\mathrm{LPG}^{1} \ldots \ldots$ & 8 & 6,189 & 201,944 & 208,142 \\
\hline CNG $\ldots \ldots \ldots$ & 211 & 5,298 & 11,314 & 16,823 \\
\hline LNG $\ldots \ldots \ldots$ & 0 & 490 & 93 & 585 \\
\hline$M 85^{2} \ldots \ldots$ & 302 & 757 & 9 & 1,069 \\
\hline$M 100 \ldots \ldots$ & 0 & 2,534 & 12 & 2,547 \\
\hline${\mathrm{E} 85^{2}}^{2} \ldots \ldots$ & 1 & 13 & 7 & 21 \\
\hline $\mathrm{Eg5}^{2} \ldots \ldots \ldots$ & 0 & 80 & 5 & 85 \\
\hline Electricity $\ldots \ldots$ & 4 & 152 & 218 & 374 \\
\hline Total . . . . . . . & 526 & 15,513 & 213,602 & 229,646 \\
\hline
\end{tabular}

\footnotetext{
${ }^{1}$ Values represent lower bound estimates.

${ }^{2}$ Consumption includes gasoline portion of the mixture.

Notes: -Totals may not equal sum of components due to independent rounding. - Fuel quantities are expressed in a common base unit of gasoline-equivalent gallons to allow comparisons of different fuel types. Gasoline-equivalent gallons do not represent gasoline displacement. Gasoline equivalent is computed by dividing the lower heating value of the alternative fuel by the lower heating value of gasoline and multiplying this result by the alternative fuel consumption value. Lower heating value is defined in the Glossary. P Fuel terms are defined in the Glossary. LPG = Liquefied Petroleum Gases; CNG = Compressed Natural Gas; LNG = Liquefied Natural Gas; M85 = mixture of $85 \%$ Methanol, $15 \%$ Gasoline; $M 100=$ Neat Methanol; E85 = mixture of $85 \%$ Ethanol, $15 \%$ Gasoline; E95 = mixture of $95 \%$ Ethanol, $5 \%$ Gasoline. Source: Science Applications International Corporation, spreadsheet prepared for the Energy Information Administration, (McLean, VA, August 1994).
} 
1992 were oxygenated gasoline. ${ }^{2}$ Methyl tertiary butyl ether and ethanol were virtually the only oxygenates used. During the first oxygenated gasoline season (November 1992 through January 1993 for most areas), MTBE supplied about 58 percent of the oxygen while ethanol supplied about 42 percent. $^{3}$ (Each gallon of ethanol contains about 30 percent more oxygen than each gallon of MTBE.)

\section{Alternative Fuel Consumption Estimates by Fuel Type, and by Vehicle Ownership and Weight Class, 1993 and 1995}

In 1993, alternative fuels accounted for 0.22 percent of total on-road fuel use. The proportion is expected to increase to 0.26 percent by 1995 (Table 12). Liquefied petroleum gases alone accounted for at least 90 percent of alternative fuel consumption on a gasoline-equivalent basis in 1993. Consumption of LPG is expected to increase 11 percent from 1993 to 1995 , but LPG will represent only 79 percent of alternative fuel consumption in 1995 due to the relatively higher growth rates for the other fuels.

Approximately 21 million gasoline-equivalent gallons of CNG were consumed in 1993, with the level of consumption expected to more than triple by 1995 . Consumption of LNG, M85, M100, E85, E95, and electricity combined accounted for only 2.4 percent of total alternative fuel consumption in 1993. Consumption of these fuels is projected to increase to a 2.7-percent share by 1995 . The consumption of M85 is estimated to more than double from 1993 to 1995 . Vehicle consumption of electricity is expected to grow 70 percent from 1993 to 1995. On the other hand, consumption of alcohol fuels, except M85, is expected to grow at a slower pace. Neat methanol consumption is projected to remain unchanged during this time period, while consumption of E85 and E95 will increase slightly by 1995 .

Other factors besides changes in the number of vehicles account for year-to-year changes in ATF consumption. For example, the mix of vehicles by weight classification and fuel type, and the proportion of alternative fuels used in bi-fueled, dual-fueled, or flexible-fueled vehicles, can cause growth rates of vehicles and fuel consumption to differ. The mix of light-duty and heavy-duty vehicles is the most important factor. Heavy-duty vehicles, especially transit and intercity buses, consume much more fuel per vehicle than light-duty vehicles. Heavy-duty vehicles accounted for a greater proportion of vehicle growth from 1992 to 1993, and alternative fuel consumption increased faster (approximately 28 percent) than the total number of vehicles (25 percent). From 1993 to 1995 , light-duty vehicles are expected to grow faster than heavy-duty vehicles, while fuel consumption increases at a slower rate.

\section{Fuel Consumption by Weight Class}

An estimated 178 million gasoline-equivalent gallons of LPG will be consumed by light-duty vehicles in 1995, up from 161 million gasoline-equivalent gallons in 1993 (Table 13). In both years, 39 percent of LPG is consumed by heavy-duty vehicles. Use of CNG is expected to more than double from 1993 to 1995 for light-duty vehicles and to quadruple for heavy-duty vehicles. For the same period, LNG also increases.

For the period 1993 through 1995, M85 fuel consumption will also more than double for lightduty vehicles, reflecting the rapid growth in the private and State automobile fleets in California. Neat methanol consumption will remain relatively unchanged over the period because of the lack of growth in California's transit bus program.

Consumption of E85 and E95 is expected to increase in 1995 as a result of the growth in the number of E85 automobiles and E95 buses in the Midwest. However, most ethanol fuel is consumed as a constituent of gasohol. Electricity consumed by light-duty vehicles is estimated to increase 17 percent from 1993 to 1995, reflecting modest gains in light-duty vehicle numbers. Consumption of electricity by heavy-duty vehicles is estimated to more than triple due to recent purchases of electric shuttle buses in Georgia, Hawaii, Indiana, Minnesota, New York, Tennessee, and Virginia.

\section{Federal Fuel Consumption}

Federal ATF consumption is expected to more than double between 1993 and 1995 (Table 14). Compressed natural gas and M85 combined accounted for 98 percent of the fuel consumed by Federal sector AFV's in 1993, and is expected to be slightly lower in 1995. Liquefied petroleum gases and E85 represented the third- and fourth-largest ATF's consumed, with roughly 2 percent of total Federal ATF consumption in 1993. In 1995, LPG and E85 are projected to account for almost 5 percent of Federal ATF consumption. 


\begin{tabular}{|c|c|c|c|c|}
\hline \multirow[b]{2}{*}{ Fuel } & \multicolumn{2}{|c|}{1993} & \multicolumn{2}{|l|}{1995} \\
\hline & $\begin{array}{c}\text { Consumption in } \\
\text { Native Units } \\
\text { (Thousand gallons except } \\
\text { where otherwise noted) }\end{array}$ & $\begin{array}{l}\text { Consumption in } \\
\text { Gasoline } \\
\text { Equivalent Units } \\
\text { (Thousand gallons) } \\
\end{array}$ & $\begin{array}{l}\text { Consumption in } \\
\text { Native Units } \\
\text { (Thousand gallons except } \\
\text { where otherwise noted) }\end{array}$ & $\begin{array}{l}\text { Consumption in } \\
\text { Gasoline } \\
\text { Equivalent Units' } \\
\text { (Thousand gallons) }\end{array}$ \\
\hline \multicolumn{5}{|l|}{$\begin{array}{l}\text { Alternative and Replacement Fuels } \\
\text { Alternative Fuels }\end{array}$} \\
\hline$\ldots \ldots \ldots \ldots$ & 360,181 & 264,655 & 399,804 & 293,773 \\
\hline CNG (thousand cubic feet) . . . & $2,674,243$ & 21,603 & $8,262,857$ & 66,783 \\
\hline$\ldots \ldots \ldots \ldots$ & 2,864 & 1,900 & 4,121 & 2,734 \\
\hline$\ldots \ldots \ldots \ldots \ldots$ & 2,796 & 1,593 & 5,943 & 3,411 \\
\hline 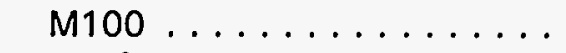 & 6,410 & 3,166 & 6,398 & 3,160 \\
\hline$E 85^{3} \ldots \ldots \ldots \ldots \ldots$ & 85 & 48 & 156 & 89 \\
\hline${\mathrm{E} 95^{3}}^{3} \ldots \ldots \ldots \ldots$ & 153 & 80 & 200 & 104 \\
\hline Electricity (thousand $\mathrm{kWh}$ ) . . . & 10,425 & 309 & 17,108 & 525 \\
\hline Subtotal $\ldots \ldots \ldots \ldots$ & - & 293,355 & - & 370,580 \\
\hline \multicolumn{5}{|l|}{ Oxygenates } \\
\hline MTBE $\ldots \ldots \ldots \ldots \ldots \ldots$ & $2,545,000$ & $2,069,200$ & $3,848,000$ & $3,128,600$ \\
\hline Ethanol in gasohol $\ldots \ldots \ldots$ & $1,150,000$ & 760,000 & $1,318,000$ & 871,030 \\
\hline Other alcohols and ethers ${ }^{4} \ldots$ & NA & NA & 230,000 & 201,200 \\
\hline Total $\ldots \ldots \ldots \ldots \ldots$ & - & $3,122,555$ & $\cdots$ & $4,571,410$ \\
\hline \multicolumn{5}{|l|}{ Traditional Fuels } \\
\hline Gasoline $^{5}$. & $111,323,000$ & $111,323,000$ & $113,914,000$ & $113,914,000$ \\
\hline Diesel $\ldots \ldots \ldots \ldots \ldots$ & $21,761,000$ & $24,296,630$ & $23,256,000$ & $25,965,830$ \\
\hline Total Fuel Consumption ${ }^{6} \ldots$ & - & $135,912,985$ & - & $140,250,410$ \\
\hline
\end{tabular}

' Fuel quantities are expressed in a common base unit of gasoline-equivalent gallons to allow comparisons of different fuel types. Gasolineequivalent gallons do not represent gasoline displacement. Gasoline-equivalent gallons is computed by dividing the lower heating value of the alternative fuel by the lower heating value of gasoline and multiplying this result by the alternative fuel consumption value. Lower heating value is defined in the Glossary.

${ }^{2}$ Values represent lower bound estimates.

3 Consumption includes gasoline portion of the mixture.

4 Primarily includes Tertiary Amyl Methyl Ether (TAME) and Ethyl Tertiary Butyl Ether (ETBE).

5 Gasoline consumption includes ethanol in gasohol and MTBE.

- Total fuel consumption represents the sum of the Alternative Fuels Subtotal, Gasoline, and Diesel consumption. Gasoline consumption already includes oxygenates.

NA $=$ not available.

Notes: Totals may not equal sum of components due to independent rounding. Fuel terms are defined in the Glossary. LPG $=$ Liquefied Petroleum Gases; CNG = Compressed Natural Gas; LNG = Liquefied Natural Gas; M85 = mixture of $85 \%$ Methanol, $15 \%$ Gasoline; M100 $=$ Neat Methanol; E85 = mixture of $85 \%$ Ethanol, $15 \%$ Gasoline; E95 = mixture of $95 \%$ Ethanol, $5 \%$ Gasoline; MTBE = Methyl Tertiary Butyl Ether.

Sources: 1993 Oxygenate Consumption: Energy Information Administration, Petroleum Supply Month/y, (June 1994). 1993 Gasoline and Diesel Consumption: Energy Information Administration, Petroleum Supply Annual, Volume 1. Gasoline consumption adjusted for highway use as in 1992. Diesel consumption adjusted for highway use by multiplying by 0.567 , derived from Energy Information Administration, Fuel Oil and Kerosene Sales, Table HL1. 1993 Estimated and 1995 Projected Alternative Fuel Consumption: Science Applications International Corporation, "Alternative Transportation Fuels and Vehicles Data Development," unpublished final report prepared for the Energy Information Administration, (McLean, VA, August 1994). 1995 Projected Oxygenate, Gasoline, and Diesel Consumption: ElA, Short Term Energy Outlook, 3rd Quarter 1994. 
Table 13. Consumption of Alternative Fuels by Vehicle Weight Classification, 1993 and 1995 (Thousand gasoline-equivalent gallons)

\begin{tabular}{|c|c|c|c|c|c|c|c|}
\hline \multirow{2}{*}{\multicolumn{2}{|c|}{ Fuel }} & \multicolumn{3}{|c|}{1993} & \multicolumn{3}{|c|}{1995} \\
\hline & & $\begin{array}{l}\text { Light } \\
\text { Duty }{ }^{1}\end{array}$ & $\begin{array}{l}\text { Heavy } \\
\text { Duty }\end{array}$ & Total & $\begin{array}{l}\text { Light } \\
\text { Duty }\end{array}$ & $\begin{array}{l}\text { Heavy } \\
\text { Duty }{ }^{1}\end{array}$ & Total \\
\hline $\mathrm{LPG}^{2}$. & $\ldots \ldots \ldots \ldots$ & 160,717 & 103,938 & 264,655 & 178,435 & 115,338 & 293,773 \\
\hline CNG & $\ldots \ldots \ldots \ldots$ & 14,388 & 7,214 & 21,603 & 38,632 & 28,150 & 66,782 \\
\hline LNG & 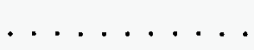 & 10 & 1,891 & 1,901 & 18 & 2,716 & 2,734 \\
\hline$M 85^{3}$ & & 1,545 & 48 & 1,593 & 3,337 & 74 & 3,411 \\
\hline M100 & 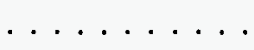 & 0 & 3,166 & 3,166 & 0 & 3,160 & 3,160 \\
\hline $\mathrm{E} 85^{3}$ & & 47 & 2 & 48 & 87 & 2 & 89 \\
\hline E95 ${ }^{3}$ & & 1 & 79 & 80 & 1 & 103 & 104 \\
\hline Electrici & ity $\ldots \ldots$ & 247 & 62 & 309 & 289 & 236 & 525 \\
\hline Total & $\ldots \ldots \ldots$ & 176,955 & 116,400 & 293,355 & 220,799 & 149,780 & 370,580 \\
\hline
\end{tabular}

${ }^{1}$ Weight classes based on Environmental Protection Agency definitions: Light Duty $\leq 8,500$ pounds Gross Vehicle Weight (GWW); Heavy Duty $>8,500$ pounds GWW.

${ }^{2}$ Values represent lower bound estimates.

${ }^{3}$ Consumption includes gasoline portion of the mixture.

Notes: -Quantities are expressed in a common base unit of gasoline-equivalent gallons only to allow comparison of different fuel types. Gasoline-equivalent gallons do not represent gasoline displacement. - Totals may not equal sum of components due to independent rounding. -Fuel terms are defined in the Glossary. LPG = Liquefied Petroleum Gases; CNG = Compressed Natural Gas; LNG = Liquefied Natural Gas; M85 = mixture of $85 \%$ Methanol, $15 \%$ Gasoline; M100 = Neat Methanol; E85 = mixture of $85 \%$ Ethanol, $15 \%$ Gasoline; E95 = mixture of $95 \%$ Ethanol, $5 \%$ Gasoline.

Source: 1993 Estimates and 1995 Projections: Science Applications International Corporation, "Alternative Transportation Fuels and Vehicles Data Development," unpublished final report prepared for the Energy Information Administration, (McLean, VA, August 1994) and spreadsheet prepared for the Energy Information Administration.

\section{State and Local Government Alternative Fuel Consumption}

Compressed natural gas is expected to represent 58 percent of State and local government alternative fuel consumption in 1995, compared to only 32 percent in 1993. While LNG use is expected to increase by nearly 50 percent (though a loss in market share), use of M100 will remain flat between 1993 and 1995. Almost all M100 consumption is by State and local governments, and is expected to be so in 1995. State and local government vehicles consumed most of the ethanol in 1993, and are expected to do the same in 1995 . Consumption of electricity as a transportation fuel by State and local governments is expected to more than triple from 1993 to 1995, rising almost to the usage level expected in the private sector.

\section{Privately Owned Alternative Fueled Vehicle Consumption}

In 1993, privately owned vehicles consumed the vast majority of alternative fuels, at least 270 million gasoline-equivalent gallons. Liquefied petroleum gases accounted for nearly 95 percent of this amount. By 1995, however, the private sector's share of alternative fuel consumption is expected to decrease due to greater growth expected in non-LPG consumption by Federal, State, and local governments. Compressed natural gas accounts for roughly 5 percent of fuel use in both 1993 and 1995. As a result, LPG and CNG account for virtually all private sector ATF consumption. Electric vehicles in the private sector consumed more fuel in 1993 than other sectors, and will continue to do so in 1995.

\section{Oxygenate Consumption in 1993 and 1995}

Consumption of oxygenates in 1993 reflected the impact of the first full year of oxygenated gasoline requirements. Consumption of oxygenates increased 51 percent from 1992 to 1993 in total gasolineequivalent volume (Table 12). Methyl tertiary butyl ether became the predominant oxygenate, with consumption increasing about 76 percent, while ethanol consumption increased 8 percent. Ethanol increases were constrained by little growth in production capacity, which was partly due to the uncertain status of ethanol tax exemptions and 
Table 14. Consumption of Alternative Fuels by Vehicle Ownership Class, 1993 and 1995

(Thousand gasoline-equivalent gallons)

\begin{tabular}{|c|c|c|c|c|c|c|}
\hline \multirow[b]{2}{*}{ Fuel } & \multicolumn{3}{|c|}{1993} & \multicolumn{3}{|c|}{1995} \\
\hline & Federal & State/Local & Private & Federal & State/Local & Private \\
\hline $\mathrm{LPG}^{1} \ldots \ldots \ldots$ & 14 & 9,433 & 255,207 & 143 & 10,473 & 283,157 \\
\hline CNG ........ & 842 & 6,930 & 13,831 & 2,415 & 23,597 & 40,769 \\
\hline LNG & 0 & 1,894 & 6 & 3 & 2,720 & 11 \\
\hline${\mathrm{M} 85^{2}}^{2}$ & 644 & 270 & 680 & 1,146 & 366 & 1,899 \\
\hline M100 ....... & 0 & 3,165 & * & 0 & 3,158 & 2 \\
\hline$E 85^{2} \ldots \ldots$ & 11 & 27 & 11 & 34 & 44 & 11 \\
\hline$\ldots \ldots$ & 0 & 74 & 6 & 0 & 98 & 6 \\
\hline Electricity .... & 4 & 75 & 231 & 21 & 244 & 259 \\
\hline Total . . . . . . . & 1,515 & 21,868 & 269,972 & 3,762 & 40,700 & 326,114 \\
\hline
\end{tabular}

'Values represent lower bound estimates.

${ }^{2}$ Consumption includes gasoline portion of the mixture.

- Less than one thousand gallons.

Notes: - Totals may not equal sum of components due to independent rounding. •Quantities are expressed in a common base unit of gasolineequivalent gallons only to allow comparison of different fuel types. Gasoline-equivalent gallons do not represent gasoline displacement. Gasoline equivalent is computed by dividing the lower heating value of the alternative fuel by the lower heating value of gasoline and multiplying this result by the alternative fuel consumption value. Lower heating value is defined in the Glossary. • Fuel terms are defined in the Glossary. LPG $=$ Liquefied Petroleum Gases; CNG = Compressed Natural Gas; LNG = Liquefied Natural Gas; M85 = mixture of $85 \%$ Methanol, $15 \%$ Gasoline; M100 = Neat Methanol; E85 = mixture of $85 \%$ Ethanol, 15\% Gasoline; E95 = mixture of $95 \%$ Ethanol, $5 \%$ Gasoline.

Source: 1993 Estimates and 1995 Projections: Federal: Science Applications International Corporation, spreadsheet prepared for the Energy Information Administration, (McLean, VA, August 1994). Non-Federal: Science Applications International Corporation, "Alternative Transportation Fuels and Vehicles Data Development," unpublished final report prepared for the Energy Information Administration, (McLean, VA, August 1994).

continued distribution limitations. Domestic MTBE production capacity, on the other hand, grew 68 percent from January 1, 1992, to January 1, $1994 .{ }^{4}$

Aggregate demand for oxygenates is expected to increase about 50 percent on an MTBE-equivalent basis from 1993 to 1995.5 Oxygenate demand in 1995 will be filled mainly by domestic MTBE and ethanol production, supplemented by small volumes of ethyl tertiary butyl ether (ETBE), tertiary amyl methyl ether (TAME), MTBE imports, and MTBE inventories. ${ }^{6}$ The beginning of the reformulated gasoline requirements, which include a minimum oxygen requirement year round, is the primary reason for the expected increase in 1995. In 1995, reformulated gasoline is expected to comprise almost 35 percent of motor gasoline demand. Altogether, oxygenates are expected to make up about 4 percent of total gasoline demand. In addition to consumption for reformulated gasoline purposes, MTBE is also consumed for octane blending purposes and spillovers.
Consumption of MTBE is expected to increase dramatically between 1993 and 1995. During the same period, consumption of ethanol used as a fuel additive is expected to increase by 111 million gasoline-equivalent gallons (almost 15 percent). These estimates do not take into account the renewable oxygenate standard (ROS), which was recently promulgated by the Environmental Protection Agency (See box on the Renewable Oxygenate Standard). The shift toward renewable-based ethanol and ETBE that would result from the implementation of the ROS is expected to be minimal in 1995.

\section{Regional Distribution of Alternative and Oxygenate Fuel Consumption for 1993 and 1995}

\section{Alternative Fuels}

Alternative fuels consumption distribution by private, and State and local governments is divided according to Census Regions for 1993 and 1995 


\section{The Environmental Protection Agency's Renewable Oxygenate Standard}

The Renewable Oxygenate Standard (ROS), mandated by the Environmental Protection Agency (EPA) in June of 1994, requires that 30 percent of the oxygen content of reformulated gasoline come from renewable oxygenates. This requirement applies year-round to all refiners or importers of reformulated gasoline, as well as suppliers of the gasoline to be blended with oxygenates.

The requirement goes into effect December 1, 1994. A phase-in of the 30 percent requirement will occur to allow for adequate leadtime to establish blending and storage systems. The EPA is mandating that 15 percent of the oxygen requirement be met from renewable sources in 1995, and that the full 30 percent be met from renewable sources in 1996 and thereafter. Also, to provide maximum flexibility for refiners and fuel importers, there are provisions for averaging and credit trading among refiners and importers of reformulated gasoline.

According to the EPA, the ROS program is designed to maximize the energy and other benefits from the reformulated gasoline program mandated as part of the Clean Air Act Amendments of 1990 (CAAA) while obtaining significant emission reductions in ozone-forming volatile organic compounds (VOC's) and toxic air pollutants in nonattainment areas. The CAAA mandates certain requirements for the reformulated gasoline program, including a minimum oxygen content of 2.0 by weight percent and minimum performance standards for emission reductions. To ensure that the ozone benefits of the reformulated program are unaffected by ROS, the EPA ruled that during the VOC control period (the summer months) only renewable oxygenates that do not exhibit volatility-related commingling effects when mixed with gasoline (e.g. ETBE) would receive renewable oxygenates credit. Both ETBE and ethanol are expected to be acceptable during the non-summer months.

The United States Court of Appeals for the District of Columbia Circuit issued a stay on the ROS program on September 13,1994. The court will begin hearing oral arguments from all parties on the first available date following the January 12, 1995, filing on Final Briefs. Consequently, the requirement for the use of renewable oxygenates will not be in effect at the January 1,1995, start-up of the reformulated gasoline program. The long-term effect is still unresolved. However, the main results pertaining to reformulated gasoline supply and demand are unaffected by which oxygenate is added to reformulated gasoline and therefore are unchanged by this event.

(Table 15 and 16). Regional consumption distribution for Federal vehicles is unknown and therefore is not included. However, Federal AFV's represented about 3 percent of the total AFV's in 1993.

The regional distribution of LPG consumption is not expected to change between 1993 and 1995 (Table 15). Similar to the regional distribution of LPGfueled vehicles (refer to Tables 6 and 7), the largest amount of transportation LPG will be consumed in the South, followed by the West then the Midwest. The largest regional consumption of CNG in 1993 was in the South (35 percent) followed by the West (33 percent). This trend is projected to continue in 1995. As in 1993, almost all LNG will be consumed in the South in 1995.

From 1993 to 1995, the regional consumption patterns of alcohol fuels are not expected to vary. The majority of ethanol consumption will remain in the
Midwest, and the Northeast will continue to be the smallest consumer (Table 16). The West will continue to be the dominant consumer of methanol. In 1993, the West had a 97-percent share of M85 and a 96-percent share of M100 consumption. The West Region's 1995 share is expected to remain about the same at 99 percent for M85 and 93 percent for M100.

\section{Oxygenates}

The regional distribution of ethanol used as an oxygenate in 1993 was similar to the distribution in 1992. In 1992, about 70 percent of ethanol was consumed in the Midwest, 17 percent in the South, 12 percent in the West, and less than 1 percent in the Northeast. ${ }^{8}$ The Midwest accounted for most of the U.S. annual ethanol consumption due to the presence of most of the Country's alcohol production capacity in that area. Midwestern alcohol producers take advantage of the availability of corn 
Table 15. Consumption of Liquefied Petroleum Gases and Natural Gas by Region, 1993 and 1995 (Percent share)

\begin{tabular}{|c|c|c|c|c|c|c|}
\hline \multirow[b]{2}{*}{ Census Region } & \multicolumn{3}{|c|}{1993} & \multicolumn{3}{|c|}{1995} \\
\hline & LPG & CNG & LNG & LPG & CNG & LNG \\
\hline Northeast $\ldots \ldots \ldots$ & 11 & 15 & 0 & 11 & 15 & 0 \\
\hline South $\ldots \ldots \ldots \ldots$ & 34 & 35 & 98 & 34 & 35 & 92 \\
\hline Midwest $\ldots \ldots \ldots \ldots$ & 26 & 17 & 1 & 26 & 17 & 2 \\
\hline West $\ldots$ & 29 & 33 & 1 & 29 & 33 & 6 \\
\hline Total . & 100 & 100 & 100 & 100 & 100 & 100 \\
\hline
\end{tabular}

Notes: - Includes consumption by privately owned, State and local government vehicles only, and does not include Federally owned vehicles. - Totals may not equal sum of components due to rounding. Fuel terms are defined in the Glossary. LPG = Liquefied Petroleum Gases; CNG = Compressed Natural Gas; LNG = Liquefied Natural Gas.

Source: 1993 Estimates and 1995 Projections: Science Applications International Corporation, "Alternative Transportation Fuels and Vehicles Data Development," unpublished final report prepared for the Energy Information Administration, (McLean, VA, August 1994).

feedstocks and reduced transit expenses for shipping their products to resellers, blenders, and retailers. Another factor influencing regional ethanol consumption patterns is the existence of alcohol fuel tax exemptions or credits in some States.

In the Northeast, relatively little grain production and few State tax credit programs exist for ethanol. In the West, fuel distribution is difficult and freight costs generally lower the cost-competitiveness of ethanol relative to other areas of the United States.?
More ethanol consumption in the Northeast in 1995 is possible if the ROS is implemented (see box above on the ROS).

Methyl tertiary butyl ether consumption is more evenly distributed by region. It is usually produced in the same location as gasoline, then added to gasoline at refineries, and shipped through the established nationwide gasoline transportation network. Regional demand will be mostly affected by the location of CAAA nonattainment regions, which are required to use oxygenated and reformulated gasoline.

Table 16. Consumption of Alcohol Fuels by Region, 1993 and 1995 (Percent share)

\begin{tabular}{|c|c|c|c|c|c|c|c|c|}
\hline \multirow[b]{2}{*}{ Census Region } & \multicolumn{4}{|c|}{1993} & \multicolumn{4}{|c|}{1995} \\
\hline & M85 & M100 & E85 & E95 & M85 & $M 100$ & E85 & E95 \\
\hline Northeast & 1 & 2 & * & 0 & 1 & 5 & $*$ & 0 \\
\hline South $\ldots \ldots \ldots$ & 1 & 2 & 0 & 1 & * & 2 & 1 & * \\
\hline Midwest . . . . & 1 & 0 & 90 & 99 & * & 0 & 94 & 100 \\
\hline West $\ldots \ldots \ldots \ldots$ & 97 & 96 & 9 & 0 & 99 & 93 & 5 & 0 \\
\hline Total $\ldots \ldots \ldots \ldots$ & 100 & 100 & 100 & 100 & 100 & 100 & 100 & 100 \\
\hline
\end{tabular}

- Less than 0.5 percent rounded to 0 .

Notes: - Includes consumption by privately owned, State and local government vehicles only, and does not include Federally owned vehicles. - Totals may not equal sum of components due to independent rounding. - Fuel terms are defined in the Glossary. M85 $=$ mixture of $85 \%$ Methanol, 15\% Gasoline; M100 = Neat Methanol; E85 = mixture of 85\% Ethanol, 15\% Gasoline; E95 = mixture of $95 \%$ Ethanol, 5\% Gasoline. Source: 1993 Estimates and 1995 Projections: Science Applications International Corporation, "Alternative Transportation Fuels and Vehicles Data Development," unpublished final report prepared for the Energy Information Administration, (McLean, VA, August 1994). 


\section{Notes}

${ }^{1}$ Data on vehicle ownership and weight class for oxygenates are not available.

${ }^{2}$ Energy Information Administration, Alternatives to Traditional Transportation Fuels: An Overview, DOE/EIA-05850 (Washington, DC, June 1994), p. 22.

${ }^{3}$ Charles Dale, "The Economics of the Clean Air Act Amendments of 1990: Review of the 1992-1993 Oxygenated Motor Gasoline Season," in Energy Information Administration, Petroleum Supply Monthly, DOE/EIA-0109993/07, (Washington, DC, July 1993), p.xvi.

'Tancred Lidderdale, "Demand, Supply, and Price Outlook for Reformulated Motor Gasoline 1995", in Energy Information Administration Monthly Energy Review, DOE/EIA - 00356(94/07), (Washington, DC, July 1994), p 8.

${ }^{5} \mathrm{MTBE}$-equivalent units are used to compare oxygenates based on their oxygen content. One gallon ethanol = 1.95 gallons MTBE-equivalent gallons.

${ }^{6}$ Tancred Lidderdale, "Demand, Supply, and Price Outlook for Reformulated Motor Gasoline 1995", in Energy Information Administration Monthly Energy Review, 1994, p 7.

'Tancred Lidderdale, "Demand, Supply, and Price Outlook for Reformulated Motor Gasoline 1995", in Energy Information Administration Monthly Energy Review, 1994, p 1.

${ }^{8}$ Energy Information Administration, Estimates of U.S. Biomass Energy Consumption 1992, DOE/EIA-0548(92) (Washington, DC, May 1994), p.26.

${ }^{9}$ Energy Information Administration, Estimates of U.S. Biomass Energy Consumption 1992, p.28. 


\section{Greenhouse Gas Emissions}

\section{Background}

Greenhouse gases are of concern due to their potential worldwide climate impact, known as the "greenhouse effect." An explanation of the greenhouse effect is provided in Appendix C. ${ }^{1}$

There are many gases that contribute to the greenhouse effect; some of the gases that contribute most directly to the greenhouse effect are water vapor $\left(\mathrm{H}_{2} \mathrm{O}\right)$, carbon dioxide $\left(\mathrm{CO}_{2}\right)$, methane $\left(\mathrm{CH}_{4}\right)$, and nitrous oxide $\left(\mathrm{N}_{2} \mathrm{O}\right)^{2}$ Other gases, such as carbon monoxide $(\mathrm{CO})$, nitrogen oxides $\left(\mathrm{NO}_{x}\right)$, and nonmethane organic compounds (NMOC's), ${ }^{3}$ do not have a significant direct impact on the greenhouse effect, but have an important indirect impact as precursors to other greenhouse gases. In this report, the term greenhouse gas refers to gases that contribute substantially either directly or indirectly to the greenhouse effect.

In response to Section 503(a)(4) of the Energy Policy Act (EPACT), this chapter provides: (1) an assessment of the most comprehensive study on the subject published to date, Emissions of Greenhouse Gases from the Use of Transportation Fuels and Electricity (which will be referred to as the "DeLuchi Report" in this chapter ${ }^{4}$ ); (2) qualitative comparisons of greenhouse gases emissions from gasoline, alternative and replacement fuels, on a total fuel cycle basis; and (3) the Energy Information Administrations' (EIA's) strategy for providing future emission estimates. Information regarding the projected fuel cycle and energy efficiency assumptions behind these projections may be found in Appendix D.

Several methods can be used to estimate total greenhouse gas emissions. All methods require many pieces of information plus a wide variety of assumptions. These data and assumptions can have significant impact on the results. To avoid misinterpreting the results of different studies, it is important to understand the data and assumptions used.

After reviewing numerous studies, the EIA has concluded that the best published basis upon which to build future emissions analysis is the DeLuchi Report. The DeLuchi Report is reasonably comprehensive and detailed in its methodology for estimating transportation fuel greenhouse gas emissions in the late 1990s. It pays particular attention to examining the strengths and weaknesses of the data and assumptions. Post-publication work has continued on this approach, with the most recent results being made available just prior to this report. An analysis performed by the Environmental Protection Agency (EPA), which provided an additional compilation of assumptions and parameters, was also examined. ${ }^{5}$ Because this work is only in preliminary draft form, it was not considered as the basis for EIA's analysis.

\section{Emission Estimates}

Greenhouse gas emission estimates from the DeLuchi Report are summarized for several transportation fuels in order to illustrate the influence of the various fuel cycle stages on overall fuel cycle emissions. The emissions are displayed in grams per mile for dedicated, light-duty vehicles burning these fuels. ${ }^{6}$ Before these emission estimates were made, the fuel cycle was defined and energy balances established (Appendix D). Final emission estimates of different greenhouse gases produced are a function of the types of fuels assumed in a given fuel cycle stage, the technologies involved, and the associated amount of that fuel used (i.e., the energy efficiency).

The estimates are also affected by the assumed relative efficiencies of the vehicles using the different fuel types. For example, the DeLuchi Report assumes a gasoline vehicle efficiency of 30 miles per gallon. This is probably slightly higher than the average annual vehicle efficiency today. If the assumption was changed to a lower value and the relative efficiencies of the other vehicles did not change, the values in the emissions tables would shift upwards by the ratio of the higher to the lower efficiencies. The relative rankings among fuels, however, would not change significantly.

According to the DeLuchi Report, $\mathrm{CO}_{2}$ emissions are lowest for CNG and LPG (Table 17). Compressed natural gas produces the lowest emissions at 244 grams/mile, closely followed by LPG at 266 grams $/$ mile. There are two reasons for this result. First, neither CNG or LPG require conversion nor much processing in order to be used as a transportation fuel. For the other fuels, the least energyefficient stage in the fuel cycle, excluding the vehicle, is the conversion stage. Second, both of 
Table 17. Carbon Dioxide $\left(\mathrm{CO}_{2}\right)$ Emissions per Vehicle Mile (Grams)

\begin{tabular}{|c|c|c|c|c|c|c|}
\hline Fuel Cycle Stage & $\begin{array}{l}\text { Unleaded } \\
\text { Gasoline }\end{array}$ & RFG & $\begin{array}{c}\text { Methanol } \\
\text { from } \\
\text { Natural Gas }\end{array}$ & $\begin{array}{l}\text { Ethanol } \\
\text { from Corn }\end{array}$ & $\begin{array}{l}\text { Compressed } \\
\text { Natural Gas }\end{array}$ & $\begin{array}{l}\text { LPG from } \\
\text { Oil \& Gas }\end{array}$ \\
\hline $\mathrm{CO}_{2}$ from Natural Gas Wells & 0.0 & 0.0 & 6.3 & 0.0 & 4.5 & 2.9 \\
\hline Gas Leaks and Flares ${ }^{1}$ & 3.5 & 3.0 & 0.0 & 0.0 & 0.0 & 0.9 \\
\hline Fertilizer Manufacture . . & 0.0 & 0.0 & 0.0 & 57.0 & 0.0 & 0.0 \\
\hline $\mathrm{N}_{2} \mathrm{O}, \mathrm{NO}_{x}, \mathrm{CO}_{2}$ from Fertilizer. & 0.0 & 0.0 & 0.0 & 0.0 & 0.0 & 0.0 \\
\hline Feedstock Recovery . . . . & 10.0 & 8.5 & 15.9 & 10.8 & 6.2 & 6.4 \\
\hline Feedstock Transmission & 8.7 & 7.4 & 4.8 & 13.7 & 0.0 & 2.2 \\
\hline Fuel Production & 47.8 & 58.7 & 62.5 & 226.1 & 5.4 & 10.0 \\
\hline Fuel Distribution & 4.9 & 4.8 & 23.2 & 15.9 & 8.7 & 5.7 \\
\hline Compression or Liquefaction & 0.0 & 0.0 & 0.0 & 0.0 & 18.7 & 0.0 \\
\hline Subtotal $\ldots \ldots \ldots \ldots \ldots$ & 74.9 & 82.4 & 112.7 & 323.5 & 43.5 & 28.1 \\
\hline Vehicle & 284.4 & 277.3 & 222.0 & 2.0 & 200.9 & 238.2 \\
\hline Total & 359.3 & 359.7 & 334.7 & 325.5 & 244.4 & 266.3 \\
\hline
\end{tabular}

' Assumes that flared gas is burned completely to $\mathrm{CO}_{2}$ and $\mathrm{H}_{2} \mathrm{O}$ with no $\mathrm{CH}_{4}, \mathrm{NMOC}, \mathrm{CO}, \mathrm{NO}_{x}$, or $\mathrm{N}_{2} \mathrm{O}$.

Notes: - Table was derived using a 30 mile per gallon gasoline efficiency vehicle. Emissions from manufacturing the vehicles are not included. -LPG = Liquefied Petroleum Gases; RFG = Reformulated Gasoline; $\mathrm{N}_{2} \mathrm{O}=$ Nitrous Oxide; $\mathrm{NO}_{x}=$ Nitrogen Oxide.

Source: Derived from greenhouse gas emissions spreadsheet provided to the Energy Information Administration, July 1994. Spreadsheet is an unpublished revision of: Argonne National Laboratory, Center for Transportation Research, Emissions of Greenhouse Gases from the Use of Transportation Fuels and Electricity, ANL/ESD/TM-22, prepared by Dr. Mark DeLuchi, Vol. 1 (November 1991) and Vol. 2 (November 1993).

these fuels have a very low carbon-to-hydrogen ratio relative to the other fuels shown. Since they contain more hydrogen atoms per carbon atom than do the other fuels, and a unit weight of hydrogen produces more energy than a unit weight of carbon, both $\mathrm{CNG}$ and LPG produce less $\mathrm{CO}_{2}$ than other fuels as a percentage of energy consumed.

A major factor driving $\mathrm{CO}_{2}$ emissions for alcohols is the low energy efficiency in the conversion (i.e., fuel production) stage of these fuels (see Appendix D). The conversion stage generates 19 percent of total $\mathrm{CO}_{2}$ emissions for the methanol fuel cycle and 69 percent for the ethanol fuel cycle. Unleaded gasoline emissions of $\mathrm{CO}_{2}$ in the conversion stage are 13 percent of total $\mathrm{CO}_{2}$ emissions, while $\mathrm{CNG}$ processing emissions of $\mathrm{CO}_{2}$ are only about two percent of total $\mathrm{CNG}$ fuel cycle $\mathrm{CO}_{2}$ emissions. Of all the fuels, the alcohols produce the largest volume of $\mathrm{CO}_{2}$ emissions prior to vehicle combustion. In the fuel production stage, the DeLuchi Report indicates that 1.5 million British Thermal Units (Btu's) of energy are required to produce one million Btu's of methanol (see Appendix D). Ethanol's energy conversion efficiency is even lower, partially due to the assumed use of coal as a boiler fuel in this example. Coal has a low heat content and a high $\mathrm{CO}_{2}$ emission rate relative to other fuels because of its low hydrogen content. However, the use of coal in the DeLuchi Report is offset somewhat by high ethanol conversion efficiency assumptions based on new plant technology.

The overall picture changes when the vehicle combustion stage is considered. Alcohol fuels have significant advantages over unleaded gasoline at this point. Methanol gains its advantages primarily because methanol vehicles are assumed to be more efficient than gasoline vehicles. The DeLuchi Report assumes an efficiency improvement of about 15 percent for advanced, dedicated, non-lean burn M100 vehicles meeting the $0.4 \mathrm{grams} / \mathrm{mile} \mathrm{NO}_{\mathrm{x}}$ standard. The $\mathrm{CO}_{2}$ emissions from alcohols and gasoline are close enough in the DeLuchi Report to illustrate the importance of the underlying assumptions. For example, if the efficiencies of the vehicles were equal, methanol vehicle emissions would increase to $255 \mathrm{grams} / \mathrm{mile}$, and total methanol emissions would increase to 368 
grams/mile, which is higher than the 359 grams/mile for gasoline.

Assumptions regarding ethanol production methods can make a big difference in emission estimates, given the large impact ethanol production has on the total $\mathrm{CO}_{2}$ emissions resulting from ethanol. The Deluchi Report notes that a 20-to-30-percent thermal efficiency improvement for an ethanol engine over a gasoline engine could be achieved with high compression and cleaner operation. However, the DeLuchi Report uses a lesser gain due to other considerations. For example, there are studies that show lean burn engines increase $\mathrm{NO}_{x}$ emissions, so DeLuchi assumes that the full advantage of the thermal efficiency potential cannot be realized. In addition to thermal efficiencies, the Deluchi Report considers weight differences between vehicles. The release of $\mathrm{CO}_{2}$ into the atmosphere when ethanol is burned is substantially offset by the assumption that a similar quantity of $\mathrm{CO}_{2}$ will be removed by the next ethanol crop being grown. The ethanol carbon sequestering credit is taken at the vehicle level.
That is, the $\mathrm{CO}_{2}$ emitted from the ethanol fuel combustion is assumed to be removed by the next crop of corn being grown. The small $\mathrm{CO}_{2}$ emissions shown for ethanol are due to lubricants and other nonethanol factors. Unleaded and reformulated gasoline result in roughly the same $\mathrm{CO}_{2}$ emissions in the DeLuchi Report. Although vehicle $\mathrm{CO}_{2}$ emissions from reformulated gasoline are lower than from unleaded gasoline, the additional $\mathrm{CO}_{2}$ emissions from the production of reformulated gasoline (including the production of the oxygenate MTBE) offset lower vehicle $\mathrm{CO}_{2}$ emissions.

Total methane emissions vary from a low of 0.241 grams per vehicle-mile for LPG to 1.559 for CNG (Table 18). As vehicle and refueling technologies change and release fewer greenhouse gases, the $\mathrm{CH}_{4}$ emissions from the various fuels (especially $\mathrm{CNG}$ ) will decrease. $\mathrm{Most}^{\mathrm{CH}_{4}}$ emissions prior to combustion come from leakages in the feedstock production process. According to the DeLuchi Report, the highest $\mathrm{CH}_{4}$ emissions are produced by the CNGfueled vehicle. However, refueling emissions and

Table 18. Methane $\left(\mathrm{CH}_{4}\right)$ Emissions per Vehicle Mile (Grams)

\begin{tabular}{|c|c|c|c|c|c|c|}
\hline Fuel Cycle Stage & $\begin{array}{l}\text { Unleaded } \\
\text { Gasoline }\end{array}$ & RFG & $\begin{array}{c}\begin{array}{c}\text { Methanol } \\
\text { from } \\
\text { Natural Gas }\end{array} \\
\end{array}$ & $\begin{array}{l}\text { Ethanol } \\
\text { from Corn }\end{array}$ & $\begin{array}{l}\text { Compressed } \\
\text { Natural Gas } \\
\end{array}$ & $\begin{array}{l}\text { LPG from } \\
\text { Oil \& Gas }\end{array}$ \\
\hline $\mathrm{CO}_{2}$ from Natural Gas Wells & 0.000 & 0.000 & 0.000 & 0.000 & 0.000 & 0.000 \\
\hline Gas Leaks and Flares $^{1} \ldots$ & 0.178 & 0.152 & 0.367 & 0.000 & 0.490 & 0.169 \\
\hline Fertilizer Manufacture . . . . . & 0.000 & 0.000 & 0.000 & 0.100 & 0.000 & 0.000 \\
\hline $\mathrm{N}_{2} \mathrm{O}, \mathrm{NO}_{x}, \mathrm{CO}_{2}$ from Fertilizer. & 0.000 & 0.000 & 0.000 & 0.000 & 0.000 & 0.000 \\
\hline Feedstock Recovery . . . . . . & 0.016 & 0.012 & 0.003 & 0.000 & 0.001 & 0.005 \\
\hline Feedstock Transmission ... & 0.009 & 0.009 & 0.030 & 0.016 & 0.000 & 0.002 \\
\hline Fuel Production $\ldots \ldots \ldots$ & 0.062 & 0.107 & 0.037 & 0.405 & 0.001 & 0.007 \\
\hline Fuel Distribution $\ldots$ & 0.004 & 0.004 & 0.030 & 0.020 & 0.040 & 0.007 \\
\hline Compression or Liquefaction & 0.000 & 0.000 & 0.000 & 0.000 & 0.027 & 0.000 \\
\hline Subtotal $\ldots \ldots \ldots \ldots$ & 0.269 & 0.285 & 0.467 & 0.540 & 0.559 & 0.191 \\
\hline Vehicle $\ldots \ldots \ldots \ldots \ldots$ & 0.050 & 0.050 & 0.030 & 0.030 & 1.000 & 0.050 \\
\hline Total $\ldots \ldots \ldots \ldots \ldots$ & 0.319 & 0.335 & 0.497 & 0.570 & 1.559 & 0.241 \\
\hline
\end{tabular}

\footnotetext{
${ }^{1}$ Assumes that flared gas is burned completely to $\mathrm{CO}_{2}$ and $\mathrm{H}_{2} \mathrm{O}$ with no $\mathrm{CH}_{4}, \mathrm{NMOC}, \mathrm{CO}, \mathrm{NO}_{x 1}$ or $\mathrm{N}_{2} \mathrm{O}$. Notes: -Table was derived using a 30 mile per gallon gasoline efficiency vehicle. Emissions from manufacturing the vehicles are not included. -LPG = Liquefied Petroleum Gases; RFG = Reformulated Gasoline; $\mathrm{CO}_{2}=$ Carbon Dioxide; $\mathrm{N}_{2} \mathrm{O}=\mathrm{Nitrous}_{\mathrm{O}} \mathrm{Oxide} ; \mathrm{NO}_{x}=\mathrm{Nitrogen}$ Oxide Source: Derived from greenhouse gas emissions spreadsheet provided to the Energy Information Administration, July 1994. Spreadsheet is an unpublished revision of: Argonne National Laboratory, Center for Transportation Research, Emissions of Greenhouse Gases from the Use of Transportation Fuels and Electricity, ANL/ESD/TM-22, prepared by Dr. Mark DeLuchi, Vol. 1 (November 1991) and Vol. 2 (November 1993).
} 
uncombusted methane from the front end of the fuel cycle are not fully addressed under this report's assumptions. For ethanol, the emissions stem from the fuel production phase where methane is principally released from the combustion of coal, the main boiler fuel.

Nitrous oxide emissions are virtually the same for all fuels except ethanol (Table 19). In the case of ethanol, $\mathrm{N}_{2} \mathrm{O}$ emissions arise as a result of fertilizer used to grow corn, the main ethanol feedstock in the United States.

Nitrogen dioxide emissions are about the same for all fuels except ethanol and methanol (Table 20). The methanol fuel production stage emits almost twice as much $\mathrm{NO}_{2}$ as the entire fuel cycle up to vehicle combustion. Nitrogen dioxide emissions from ethanol are higher than $\mathrm{NO}_{2}$ emissions from other fuels due to higher emissions from both the production and fertilizer stages.
Carbon monoxide emissions (Table 21) are the result of incomplete fuel combustion. They are at their peak when fuel is combusted in a cold vehicle engine with a cold catalytic converter. Carbon monoxide emissions are lowest by far for CNG because CNG is the least chemically complex of all the fuels and is in a gaseous state (i.e., CNG requires no change of state from liquid to gas prior to burning and therefore combusts almost completely upon ignition, even when cold). Reformulated gasoline, with a higher oxygen content than conventional gasoline, has lower $\mathrm{CO}$ emissions than conventional gasoline.

Tables 17 through 21 show that $\mathrm{CO}_{2}$ emissions in grams per mile are much larger than the other greenhouse gas emissions. However, these other gases have a greater warming effect on a gram-forgram basis than $\mathrm{CO}_{2}$, and are generally given a higher warming potential weight than $\mathrm{CO}_{2}$. When greenhouse gas emissions are aggregated using $\mathrm{CO}_{2}$

Table 19. Nitrous Oxide $\left(\mathrm{N}_{2} \mathrm{O}\right)$ Emissions per Vehicle Mile (Grams)

\begin{tabular}{|c|c|c|c|c|c|c|}
\hline Fuel Cycle Stage & $\begin{array}{l}\text { Unleaded } \\
\text { Gasoline }\end{array}$ & RFG & $\begin{array}{c}\text { Methanol } \\
\text { from } \\
\text { Natural Gas }\end{array}$ & $\begin{array}{l}\text { Ethanol } \\
\text { from Corn }\end{array}$ & $\begin{array}{l}\text { Compressed } \\
\text { Natural Gas }\end{array}$ & $\begin{array}{l}\text { LPG from } \\
\text { Oil \& Gas }\end{array}$ \\
\hline $\mathrm{CO}_{2}$ from Natural Gas Wells & 0.000 & 0.000 & 0.000 & 0.000 & 0.000 & 0.000 \\
\hline Gas Leaks and Flares ${ }^{\prime}$ & 0.000 & 0.000 & 0.000 & 0.000 & 0.000 & 0.000 \\
\hline Fertilizer Manufacture . . . & 0.000 & 0.000 & 0.000 & 0.002 & 0.000 & 0.000 \\
\hline $\mathrm{N}_{2} \mathrm{O}, \mathrm{NO}_{x}, \mathrm{CO}_{2}$ from Fertilizer. & 0.000 & 0.000 & 0.000 & 0.327 & 0.000 & 0.000 \\
\hline Feedstock Recovery & 0.000 & 0.000 & 0.001 & 0.000 & 0.000 & 0.000 \\
\hline Feedstock Transmission . . . & 0.000 & 0.000 & 0.000 & 0.001 & 0.000 & 0.000 \\
\hline Fuel Production & 0.004 & 0.004 & 0.003 & 0.010 & 0.000 & 0.000 \\
\hline Fuel Distribution & 0.000 & 0.000 & 0.001 & 0.001 & 0.000 & 0.001 \\
\hline Compression or Liquefaction & 0.000 & 0.000 & 0.000 & 0.000 & 0.001 & 0.000 \\
\hline Subtotal $\ldots \ldots \ldots \ldots$ & 0.005 & 0.005 & 0.005 & 0.340 & 0.002 & 0.002 \\
\hline Vehicle & 0.050 & 0.050 & 0.050 & 0.050 & 0.050 & 0.050 \\
\hline Total & 0.055 & 0.055 & 0.055 & 0.390 & 0.052 & 0.052 \\
\hline
\end{tabular}

' Assumes that flared gas is burned completely to $\mathrm{CO}_{2}$ and $\mathrm{H}_{2} \mathrm{O}$ with no $\mathrm{CH}_{4}, \mathrm{NMOC}, \mathrm{CO}, \mathrm{NO}_{x}$, or $\mathrm{N}_{2} \mathrm{O}$.

Notes: -Table was derived using a 30 mile per gallon gasoline efficiency vehicle. Emissions from manufacturing the vehicles are not included. -LPG = Liquefied Petroleum Gases; RFG = Reformulated Gasoline; $\mathrm{CO}_{2}=$ Carbon Dioxide; $\mathrm{NO}_{\mathrm{x}}=\mathrm{Nitrogen}$ Oxide

Source: Derived from greenhouse gas emissions spreadsheet provided to the Energy Information Administration, July 1994. Spreadsheet is an unpublished revision of: Argonne National Laboratory, Center for Transportation Research, Emissions of Greenhouse Gases from the Use of Transportation Fuels and Electricity, ANL/ESD/TM-22, prepared by Dr. Mark DeLuchi, Vol. 1 (November 1991) and Vol. 2 (November 1993). 
Table 20. Nitrogen Dioxide $\left(\mathrm{NO}_{2}\right)$ Emissions Per Vehicle Mile (Grams)

\begin{tabular}{|c|c|c|c|c|c|c|}
\hline Fuel Cycle Stage & $\begin{array}{l}\text { Unleaded } \\
\text { Gasoline }\end{array}$ & RFG & $\begin{array}{c}\text { Methanol } \\
\text { from } \\
\text { Natural Gas }\end{array}$ & $\begin{array}{l}\text { Ethanol } \\
\text { from Corn }\end{array}$ & $\begin{array}{l}\text { Compressed } \\
\text { Natural Gas }\end{array}$ & $\begin{array}{l}\text { LPG from } \\
\text { Oil \& Gas }\end{array}$ \\
\hline $\mathrm{CO}_{2}$ from Natural Gas Wells & 0.000 & 0.000 & 0.000 & 0.000 & 0.000 & 0.000 \\
\hline Gas Leaks and Flares ${ }^{1} \ldots$ & 0.000 & 0.000 & 0.000 & 0.000 & 0.000 & 0.000 \\
\hline Fertilizer Manufacture & 0.000 & 0.000 & 0.000 & 0.476 & 0.000 & 0.000 \\
\hline $\mathrm{N}_{2} \mathrm{O}, \mathrm{NO}_{\mathrm{x}}, \mathrm{CO}_{2}$ from Fertilizer. & 0.000 & 0.000 & 0.000 & 0.210 & 0.000 & 0.000 \\
\hline Feedstock Recovery & 0.038 & 0.033 & 0.026 & 0.045 & 0.013 & 0.018 \\
\hline Feedstock Transmission .... & 0.052 & 0.045 & 0.037 & 0.057 & 0.000 & 0.013 \\
\hline Fuel Production & 0.090 & 0.119 & 0.380 & 0.560 & 0.006 & 0.016 \\
\hline Fuel Distribution & 0.022 & 0.022 & 0.130 & 0.070 & 0.054 & 0.023 \\
\hline Compression or Liquefaction & 0.000 & 0.000 & 0.000 & 0.000 & 0.045 & 0.000 \\
\hline Subtotal .............. & 0.202 & 0.219 & 0.574 & 1.417 & 0.119 & 0.070 \\
\hline Vehicle & 0.450 & 0.450 & 0.450 & 0.450 & 0.450 & 0.450 \\
\hline Total & 0.652 & 0.669 & 1.024 & 1.867 & 0.569 & 0.520 \\
\hline
\end{tabular}

${ }^{1}$ Assumes that flared gas is burned completely to $\mathrm{CO}_{2}$ and $\mathrm{H}_{2} \mathrm{O}$ with no $\mathrm{CH}_{4}, \mathrm{NMOC}, \mathrm{CO}, \mathrm{NO}_{x}$, or $\mathrm{N}_{2} \mathrm{O}$.

Notes: $\cdot$ Table was derived using a 30 mile per gallon gasoline efficiency vehicle. Emissions from manufacturing the vehicles are not included. -LPG = Liquefied Petroleum Gases; RFG = Reformulated Gasoline; $\mathrm{CO}_{2}=$ Carbon Dioxide; $\mathrm{N}_{2} \mathrm{O}=\mathrm{Nitrous}$ Oxide; $\mathrm{NO}_{\mathrm{x}}=\mathrm{Nitrogen}$ Oxide Source: Derived from greenhouse gas emissions spreadsheet provided to the Energy Information Administration, July 1994. Spreadsheet is an unpublished revision of: Argonne National Laboratory, Center for Transportation Research, Emissions of Greenhouse Gases from the Use of Transportation Fuels and Electricity, ANL/ESD/TM-22, prepared by Dr. Mark DeLuchi, Vol. 1 (November 1991) and Vol. 2 (November 1993).

equivalency factors (Appendix $\mathrm{C}$ ), the relative ranking among the fuels for global warming impact stays the same. This is due to the small quantities of emissions of other gases relative to $\mathrm{CO}_{2}$. The EIA has chosen not to use $\mathrm{CO}_{2}$ equivalent factors due to the associated uncertainties (Appendix D).

The ATTF Overview provided a qualitative table (reproduced as Table 22) displaying relative emission results. This table was developed by drawing on the opinions of experts to assess relative emission levels between conventional gasoline and replacement fuels. Expert judgement was supplied by the Environmental Protection Agency, Office of Mobile Sources, and their referrals. While the relative emissions are consistent with those of the DeLuchi Report displayed earlier in this chapter, there are some differences. Discrepancies among studies and the frequent inability to resolve differences are reasons that an independent, documented analysis is needed.

\section{Direction of Future Greenhouse Gas Emission Estimates}

To totally fulfill the Section 503 requirements, a complete spectrum of greenhouse gas emission estimates in grams per mile is needed for the total fuel cycle for each fuel. These etimates would then be applied to the number of vehicles to derive total emissions. Estimating fuel cycle greenhouse gas emissions is complex. Conclusions of various studies differ as a result of using different data, assumptions, and methodologies. In addition, few studies include all greenhouse gases and all stages of the fuel cycle. Therefore, no single study fully satisfies the EPACT requirements.

To meet the EPACT Section 503 requirements, the EIA will focus on the following areas:

Types of Greenhouse Gases. Many greenhouse gases and greenhouse gas precursors will be 
Table 21. Carbon Monoxide (CO) Emissions per Vehicle Mile (Grams)

\begin{tabular}{|c|c|c|c|c|c|c|}
\hline Fuel Cycle Stage & $\begin{array}{l}\text { Unleaded } \\
\text { Gasoline }\end{array}$ & RFG & $\begin{array}{c}\text { Methanol } \\
\text { from } \\
\text { Natural Gas }\end{array}$ & $\begin{array}{l}\text { Ethanol } \\
\text { from Corn }\end{array}$ & $\begin{array}{l}\text { Compressed } \\
\text { Natural Gas }\end{array}$ & $\begin{array}{l}\text { LPG from } \\
\text { Oil \& Gas }\end{array}$ \\
\hline $\mathrm{CO}_{2}$ from Natural Gas Wells & 0.000 & 0.000 & 0.000 & 0.000 & 0.000 & 0.000 \\
\hline Gas Leaks and Flares ${ }^{1} \ldots$ & 0.000 & 0.000 & 0.000 & 0.000 & 0.000 & 0.000 \\
\hline Fertilizer Manufacture . . . . . & 0.000 & 0.000 & 0.000 & 0.119 & 0.000 & 0.000 \\
\hline $\mathrm{N}_{2} \mathrm{O}, \mathrm{NO}_{x}, \mathrm{CO}_{2}$ from Fertilizer & 0.000 & 0.000 & 0.000 & 0.000 & 0.000 & 0.000 \\
\hline Feedstock Recovery . . . . . . & 0.138 & 0.115 & 0.065 & -2.211 & 0.043 & 0.062 \\
\hline Feedstock Transmission ... & 0.021 & 0.016 & 0.017 & 0.052 & 0.000 & 0.005 \\
\hline Fuel Production & 0.075 & 0.090 & 0.009 & 0.218 & 0.002 & 0.014 \\
\hline Fuel Distribution & 0.016 & 0.016 & 0.069 & 0.054 & 0.025 & 0.019 \\
\hline Compression or Liquefaction & 0.000 & 0.000 & 0.000 & 0.000 & 0.007 & 0.000 \\
\hline Subtotal $\ldots \ldots \ldots \ldots$ & 0.250 & 0.238 & 0.160 & -1.768 & 0.077 & 0.101 \\
\hline Vehicle & 7.210 & 6.130 & 7.210 & 7.210 & 3.600 & 5.500 \\
\hline Total & 7.460 & 6.368 & 7.370 & 5.442 & 3.677 & 5.601 \\
\hline
\end{tabular}

${ }^{1}$ Assumes that flared gas is burned completely to $\mathrm{CO}_{2}$ and $\mathrm{H}_{2} \mathrm{O}$ with no $\mathrm{CH}_{4}, \mathrm{NMOC}, \mathrm{CO}, \mathrm{NO}_{x}$ or $\mathrm{N}_{2} \mathrm{O}$. Notes: -Table was derived using a 30 mile per gallon gasoline efficiency vehicle. Emissions from manufacturing the vehicles are not included. -LPG = Liquefied Petroleum Gases; RFG = Reformulated Gasoline; $\mathrm{CO}_{2}=$ Carbon Dioxide; $\mathrm{N}_{2} \mathrm{O}=\mathrm{Nitrous} \mathrm{Oxide,} \mathrm{NO}_{\mathrm{x}}=\mathrm{Nitrogen}$ Oxide Source: Derived from greenhouse gas emissions spreadsheet provided to the Energy Information Administration, July 1994. Spreadsheet is an unpublished revision of: Argonne National Laboratory, Center for Transportation Research, Emissions of Greenhouse Gases from the Use of Transportation Fuels and Electricity, ANL/ESD/TM-22, prepared by Dr. Mark DeLuchi, Vol. 1 (November 1991) and Vol. 2 (November 1993).

considered for inclusion in future analyses. Water vapor, $\mathrm{CO}_{2}, \mathrm{CH}_{4}, \mathrm{~N}_{2} \mathrm{O}, \mathrm{NO}_{2}, \mathrm{CO}$, VOC's, and other compounds that are deemed important to the global warming impact of transportation fuels will be covered.

Range of Fuel Cycles. Emissions will be estimated for more fuel-cycle combinations than most other studies currently display. For example, the emissions of more types of oxygenated gasoline (i.e., gasoline containing oxygenates other than MTBE and ethanol) will likely need to be estimated for comparison purposes. Estimation of emissions from the fuel cycles displayed in "Entire Fuel Cycle for Transportation Fuels" (Figure D1) is planned.

Fuel Cycle Characterization. Most studies draw slightly different boundaries around what is included in any given fuel cycle. Fuel cycle characterizations will be standardized so that comparisons between the different alternative fuels and gasoline can be made on a consistent basis. For example, definitions of the biomass fuel cycles seem to vary more than the other fuel cycles. Future analyses may include the impacts of land use changes on biomass production. As noted by DeLuchi, land-use changes can have a bigger impact on the greenhouse gas emissions from biomass than the growth of feedstock and manufacture of the fuel (Appendix E). Most studies, including DeLuchi's base case study, assume most $\mathrm{CO}_{2}$ released upon biomass fuel combustion is removed from the atmosphere by the next biomass crop being grown. In addition, consideration may be given to the inclusion of greenhouse gas impacts resulting from the manufacture of capital equipment needed to produce and consume the fuel.

Regional considerations. Greenhouse gas fuel cycle emission data may be developed on a regional basis to allow analysts to explore the regional impacts of different fuel cycles and of different parts of the fuel cycles. For example, fuel production sources for some fuel cycles are concentrated in some regions, 
Table 22. Total Fuel-Cycle Emissions from Gasoline and from Alternative and Replacement Fuels

\begin{tabular}{|c|c|c|c|c|c|c|c|}
\hline \multirow[b]{2}{*}{ Emissions } & \multirow{2}{*}{$\begin{array}{c}\text { From } \\
\text { Gasoline }\end{array}$} & \multicolumn{6}{|c|}{ From Altemative and Replacement Fuels, Relative to Gasoline } \\
\hline & & MTBE $^{1}$ & Ethanol ${ }^{2}$ & LPG & CNG & M85 & Electric ${ }^{3}$ \\
\hline \multicolumn{8}{|l|}{ Greenhouse Gases $^{4}$} \\
\hline Water Vapor . . . . . . . . & Yes & More & More & More & More & More & Less \\
\hline Carbon Dioxide $\left(\mathrm{CO}_{2}\right)^{5}$ & Yes & Less & Less & Less & Less & Less & ()$^{6}$ \\
\hline Methane .............. & Yes & Equal & Equal & More & More & Equal & Less \\
\hline Nitrous Oxide $\left(\mathrm{N}_{2} \mathrm{O}\right)$ & Yes & ()$^{6}$ & ()$^{6}$ & ()$^{6}$ & ()$^{6}$ & ()$^{6}$ & ()$^{6}$ \\
\hline Carbon Monoxide (CO) & Yes & Less & Equal/Less $^{7}$ & Less & Less & Equal & Less \\
\hline Nitrogen Oxides (NOx) & Yes & Equal & More/Equal ${ }^{7}$ & Equal & Equal & Equal & ()$^{6}$ \\
\hline \multicolumn{8}{|l|}{ Nonmethane Organic Compounds ${ }^{8}$} \\
\hline Methanol ...... & No & More & No & No & No & More & No \\
\hline Ethanol ..... & No & No & More & No & No & No & No \\
\hline Formaldehyde & Yes & More & More & Equal & Equal & More & Less \\
\hline Acetaldehyde $\ldots \ldots \ldots \ldots \ldots$ & Yes & Less & More & Less & Equal & Equal & Less \\
\hline Ethane $\ldots \ldots \ldots \ldots \ldots$ & Yes & Equal & Equal & Equal & Equal & Equal & Less \\
\hline Total Ozone Precursors $^{9} \ldots \ldots$ & Yes & Less & More/Less ${ }^{10}$ & Less & Less & Less & Less \\
\hline Sulfur Oxides $^{11} \ldots \ldots \ldots \ldots \ldots$ & Yes & Less & Less & No & No & Less & More \\
\hline Particulate Matter $^{12} \ldots \ldots \ldots$ & Yes & Less & Less & Less & No & No & More \\
\hline
\end{tabular}

'Consumed with the gasoline in which it was blended (e.g., oxygenated gasoline and RFG).

${ }^{2}$ Includes ethanol in oxygenated gasoline, RFG and gasohol, and ethanol as E85.

'Life-cycle emissions from electric vehicles depend on the utility boiler feedstock; these projections assume that the feedstock is mostly coal, as more than half of electricity today is generated from coal.

"Greenhouse gas emission impacts are highly dependent on the feedstock used for fuel production.

${ }^{6} \mathrm{CO}_{2}$ emissions vary widely. In some cases, emissions could be either higher or lower than gasoline, depending on the feedstock and method of production.

${ }^{6}$ Results are not provided because emissions vary widely, depending on the engine's compression, temperature, and fuel/oxygen mix.

${ }^{7}$ More for splash-blended gasohol with higher Reid vapor pressure; equal for gasohol with controlled Reid vapor pressure (not splash-blended) and for E85/E100.

${ }^{8}$ Methane and ethane are just two of hundreds of volatile organic compounds. Others, such as hydrocarbons from unburned fuel and partial combustion, are not reported here.

${ }^{9} \mathrm{Ozone}$ precursors include $\mathrm{NO}_{x}, \mathrm{CO}_{2}$, and nonmethane organic compounds.

${ }^{10} \mathrm{More}$ if splash-blended gasohol but less if specially reformulated gasohol or E85/E100.

"This category includes sulfones. While most greenhouse gases contribute to global warming, the sulfates cool the atmosphere. Among the transportation fuels, sülfur oxides are emitted mostly from diesel fuel.

${ }^{12}$ Most particulate matter emissions in the transportation sector come from diesel fuel.

Note: Fuel Terms are defined in the Glossary. MTBE = Methyl Tertiary Butyl Ether; LPG = Liquefied petroleum gases (propane); CNG $=$

Compressed Natural Gas.

Source: Compiled by the United States Environmental Protection Agency, Office of Mobile Sources, based on the following references: Chang, Tai Y., Robert H. Hammerle, Steven M. Japar, and Irving T. Salmeen, "Alternative Transportation Fuels and Air Quality," Environmental Science and Technology, Vol. 25, No. 7 (1991), pp. 1190-1197; Argonne National Laboratory, Emissions of Greenhouse Gases from the Use of Transportation Fuels and Electricity (Argonne, IL), November 1993; Sperling, Daniel, New Transportation Fuels: A Strategic Approach to Technological Change (Berkeley, CA: University of California Press), 1988; U.S. Congress, Office of Technology Assessment, Replacing Gasoline: Alternative Fuels for Light-Duty Vehicles, (September 1990); U.S. Department of Energy, Assessment of Costs and Benefits of Flexible and Alternative Fuel Use in the U.S. Transportation Sector. Technical Report 7: Environmental, Health and Safety Concerns, (October 1991).

but the vehicles using the fuel may be dispersed to a broad range of urban areas, including the ozone nonattainment regions slated to switch from conventional gasoline to reformulated gasoline.

Methodology. These general procedures for developing greenhouse gas emission estimates will be followed: fuel cycle definition including technology definitions, fuel input and efficiency estimation, vehicle efficiency estimation, and emission estimation. For example, an "averaging" rather than "incremental" analysis approach may be used because EIA wants to demonstrate the total impact alternative fuels have on the existing fuel base. Average energy efficiencies and associated emissions will change over time as old vehicles and production facilities are replaced. Future reports will consider energy efficiencies for each stage of the fuel cycle 
and unit emissions on grams-per-million-Btu-inputto-vehicle and grams-per-mile bases.

Data Improvements. Future estimates may be developed using data obtained both from literature reviews as well as from EIA data collections currently under development. The DeLuchi Report will serve as a starting point for the development of data parameters. It documents the literature search behind the data well, and illustrates one of the basic dilemmas in greenhouse gas estimation: the variations in data values needed for the estimation. Published data purporting to reflect the same parameter can vary for a number of reasons. For example, one study may have needed more accurate data than another, while another study might have used different measurement techniques. Also, standard measurement techniques do not always exist to quantify the variety of data needed for greenhouse gas emission estimations. In some cases, data may not have been measured directly, but rather were deduced from other data measurements. For example, $\mathrm{N}_{2} \mathrm{O}$ emissions data are neither readily nor uniformly available for AFV's, and what is available may be derived from theoretical estimations.

The development of emissions estimates will occur in stages. Alternatives to Traditional Transportation Fuels 1994 and subsequent annual reports will reflect the progressive steps.

\title{
Notes
}

\begin{abstract}
${ }^{1}$ Appendix $C$ provides additional discussion of the greenhouse effect and transportation greenhouse gases. A general overview discussion of these phenomenon is included in two EIA reports: Altematives to Traditional Transportation Fuels: An Overview, and Emissions of Greenhouse Gases in the United States 1985-1990.
\end{abstract}

${ }^{2}$ Chlorofluorocarbons (CFC's) are not covered in this report because vehicle CFC's are being phased out and are not relevant when considering fuel type.

3Several of these gases, e.g., $\mathrm{CO}, \mathrm{NO}_{x}$, and NMOC's, are also "criteria" pollutants regulated by the U.S. Environmental Protection Agency (EPA). Criteria pollutants from vehicles are of concern in regions designated by the EPA to be out of compliance with the attainment goals set by the Clean Air Act Amendments.

'Argonne National Laboratory, Center for Transportation Research, Emissions of Greenhouse Gases from the Use of Transportation Fuels and Electricity, ANL/ESD/TM-22, prepared by Dr. Mark DeLuchi, Vol 1 (Argonne, IL, November 1991) and Vol 2 (Argonne IL, November 1993).

${ }^{5}$ Deborah Adler, Susan L. Stefanek, David Korotney, Timothy L. Sprik, Alfernative Transportation Fuels and the Greenhouse Effect, Draft Technical Report, Office of Mobile Sources, U.S. Environmental Protection Agency, (Ann Arbor, MI: June 1992).

"Heavy-duty vehicle use of alternative fuels would usually be compared against a heavy-duty vehicle using diesel fuel. 


\section{Appendix A}

\section{U.S. Census Region Map}

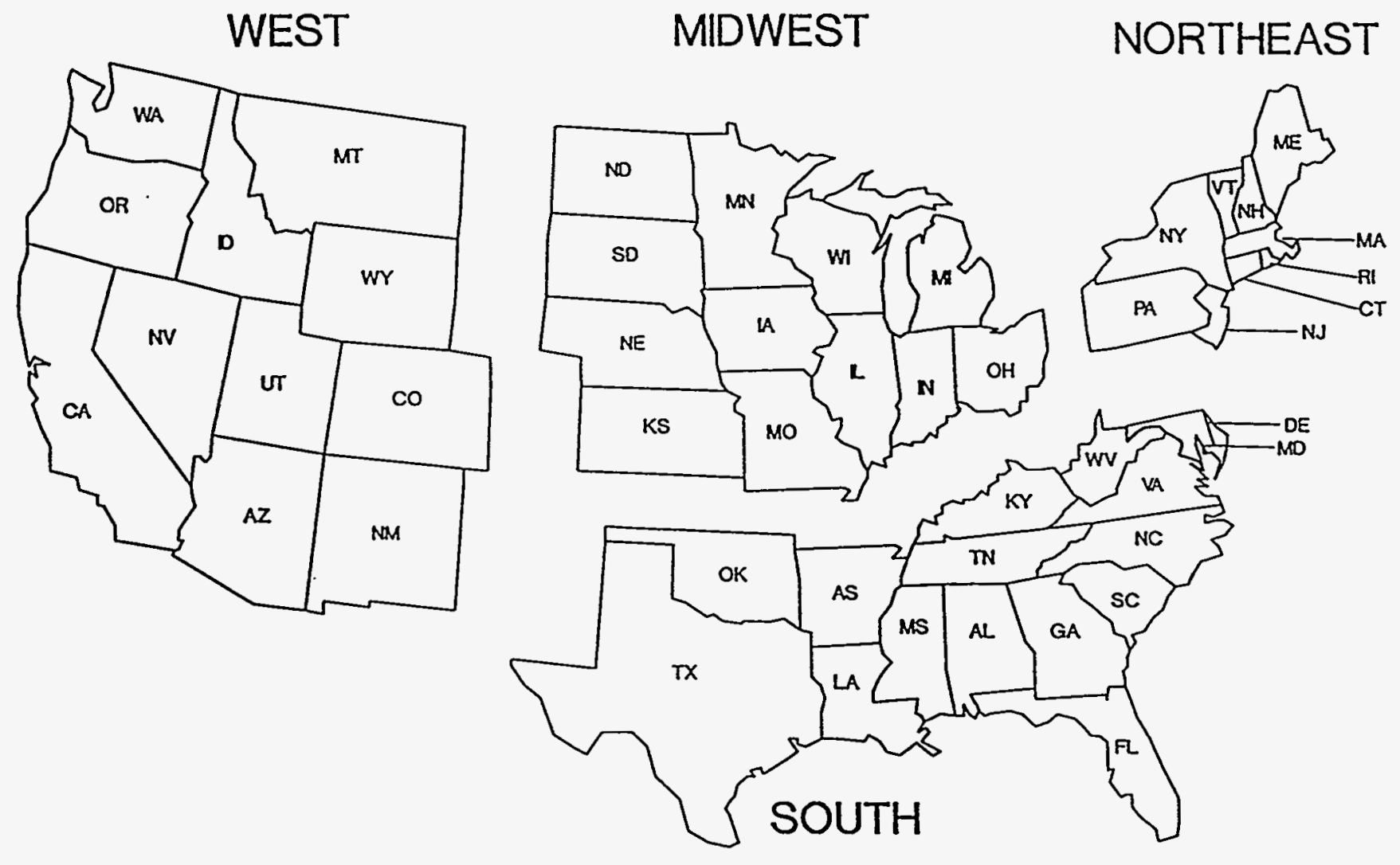

Source: U.S. Department of Commerce, Bureau of the Census. 


\section{Appendix B}

\section{Estimation Methods and Data Quality}

\section{Estimation Methods}

Estimation methods and data quality issues for alternative fueled vehicle (AFV) inventories and fuel consumption are presented in this appendix. The data estimation methods employed for this report vary by vehicle ownership category (Federal Government, State and local government fleets, and privately owned AFV's) and fuel type.

\section{Alternative Fueled Vehicle Inventory}

\section{Federal}

To estimate the number of Federal AFV's in 1992 and 1993, General Service Administration (GSA) data on AFV's leased or purchased through GSA's Automotive Commodity Center were added to data on agency-owned vehicles and agency conversions that were reported to the Department of Energy's Office of Alternative Fuels. For 1995, vehicle acquisition plans required by Executive Order 12759 were used. No retirements of AFV's were assumed for 1992 or 1993 . The GSA is expected to begin retiring its 1991 AFV fleet in 1995. These vehicles may be sold to non-Federal entities.

The GSA vehicle counts are based on records of all vehicles they leased or purchased. Vehicle counts from other Federal agencies are considered to be very accurate. Counts were obtained from all agencies known to operate substantial AFV programs. Agencies with small or remote programs, however, may not be included in the counts. Projections for 1995 are based on estimates made prior to recent announcements about vehicle availability in 1995 . Therefore, original equipment manufacturers' (OEM's) plans to make available certain vehicle types may impact these projections.

Federal vehicle data reported in Alternatives to Traditional Transportation Fuels, 1993 have been updated from the ATTF Overview. In some cases, vehicles originally reported as purchased in one year may have later been identified as purchased in a different year.

\section{Privately Owned Alternative Fueled Vehicles and State and Local Government Fleets}

Liquefied Petroleum Gases (LPG). There are no accurate government or private sector sources of onroad LPG-fueled vehicle data. A minimum level of LPG-fueled vehicles was estimated for both 1992 and 1993 from State motor fuel tax records and reported LPG consumption data. The number of LPG-fueled vehicles was estimated for each State, then aggregated to the national level. In seventeen States, AFV's could be identified from motor fuel tax information maintained by State departments of revenue or State energy offices. An estimate of average fuel consumption (gallons of LPG per vehicle) was calculated for the group of 17 States with AFV information using EIA's State-level LPG consumption data. ${ }^{1}$ For the 33 States without AFV information, the number of vehicles was then computed by dividing each State's total LPG consumption by the average number of gallons consumed per vehicle.

The number of LPG-fueled vehicles is estimated to increase at a 5.3 percent annual rate from 1993 to 1995 based on the following two factors: the 1992to-1993 rate of increase of LPG-fueled vehicles in the States where AFV's were identified from tax information, and discussions with the National Propane Gas Association, leading vehicle converters, and fuel suppliers.

Estimates of the number of LPG-fueled vehicles are highly uncertain. The implied usage of LPG per vehicle varies widely among the $17 \mathrm{AFV}$-reporting States. Inconsistent and inaccurate reporting of vehicles and fuel use is probably the primary cause of this variation. The extent of such misreporting is difficult to estimate. The vehicle counts reported here are believed to represent a lower bound estimate of the actual vehicle count. The LPG consumption data from which vehicle counts were imputed are widely believed to be underreported. These data indicate sharply declining on-road vehicle LPG consumption, but they are inconsistent with sales data for tanks, regulators, and other equipment primarily designed for on-road vehicles. 
Anecdotal evidence from conversion equipment and tank manufacturers suggests that conversions to onroad LPG-fueled vehicles number approximately 50,000 per year. Assuming that the life expectancy of an LPG-fueled fleet truck is twice that of an average fleet truck ( 7 years), the vehicle population in 1993 would be in excess of 300,000. Even this estimate may be conservative since engine life expectancy may be longer than gasoline engine life expectancy and because vehicles typically remain in service after they are retired from a fleet. Salvage and re-use of conversion equipment and aftermarket sales of LPG-fueled vehicles is common.

National Propane Gas Association data on engine fuel tank sales also suggest that the number of LPG vehicles may be underestimated by this report. Published estimates of on-road LPG vehicles vary from about 250,000 to more than 400,000 and suggest the uncertainty surrounding this question.

Compressed Natural Gas (CNG). Baseline 1992 data on the number of CNG-fueled vehicles in use were derived from a 1993 independent survey (see ATTF Overview) of natural gas suppliers and owners of CNG refueling stations. ${ }^{2}$ Respondents reported the number of vehicles served (by vehicle type and ownership) as of the end of 1992. A 1994 update of the survey provided estimates for 1993 and projections for 1995 . Since Federal vehicles were included in the survey vehicle counts, private, and State and local government vehicle counts were derived by subtracting State-level, year-end-1994 Federal vehicle counts obtained from the DOE National Renewable Energy Laboratory's AFV database. A proportional adjustment was used to estimate 1992, 1993, and 1995 Federal data.

The counts for CNG-fueled vehicles reported are more accurate and certain than LPG-fueled vehicle counts. The 1993 baseline survey covered 100 percent of the large suppliers of natural gas for CNG-fueled vehicles in the United States and a minimum of 98 percent of all suppliers of natural gas for CNG-fueled vehicles. The 1994 survey update sample consisted of a group of the original survey respondents that accounted for over 50 percent of the baseline CNG-fueled vehicles. The projections are somewhat less certain than the historical estimates. Some respondents included firm program plans in their projections, whereas others provided more speculative estimates. Some respondents suggested that the political popularity of AFV programs may cause projections to be inflated.
Liquefied Natural Gas (LNG). For 1992, 1993 and 1995 LNG-fueled vehicles' estimates are based on reported purchases or planned purchases of LNG transit buses and other vehicles. Data were obtained by an independent study of transit bus and on-road operations.

The LNG-fueled vehicle data are reasonably accurate; ownership is concentrated at transit bus companies and a few truck operations, so data collection consists primarily of identifying all LNG users. The local natural gas companies are not a source for LNG information because they do not necessarily supply the LNG. The numbers reported are believed accurate with a margin of error between five and ten percent.

Alcohol Fuels. A vehicle count for each State was obtained from State energy offices and, to a lesser extent, transportation departments, corn growers associations (ethanol only), fuel supply companies, and vehicle and engine manufacturers.

Methanol-fueled vehicle counts for all States in 1992, except California, are considered to be fairly accurate because they are based on State-by-State enumerations of relatively small vehicle fleets. Almost all methanol vehicles are operated in California, so an accurate enumeration in that State would ensure an accurate national count. California methanol vehicle counts were obtained principally from the California Energy Commission (CEC). Prior to 1994, CEC data were based on State registrations, which had some apparent inconsistencies. Starting in 1994, CEC data are based on vehicle sales by model year. Because of the CEC shift in methodology, the enumeration of vehicles reported in Alternatives to Traditional Transportation Fuels 1993 differs from the enumeration in ATTF Overview, in both total amounts and distribution. There are a larger number of private M85-fueled vehicles due to the creation and growth of large corporate fleets, including rental car companies. However, the change in methodology does not appreciably affect the overall growth rates from 1992 to 1995.

Ethanol-fueled vehicle data are as reliable as methanol-fueled vehicle data. The national total is based on an accurate enumeration in individual State governments and corn growers association demonstration vehicles. Ethanol-fueled vehicle fleets are usually small and their counts are accurate.

Electricity. Data from States with appreciable numbers of electric vehicles were collected from 
telephone contacts with State energy, transportation, or conservation offices, national electric vehicle associations (the Electric Automobile Association's State and local chapters), and electric utilities. Original equipment manufacturers, converters, and conversion kit manufacturers were also contacted.

Data on electric vehicle counts are subject to a high degree of uncertainty. Uncertainty is caused by differences in the definition of an on-road electric vehicle, by the relatively large percentage of electric vehicles that do not operate like conventional vehicles, and by possible incentives for vehicle associations to inflate estimates.

\section{Alternative Fuel Consumption}

Alternative fuel consumption was calculated using the following four basic inputs:

1) Alternative Fueled Vehicle Inventories: By vehicle fuel (e.g., M85, M100, E85), ownership (i.e., private, State and local government, Federal Government), and classification (e.g., autos, light-duty trucks, heavyduty trucks, school buses, and transit buses.)

2) Conventional Vehicle-Miles-Traveled (VMT): In miles per year, by vehicle ownership and classification.
3) Miles-per-Gallon (MPG) on conventional fuel: For gasoline or diesel, by vehicle classification.

4) Thousands of Btu (KBtu) per native unit of fuel: By neat (i.e., pure) replacement fuel. The native units used are: gallons (M85, M100, E85, E95, LPG, and LNG), therms (CNG), and $\mathrm{kWh}$ (electricity).

The following is a description of the seven-step approach used in estimating total annual fuel consumption.

\section{Alternative Fueled Vehicles Categorization}

Alternative fueled vehicles in a given year were categorized according to vehicle classification (auto, light-duty truck, heavy-duty truck, school bus, and transit bus), fuel (M85, M100, E85, E95, LPG, CNG, LNG, and electricity), and ownership (privately owned and government). For example, Table B1 shows the 1995 distribution by vehicle fuel, ownership, and classification for methanol-fueled vehicles.

2. Vehicle-Miles-Traveled by Alternative Fueled Vehicle Classification and Fleet Type

The annual VMT values known from conventional fleets were assigned to each vehicle classification. Light-duty vehicles (LDV's) were segmented

Table B1. Alternative Fueled Vehicles Distribution by Vehicle, Fuel, Ownership, and Classification, 1995 (Methanol-fueled Vehicles Only)

\begin{tabular}{c|r|r|r|c|c|c}
\hline & & \multicolumn{5}{|c}{$\begin{array}{c}\text { Vehicle Classification } \\
\text { (Percentage from Total) }\end{array}$} \\
\cline { 4 - 7 } $\begin{array}{c}\text { AFV Fuel } \\
\text { and } \\
\text { Ownership }\end{array}$ & \multirow{2}{*}{$\begin{array}{c}\text { Number } \\
\text { of Units }\end{array}$} & Auto & $\begin{array}{c}\text { Light-Duty } \\
\text { Truck }\end{array}$ & $\begin{array}{c}\text { Heavy-Duty } \\
\text { Truck }\end{array}$ & $\begin{array}{c}\text { School } \\
\text { Bus }\end{array}$ & Transit Bus \\
\cline { 3 - 8 } & 7,647 & $100.00 \%$ & $0.00 \%$ & $0.00 \%$ & $0.00 \%$ & $0.00 \%$ \\
M85 Private . . . . & 2,829 & $96.11 \%$ & $0.04 \%$ & $0.04 \%$ & $3.82 \%$ & $0.00 \%$ \\
M85 Government . & 1 & $0.00 \%$ & $0.00 \%$ & $100.00 \%$ & $0.00 \%$ & $0.00 \%$ \\
M100 Private .... & 412 & $0.00 \%$ & $0.00 \%$ & $0.73 \%$ & $10.44 \%$ & $88.83 \%$ \\
\hline
\end{tabular}

Source: Science Applications International Corporation, Emissions model prepared for the Energy Information Administration, (McLean, VA, 1994: Q3). 
further into three broad fleet types: rental and service vehicles, private passenger and car pool vehicles, and government pool vehicles. Heavyduty trucks as defined by the EPACT were segmented into medium-and heavy-duty. The conventional fleet characteristics used in the estimation process are listed in Table B2.

\section{Adjustments to Alternative Fueled Vehicle Annual Vehicle Miles Traveled}

The annual VMT values of conventional vehicles shown on Table B2 were revised downward to reflect the less intensive use of AFV's compared to conventional vehicles. Average VMT is lower for AFV's than for conventional vehicles due to differences in vehicle classification and issues of choice. ${ }^{3}$ Conventional light-duty fleet vehicles are typically rental cars and high-usage service vehicles, whereas AFV light-duty fleet vehicles are typically government pool vehicles and lower-usage service vehicles. Factors that reduce AFV utilization relative to conventional vehicles include:

- More frequent refueling because of lower heat content of alternative fuels
- Range restrictions because of limited fuel availability

- Higher maintenance needs and increased incidence of mechanical failures

- Operator perceptions - when choice is available fleet and vehicle operators may drive conventional vehicles more often than AFV's because of their perceptions of safety, vehicle performance, refueling ease, and familiarity with the fuel, regardless of whether these perceptions are correct.

\section{Alternative Fuel Consumption Adjustments}

As defined in EPACT, alternative fuels may be in either a neat form (e.g., pure CNG, LNG, LPG, M100, or electricity), or in a blend (e.g., M85, E85, E95). In the latter case, consumption of ATF's takes into account both the replacement (e.g., net alcohol) and conventional fuel components.

For several AFV types, the effective total fuel cycle of alternative transportation fuel (ATF) consumption per mile travel is higher than commonly thought. Consumption of ATF's is almost always estimated by assuming that Btu-equivalent amounts of ATF

Table B2. Typical Conventional Vehicle Characteristics

\begin{tabular}{|c|c|c|c|}
\hline Vehicle Classification/Fleet Type & $\begin{array}{c}\text { Vehicle Weight } \\
\text { (Ibs) } \\
\end{array}$ & $\begin{array}{c}\text { Annual Vehicle- } \\
\text { Miles-Traveled } \\
\text { (VMT) }\end{array}$ & $\begin{array}{c}\text { Miles-per-Gallon } \\
\text { (MPG) }\end{array}$ \\
\hline $\begin{array}{l}\text { Automobile/ } \\
\text { Private rental and service }\end{array}$ & $0-8,500$ & 24,600 & 24 \\
\hline $\begin{array}{l}\text { Automobile/ } \\
\text { Passenger vehicles and car pools }\end{array}$ & $0-8,500$ & 12,000 & 24 \\
\hline $\begin{array}{l}\text { Automobile/ } \\
\text { Government pool }\end{array}$ & $0-8,500$ & 8,000 & 24 \\
\hline Light-Duty Truck $\ldots \ldots \ldots \ldots$ & $0-8,500$ & 16,400 & 16 \\
\hline Medium-Duty Truck $\ldots \ldots \ldots$ & $8,501-14,000$ & 16,400 & 8 \\
\hline Heavy-Duty Truck . . . . . . . . . . & $14,001-26,000$ & 16,400 & 6 \\
\hline School Bus $\ldots .$. & All & 8,000 & 8 \\
\hline Transit Bus $\ldots \ldots \ldots \ldots \ldots$ & All & 33,200 & 4 \\
\hline
\end{tabular}

Source: Science Applications international Corporation, "Alternative Transportation Fuels and Vehicles Data Development," unpublished final report prepared for the Energy Information Administration, (McLean, VA, August 1994). 
and traditional fuel produce the same VMT. ${ }^{4}$ This assumption is slightly incorrect because of venting of fuel vapor during refueling and maintenance, leakage of gaseous fuels from fuel lines and storage cylinders, engine efficiency differences, and vehicle weight differences. Although natural gas utilities, transit bus facilities, fleet owners, and related industry members are not generally able to isolate and quantify these factors, the net effect is lower miles per Btu for most AFV's than for conventional vehicles.

The efficiencies in MPG of gasoline were determined for all vehicle categories. These values were adjusted to account for higher effective fuel consumption for LNG-, CNG-, and electricity-fueled vehicles. For these AFV's, the miles per Btu ratio was lowered by decreasing the nominal heating values per native unit of fuel. The original and resulting adjusted energy contents per native unit of fuel are shown on Table B3.

5. Vehicle Miles Traveled and Fuel Consumption Adjustments for Dual-, Bi-, and Flexible-Fueled Vehicles

Dedicated vehicles were assumed to be fueled exclusively by replacement fuels (i.e., neat fuel), so that no adjustment was necessary. However, dual-, bi-, and flex-fueled AFV's consume proportions of replacement and traditional fuels that may be significantly different from the nominal proportions in blended fuels. That is, multi-fueled vehicles using M85, for example, do not necessarily consume 85 percent methanol and 15 percent gasoline. To obtain the net amount of alternative fuel used by dual-, bi-, and flexible-fueled vehicles, their VMT values were divided by their adjusted consumption proportions of alternative versus traditional fuels. These proportions are a function of the following:

- Replacement fuel availability - the percentage of traditional fuel used because no replacement fuel is available at the time of refueling.

- Operator's fuel choice - the percentage use of replacement fuel that results from the vehicle operator's fuel choice when available. Choice is affected by perceptions of safety, vehicle performance, refueling ease, and familiarity with the fuel.

These adjustments can be expressed as follows:

VMT on $100 \%$ Alternative Fuel $=$ (fuel availability) $x$ (fuel choice)

6. Conversion to Replacement and Alternative Fuel Consumption in Native Units

The net adjusted annual VMT for 100 percent

Table B3. Original and Adjusted Lower Heating Values of Conventional and Replacement Fuels (Thousand Btu's per native unit of fuel)

\begin{tabular}{|c|c|c|c|}
\hline Fuel Type & $\begin{array}{l}\text { Original Heating Value } \\
\text { per Native Unit of Fuel }{ }^{1} \\
\text { (Thousand Btu) }\end{array}$ & $\begin{array}{l}\text { Added Fuel } \\
\text { Loss } \\
\text { (Percent) }\end{array}$ & $\begin{array}{l}\text { Adjusted Heating Value } \\
\text { per Native Unit of Fuel } \\
\text { (Thousand Btu) }\end{array}$ \\
\hline Methanol & $57.00 /$ Gallon & 0.01 & $57.00 /$ Gallon \\
\hline$\ldots \ldots \ldots$ & 76.00 /Gallon & 0.01 & 76.00 /Gallon \\
\hline$\ldots \ldots \ldots \ldots$ & $84.00 /$ Gallon & 0.00 & 84.00 /Gallon \\
\hline CNG & 93.00 /Therm & 0.50 & 92.54 Therm \\
\hline Electricity & $3.41 / \mathrm{kWh}$ & 2.00 & $3.34 / \mathrm{kWh}$ \\
\hline LNG . . . . . . . . & $68.00 /$ Gallon & 2.00 & 66.64 /Gallon \\
\hline Diesel & 128.00 /Gallon & 0.00 & 128.00 /Gallon \\
\hline Gasoline . . . . . . . . & 115.00 /Gallon & 0.00 & 115.00 /Gallon \\
\hline
\end{tabular}

'Lower heating value.

Source: Science Applications International Corporation, Emissions Model prepared for the Energy Information Administration, (McLean, VA, updated 1994:Q3). 
alternative fuel use were then divided by miles per unit of alternative fuel. The result was alternative fuel consumption by AFV's.

\section{Conversion to Gasoline-Equivalent Gallons}

Gasoline-equivalent gallons was computed by dividing the lower heating value of the alternative fuel by the lower heating value of gasoline and multiplying this result by the alternative fuel consumption value (from step 6).

\section{Oxygenate Consumption}

The consumption of ethanol and MTBE in 1992 and 1993 was estimated from production, net imports, and stock change data obtained from the Form EIA819M, "Monthly Oxygenate Telephone Report," published in the Petroleum Supply Monthly (DOE/EIA-0109). Consumption is calculated as production plus net imports less stock change. For 1995, consumption is from the Short Term Energy Outlook, 3rd Quarter 1994, (DOE/EIA-0202 (94/3Q)).

\section{Notes}

'Estimates of LPG consumed for transportation use from the Energy Information Administration, State Energy Data Report 1992, DOE/EIA0124(92) (Washington, DC, May 1994), Table 10.

${ }^{2}$ Science Applications International Corporation in-house survey of CNG-fueled vehicle counts and refueling facilities.

${ }^{3}$ Science Applications International Corporation, "Alternative Transportation Fuels and Vehicles Data Development" unpublished final report prepared for the Energy Information Administration, (McLean, VA, August 1994).

'A notable exception is in Argonne National Laboratory, Center for Transportation Research, Emissions of Greenhouse Gases from the Use of Transportation Fuels and Electricity, ANL/ESD/TM-22, prepared by Dr. Mark DeLuchi, Vol 1 (Argonne, IL, November 1991) and Vol 2 (Argonne IL, November 1993), which provides miles per Btu adjustment factors for AFV's. 


\section{The Greenhouse Effect}

The "greenhouse effect" involves the amount and characteristics of the sun's radiation, which is absorbed by the earth and reflected back into the atmosphere. (The sun's short-wave radiation is absorbed by the earth and radiated back into the atmosphere as long-wave infrared radiation.) Greenhouse gases in the earth's atmosphere absorb much of the infrared waves and re-radiate some of the reflected energy back to the earth. This heattrapping characteristic of greenhouse gases keeps the average temperature of the earth today at about 59 degrees Fahrenheit. ${ }^{1}$ The concern is that as the concentration of greenhouse gases increases, the amount of energy absorbed and re-radiated back to earth will also increase, raising the average temperature of the atmosphere around the earth and raising sea levels. A rise in temperature (i.e., global warming) would potentially change global climate patterns.

The principal greenhouse gases are water vapor $\left(\mathrm{H}_{2} \mathrm{O}\right)$, carbon dioxide $\left(\mathrm{CO}_{2}\right)$, methane $\left(\mathrm{CH}_{4}\right)$, nitrous oxide $\left(\mathrm{N}_{2} \mathrm{O}\right)$, chlorofluorocarbons (CFC's) and ozone $\left(\mathrm{O}_{3}\right)$. Automotive CFC's, which are used in vehicle air conditioners, are scheduled to be phased out, are not relevant when considering fuel type, and therefore are not considered in this report.

The earth's atmosphere is warmed by three primary pathways: solar insolation, geothermal energy radiating from the earth's core, and energy releases by living creatures, of which fuel consumption is the main component. While geothermal and solar radiation warm the air across all latitudes, fuel combustion warms the air in regional patterns.

Different greenhouse gases have different impacts on the earth's warming. Their warming abilities vary because of differences such as:

- Relative atmospheric concentration levels.

- Relative changes in atmospheric concentration over time.

- Their ability to absorb and radiate energy; and

- The amount of time they exist in the atmosphere (lifetimes).

Atmospheric water vapor is the most abundant greenhouse gas. Its concentrations are dominated by natural sources and sinks such as evaporation from oceans and precipitation. ${ }^{2}$ Increased water vapor exacerbates heat retention, but assists in decreasing atmospheric $\mathrm{CH}_{4}$ and $\mathrm{CO}$. Water vapor is not considered in many studies of greenhouse gas emissions because water vapor from burning of fossil fuels is considered negligible relative to total water vapor in the atmosphere. However, increased water vapor concentrations in urban and metropoli$\tan$ areas increases their ozone production in a nonnegligible manner.

Carbon dioxide is the next most abundant greenhouse gas and is increasing in the atmosphere at a rate of about 0.5 percent per year. ${ }^{3}$ Carbon dioxide in the atmosphere increases with deforestation and combustion of fossil fuels, but is reduced through $\mathrm{CO}_{2}$ transfers to sinks such as oceans and vegetation. One study estimated that about 45 percent (the estimate has a 10-percent margin of error) of the $\mathrm{CO}_{2}$ emissions accumulate in the atmosphere, and that the slower the emissions increase, the smaller the fraction that remains in the atmosphere. ${ }^{4}$ Increased $\mathrm{CO}_{2}$ may act as a fertilizer, increasing the growth of vegetation and thereby indirectly increasing the $\mathrm{CH}_{4}$ production.

Methane atmospheric concentration is much lower than that of $\mathrm{CO}_{2}$, but has been increasing during recent years. Methane molecules absorb more infrared radiation than $\mathrm{CO}_{2}$ molecules, but have a much shorter atmospheric lifetime (on average about 10 years). Natural sources of $\mathrm{CH}_{4}$ include enteric formation in animals (including insects) and anaerobic decomposition in both woodlands and wetlands. Anthropogenic sources include enteric fermentation in cattle, releases from rice paddies, biomass burning, and leakage from natural gas, coal and oil cycles, and from solid waste in landfills. One of the most important sinks is the photochemical oxidation of $\mathrm{CH}_{4}$ by tropospheric hydroxyl ions $\left(\mathrm{OH}^{-}\right)$radicals. Carbon monoxide also reacts with $\mathrm{OH}^{-}$radicals, competing with $\mathrm{CH}_{4}$. The rate of removal of $\mathrm{CH}_{4}$ by this mechanism has changed because of increasing emissions of $\mathrm{CO}$ from fossil fuel combustion and from forests' burning.

Like $\mathrm{CH}_{4}$ and $\mathrm{CO}_{2}, \mathrm{~N}_{2} \mathrm{O}$ concentration is increasing. Nitrous oxide is present in the atmosphere in only minute quantities, but it absorbs more infrared 
energy than either $\mathrm{CH}_{4}$ or $\mathrm{CO}_{2}$, and it has a long average residence time in the atmosphere of over 100 years. Global emissions of $\mathrm{N}_{2} \mathrm{O}$ are small relative to emissions of $\mathrm{CO}_{2}$ or $\mathrm{CH}_{4}$. The main natural sources of $\mathrm{N}_{2} \mathrm{O}$ in the atmosphere are from microbial processes in oceans, estuaries and soils. The major anthropogenic sources are fossil fuel combustion, fertilized soils, biomass burning, and cultivated natural soils. The main sink is photolysis in the stratosphere. ${ }^{5}$

Ozone is not emitted, but is both produced and destroyed in the atmosphere. Ozone that is produced in the troposphere (lower atmosphere) acts as a greenhouse gas, absorbing the sun's reflected energy and radiating infrared wavelength energy. (Ozone in the troposphere can also cause respiratory problems.) Concentrations of $\mathrm{O}_{3}$ in the troposphere are a result of complex chemical reactions involving heat, $\mathrm{CO}, \mathrm{NO}_{\mathrm{x}}$ nonmethane organic compounds (NMOC's), $\mathrm{OH}^{-}$(from water vapor), and other compounds. Carbon monoxide, $\mathrm{NO}_{x}$ and NMOC's are frequently included in greenhouse effect discussions because of their role in $\mathrm{O}_{3}$ formation in the troposphere. About 90 percent of atmospheric ozone is found in the stratosphere (upper atmosphere), where it absorbs ultraviolet radiation that would otherwise reach the earth's surface. This radiation can cause health problems, such as increased incidents of cancer and cataracts.

The concentrations of greenhouse gases in the atmosphere have been growing. This is a result of both growth in the production of the gases as well as a reduction in the sinks or reservoirs for some gases. Reduction in greenhouse gas sinks such as deforestation is an important concern for global warming. This report focuses on transportation fuel cycle sources, but the greenhouse gas impact is the net effect of both sources and sinks. Biomass fuels provide one example where consideration of sinks plays an important role in transportation fuel impacts. The change in the $\mathrm{CO}_{2}$ sink that results from changes in land use due to biomass production affects the net $\mathrm{CO}_{2}$ production from use of biofuels. If forest land is cleared to grow a fuel crop that does not sequester as much $\mathrm{CO}_{2}$ as the prior forest, a net increase in $\mathrm{CO}_{2}$ emissions will occur; however, if crop land is being replaced by short-rotation, intense cultivation trees, a net reduction in $\mathrm{CO}_{2}$ would occur (Appendix E).

Because of the different earth-warming capabilities among the greenhouse gases, many studies convert the emissions of these gases into " $\mathrm{CO}_{2}$-equivalent" emissions. Such equivalency factors provide a means of combining the gases in order to compare one fuel type against another. The information needed to develop the conversion factors, however, is not well established.

\section{Greenhouse Gas Equivalency Factors}

Providing fuels for transportation needs has a wide variety of social, economic and environmental impacts. While the Clean Air Act Amendments of 1990 addressed some of the hazardous health emissions from vehicles, the Energy Policy Act of 1992 began to address the greenhouse effect of producing and using transportation fuels. For policy purposes, one would like to know the costs and the benefits of each fuel presented in a manner that would allow comparisons among the fuels. The direct cost side of the presentation is relatively straightforward. The impacts of emissions (particularly the indirect costs) are not. Today, there are no good means for combining and weighing health impacts, greenhouse gas impacts, and other impacts into a single index. The problem is being approached one impact at a time.

The greenhouse effect alone has a similar dilemma. The greenhouse effect is influenced by many different greenhouse gases. The different gases have different potentials to warm the earth's surface because of factors such as differences in their ability to absorb and re-radiate energy, in their resident lifetimes in the atmosphere, and in their relative and absolute concentrations in the atmosphere. In order to compare one fuel's total greenhouse impact to another, a method must be used to estimate the impacts of all the greenhouse gases emitted from one fuel cycle to another. This requires converting the emissions into a common "warming potential." So far, studies have estimated the warming potential in terms of a $\mathrm{CO}_{2}$-equivalent warming potential.

For example, the DeLuchi and EPA studies use a factor that indicates that over a 100-year time horizon, $\mathrm{CH}_{4}$ emitted today has a "temperatureequivalent mass" 21 times that of $\mathrm{CO}_{2}$. That is, it would take 21 times the amount of $\mathrm{CO}_{2}$ (in grams) to produce the same warming effect as $1 \mathrm{gram}$ of $\mathrm{CH}_{4}$ over the next 100 years. Factors for all gases have varying degrees of acceptance and uncertainty.

Although no indexing approach captures all of the relevant factors for global warming, the index approach used by DeLuchi was developed by the 
Intergovernmental Panel on Climate Change (IPCC) in 1990, and is the approach that has gained some acceptance. It is referred to as the "global warming potential" approach. The global warming potential (GWP) is a function of a radiative forcing term (warming potential), time, and the concentration of the gas as a function of time:

$$
G W P_{i}=\frac{\int_{0}^{T} a_{i}(t) c_{i}(t) d t}{\int_{0}^{T} a_{C O_{2}}(t) c_{C O_{2}}(t) d t}
$$

$\begin{aligned} \mathrm{GWP}_{1}= & \begin{array}{l}\text { Global warming potential } \\ \text { for gas (i) }\end{array} \\ \mathbf{t}= & \begin{array}{l}\text { The time horizon over } \\ \text { which the emissions are } \\ \text { being considered (e.g., 20, } \\ 100, \text { or } 500 \text { years) }\end{array}\end{aligned}$

$a_{1}(t)=\quad$ Relative radiative forcing of gas (i) as a function of time

$c_{i}(t)=$ Amount of gas (i) remaining in the atmosphere at time $t$

$$
\begin{array}{lll}
\mathrm{dt} & = & \text { Change in time } \\
\mathrm{t} & = & 20,50, \text { or } 100 \text { years }
\end{array}
$$

Estimating the radiative forcing and concentration functions is complex and simplifications are generally made.

\section{Radiative Forcing}

Pure gases have different abilities to absorb and reradiate energy. Equivalency estimates usually assume constant values for the relative radiative forcing factors $\left(a_{1}\right)$. In general, this is not true. In the atmosphere, a particular gas's ability to absorb the earth's reflected energy is also a function of its concentration and the concentration of other gases because of the overlap in absorption bands among the gases. Two gases that absorb energy of the same frequency, such as $\mathrm{CH}_{4}$ and $\mathrm{N}_{2} \mathrm{O}$, may not have as much incremental effect on warming at higher concentrations in the future than at current concentrations, since they are both filling the same thermal emission window. Even estimating the current radiative forcing of the greenhouse gases is uncertain. For example, many studies assume that $\mathrm{CH}_{4}$ absorbs about 20 times the energy of $\mathrm{CO}_{2}$. However, one analysis indicated that $\mathrm{CH}_{4}$ may be only 13.2 times as effective as $\mathrm{CO}_{2}$ which is a considerable difference. $^{6}$

\section{Lifetimes}

Equivalency estimates generally use a single residency time or lifetime for each greenhouse gas. The equivalency depends on the assumed lifetime of $\mathrm{CO}_{2}$, which is one of the most difficult variables to estimate because it is not destroyed by chemical processes, but flows in cycles between the atmosphere and reservoirs such as the ocean. Modeling of the $\mathrm{CO}_{2}$ cycle can be used to estimate the average $\mathrm{CO}_{2}$ lifetimes using a weighted average residence time. Different studies can use different lifetimes for $\mathrm{CO}_{2}$, creating different equivalency factors.

Other greenhouse gases are removed by chemical and physical processes and never return. The average lifetime can be defined as the ratio of the total atmospheric content to the removal rate in grams per year. This results in a point estimate for the lifetime. In reality, concentrations, and thus lifetimes, of gases change as concentrations of other gases change. For example, $\mathrm{CH}_{4}$ and $\mathrm{CO}$ both are removed by reacting with $\mathrm{OH}$. If the production of $\mathrm{OH}^{-}$stays constant, but the concentrations of $\mathrm{CH}_{4}$ and $\mathrm{CO}$ increase, the lifetime of $\mathrm{CH}_{4}$ increases. Thus estimates of the $\mathrm{CH}_{4}$ lifetime should be a function of $\mathrm{CH}_{4}, \mathrm{CO}$, and $\mathrm{OH}^{-}$concentrations over time.

\section{Time Consideration}

All equivalency analyses have an underlying time consideration. Is the warming effect of a gas emitted today "worth" the same warming effect 100 years from now when it is still radiating? It is not clear if one should discount the future warming or inflate the impact. The atmospheric lifetimes of many of these gases are longer than a human lifetime. Most equivalency factors do not try to discount the emissions.

The second time factor that influences equivalency factors is the length of time used for aggregating emissions. Due to the different lifetimes of the gases, a shorter time period will generally produce a larger equivalency factor since most greenhouse gases have larger radiative forcing per $\mathrm{mole}^{7}$ and a shorter atmospheric lifetime than $\mathrm{CO}_{2}$. 
Global warming potentials are being reevaluated for the new international climate and ozone assessments by the IPCC. Table $\mathrm{C} 1$ shows some preliminary GWP's for selected greenhouse gases. They are provided for three time periods (integral interval): 20,100 and 500 years. The values for these GWP's have been updated several times and will continue to change as more research is accomplished. Analysts must not only appreciate the uncertainties surrounding the estimations of global warming potential indices, but also which global warming indices were used by particular studies.

Table C1. Direct Global Warming Potentials

$$
\text { (Index, } \mathrm{CO}_{2}=1 \text { ) }
$$

\begin{tabular}{|c|c|c|c|}
\hline \multirow[b]{2}{*}{ Gas } & \multicolumn{3}{|c|}{ Time Horizon } \\
\hline & 20 Years & 100 Years & 500 Years \\
\hline $\mathrm{CO}_{2}$ & 1 & 1 & 1 \\
\hline $\mathrm{CH}_{4}$ & $56-110$ & $19-43$ & $9-16$ \\
\hline $\mathrm{N}_{2} \mathrm{O}$ & 290 & 320 & 170 \\
\hline
\end{tabular}

Note: Greenhouse gases are defined in the Glossary. $\mathrm{CO}_{2}=$ Carbon Dioxide; $\mathrm{CH}_{4}=$ Methane, $\mathrm{N}_{2} \mathrm{O}=$ Nitrous Oxide.

Source: U.S. Department of Energy, Sector-Specific Issues and Reporting Methodologies Supporting the General Guidelines for the Voluntary Reporting of Greenhouse Gases under Section 1605(b) of the Energy Policy Act of 1992, Global Warming Potentials, Part 7 of 7 Supporting Documents, Public Review Draft, DOE/PO-0015, (Washington, DC: May 31, 1994), pp 7.5-7.6.

\section{Notes}

${ }^{1}$ Energy Information Administration, Emissions of Greenhouse Gases in the United States, 1985 - 1990, DOE/EIA-0573 (Washington, DC: October, 1993), p.1.

${ }^{2}$ Energy Information Administration, Emissions of Greenhouse Gases in the United States, 1985-1990, DOE/EIA-0573 (Washington DC, October, 1993), p.8.

${ }^{3}$ Organization for Economic Cooperation and Development, International Energy Agency, Greenhouse Gas Emissions, The Energy Dimension (1991), p. 15.

${ }^{4}$ Organization for Economic Cooperation and Development, International Energy Agency, Greenhouse Gas Emissions, The Energy Dimension (1991), p. 16, citing B. Bolin, "How much $\mathrm{CO}_{2}$ will remain in the atmosphere?" The Greenhouse Effect, Climatic Change and Ecosystems, (Chichester: J. Wiley and Sons).

${ }^{5}$ Organization for Economic Cooperation and Development, International Energy Agency, Greenhouse Gas Emissions, The Energy Dimension (1991), p.18.

'Argonne National Laboratory, Emissions of Greenhouse Gases from the Use of Transportation Fuels and Electricity, Vol 2, pp. O-7, citing R.R. Gamache and D. Golumb, The Relative Role of Methane and Carbon Dioxide in the Greenhouse Effect. (Arlington, VA, January 1990).

${ }^{7}$ One mole of an element or compound contains about $6.023 \times 10^{23}$ molecules and weighs the sum of the molecules atomic weights in grams. 


\section{Fuel Cycle and Energy Efficiency Considerations}

\section{The Fuel Cycle Analysis Process}

Greenhouse gas emissions from transportation fuels originate from every point in a fuel cycle in which energy is consumed and at which emissions are produced (Figure D1): from resource extraction, from conversion to an engine fuel, from resource or fuel transportation, and from vehicle fuel evaporation and combustion. In addition, biomass fuels (i.e., fuels derived from biomass) in some cases can be credited with removing $\mathrm{CO}_{2}$ from the atmosphere when the biomass is being grown (Appendix $\mathrm{E}$ ).

Defining and estimating comparable emissions across the different fuel cycles are complex. Analyzing emissions from fuel cycles requires the following steps.

\section{Determining the Time Period for Analysis}

Analysts are frequently interested in comparing energy and emission impacts at some future date when alternative fuels will have evolved into largerscale commercial ventures. This not only requires establishing the data that are available today for efficiencies and emissions, but also making assumptions about improvements over time. Some information, such as vehicle efficiencies, is not well known, and theoretical values may be used until actual data are obtained.

\section{Defining the Fuel Cycle}

A transportation fuel cycle begins with resource recovery and ends with vehicle fuel consumption. Fuel cycles are usually divided into resource recovery, transportation of the resource to processing facilities, processing, delivery of the product to vehicle fueling facilities, and, finally, vehicle combustion. Some fuel cycle studies consider the impacts on energy and emissions from the manufacture of the capital stock contained in the fuel cycle (e.g., production equipment and vehicles). These considerations require estimates of the fuels and associated emissions used in producing the facilities and machinery, and an estimate of the lifetime of the equipment in order to allocate the capital stock emissions over time.

\section{Determining the Energy Efficiencies at Each Stage of the Fuel Cycle}

Generally, greenhouse gases are emitted as fuels evaporate (through leakage) or are burned. Thus the bases of the emissions' estimations are the fuel types used at each stage and the fuel quantities employed. The relationship between energy inputs and outputs at each fuel cycle stage (energy balance) is important for determining total fuel cycle emissions. (Biomass fuels have additional characteristics that are described in Appendix E.)

\section{Calculating Emissions of Each Greenhouse Gas at Each of the Major Fuel Cycle Stages}

To determine the greenhouse gas emissions for each stage of the fuel cycle, information on the specific fuels being used, fuel composition (e.g., carbon content), technologies such catalytic converters on vehicles, and combustion characteristics must generally be known. ${ }^{1}$ This information is synthesized into emission factors that represent the quantity of emissions per unit of fuel consumed. Multiplying emission factors by fuel consumption yields the emission quantities used for estimating total greenhouse gas emissions. The fuel cycle analysis process is demonstrated below using the gasoline cycle (which is the baseline against which alternative fuels are compared) as an example.

The resource base for today's gasoline is mainly crude oil. Extracting crude oil requires energy. Since crude oil and natural gas are sometimes coproduced, the energy used in extraction must be allocated between the two resources. Energy for extraction includes crude oil, diesel, residual oil, natural gas, electricity, gasoline and some other energy sources such as coal. Diesel, for example, is used for development drilling, electricity is used for pumps, and lease gas is used to reinject associated gas used for repressurization of oil wells. Different fuels in different amounts are used for onshore wells versus offshore wells. Therefore, some assumptions must be made about the amount of crude oil coming from onshore versus offshore. Finally, assumptions on energy use for crude production from foreign sources versus domestic are needed. 


\section{Entire Fuel Cycle for Transportation Fuels}

The Physical Flow Diagram for Mobile Source Emissions (Figure D1) traces the entire fuel cycle for transportation fuels. Nodes represent points at which distinct processes occur; arrows represent the physical flow of the fuel or fuel feedstock, through the fuel cycle from resource production to transportation. The nodes are characterized into distinct fuel cycle stages:

Resource Recovery (e.g.,mining, drilling, agricultural production)

Process (e.g., refining, enrichment)

Product (e.g., production of electricity, gasoline, methanol)

Vehicle loperation of conventional and alternative fueled vehicles)

The flow chart diagram is a convenient way to represent the fuel cycle because many of the fuels can be derived from multiple feedstocks and processes.

Once crude oil is produced, it must be transported to refineries. Crude oil may be transported by tankers, pipelines, trucks and rail. Estimates can be made about the fuels used in the different modes (e.g., electricity for pipelines), efficiencies of the various modes of transportation (e.g., in Btu/Tonmiles), and how much crude travels by the different modes. For example, foreign crude travels greater distances by tanker than domestic crude. Once foreign crude reaches the U.S. coast, it frequently will be processed by a refinery close to the port. Domestic crude, on the other hand, is usually transported by pipeline from the production fields to the refineries.

When the crude oil reaches the refineries, a new set of fuel use and fuel allocation problems must be resolved. Different fuels are used throughout the refinery to produce a slate of products from gasoline and diesel to petroleum coke and residual fuel oil. A method must be used to estimate the types and quantities of different fuels used in processing the petroleum products and to allocate the energy consumed in the refinery to the different products.

Next, the gasoline is moved by various modes of transportation to retail outlets for vehicle use. Again, estimations must be made regarding the means of transportation, the distances traveled, the fuels used and associated efficiencies.
Finally, vehicle efficiencies (miles per gallon) must be considered. For a single fuel such as gasoline, fuel consumption efficiencies vary due to different engine thermal efficiencies and different vehicle weights. For greenhouse gas fuel cycle studies, a single gasoline vehicle efficiency for light-duty vehicles is generally used. It can be an average efficiency or the efficiency of a future vehicle depending on the purpose of the study. The greenhouse gas emissions arising from gasoline combustion (or from any fuel combustion) are a function of the fuel consumption rate, the carbon content of the fuel, and the combustion properties of the fuel/engine system.

When the fuel cycle analysis is expanded to other fuels, vehicle efficiencies and associated greenhouse gas emissions are developed for various alternative fueled vehicle types such as light-duty, heavy-duty, dedicated, flexible-fueled, dual-fueled, and bi-fueled vehicles. Just as with the gasoline-fueled vehicles, these vehicle types have individual fuel type characteristics, different thermal efficiencies and different weights - all of which affect greenhouse gas emissions.

All along the fuel cycle, fuels can leak and produce emissions. Fuel lost this way decreases the efficiency of the cycle and contributes directly to greenhouse gases. For gasoline, evaporative losses are a function of the volatility of the fuel, molecular 
weight of the vapor, and evaporative controls being used. These efficiency and emission impacts must also be taken into consideration for a full fuel cycle analysis.

\section{Energy Efficiency}

Energy efficiencies are stated in million Btu's of energy of product out of the fuel cycle stage divided by million Btu's of energy that went into the stage, including the energy content of the fuel feedstock and process energy such as electricity for lighting, diesel for pumps, and fuel for transportation modes. Thus, the lower this energy output/energy input ratio, the less efficient the stage. The DeLuchi Report illustrates some of the complexities of estimating energy efficiencies and identifying the subset of the greenhouse gases which result from each fuel. In general, the DeLuchi Report uses detailed estimates of the types and amounts of fuels used at each of the fuel cycle stages. Changes in these factors alone can lead to different efficiencies and different greenhouse gas emission estimates. ${ }^{2}$ Table D1 shows energy efficiencies (total result of all fuels used in a given stage) estimated by DeLuchi for each of the stages for several fuel cycles. It also includes energy losses due to manufacturing of vehicles. The processing/conversion stage is usually the least efficient stage (i.e., lowest energy output/energy input ratio). For example, this study shows an energy efficiency of 0.67 for conversion of natural gas to methanol. That is, 1.5 million Btu's of feed and fuel energy are input at this stage for every 1.0 million Btu's of methanol produced. Efficiency for corn to ethanol conversion is assumed to be 0.63 , representing a future plant that might be even more efficient than today's best plants. ${ }^{3}$

There are some important methodological issues regarding energy efficiency. In analyzing the impacts from switching from traditional to replacement transportation fuels, one can investigate the incremental impacts or average impacts. The incremental approach analyzes the impact of replacing the last gallon of gasoline produced with a new gallon of replacement fuel. This type of analysis might view the replacement fuel as coming from the next newest production facility. The efficiency estimate for this gallon of ethanol would thus come from a "best case" new-plant situation. The gallon of gasoline being replaced is the last gallon produced by a fully utilized (and potentially least efficient) refinery. The incremental energy required to produce this incremental gallon of gasoline is higher than the average energy needed to produce all of the gallons of gasoline from the refinery.

The DeLuchi Report combines both an incremental analysis and several average energy analyses to estimate the gasoline conversion efficiency (Table D1). Since the incremental production of a gallon of gasoline takes more energy than the production of

Table D1. Energy Efficiency for Stages in Providing Transportation Fuels to Consumers (Million Btu's Energy Output/Million Btu's Energy Input)

\begin{tabular}{|c|c|c|c|c|c|}
\hline Fuel Cycle Stage & $\begin{array}{l}\text { Unleaded } \\
\text { Gasoline }\end{array}$ & $\begin{array}{l}\text { Compressed } \\
\text { Natural Gas }\end{array}$ & $\begin{array}{c}\text { Methanol } \\
\text { from } \\
\text { Natural Gas }\end{array}$ & $\begin{array}{c}\text { Ethanol from } \\
\text { Corn }\end{array}$ & $\begin{array}{l}\text { LPG from } \\
\text { Oil \& Gas }\end{array}$ \\
\hline Fertilizer Production & $\overline{N M}$ & NM & NM & 0.838 & $\overline{\mathrm{NM}}$ \\
\hline Resource Production & 0.974 & 0.974 & 0.952 & 0.909 & 0.975 \\
\hline $\begin{array}{l}\text { Feedstock } \\
\text { Transportation . . . . . }\end{array}$ & 0.988 & 1.000 & 0.986 & 0.975 & 0.994 \\
\hline Conversion/Production & 0.873 & 0.977 & 0.665 & 0.633 & 0.958 \\
\hline Product Transportation & 1.000 & 1.000 & 1.000 & 1.000 & 1.000 \\
\hline Product Distribution .. & 0.992 & 0.965 & 0.964 & 0.973 & 0.990 \\
\hline Refueling . . . . . . . & 1.000 & 0.979 & 1.000 & 1.000 & 1.000 \\
\hline Full Fuel Cycle $\ldots \ldots$ & 0.838 & 0.901 & 0.610 & 0.519 & 0.921 \\
\hline
\end{tabular}

$\mathrm{NM}=$ not meaningful.

Source: Derived from greenhouse gas emissions results provided to the Energy Information Administration, July 1994 . Results are from an unpublished revision of: Argonne National Laboratory, Center for Transportation Research, Emissions of Greenhouse Gases from the Use of Transportation Fuels and Electricity, ANL/ESD/TM-22, prepared by Dr. Mark DeLuchi, Vol. 1 (November 1991) and Vol. 2 (November 1993). 
gasoline on average, gasoline conversion efficiency is slightly lower than it otherwise might be.

Since the EIA must estimate the total greenhouse gas impacts of each fuel, an average impact analysis approach is preferred. For example, current ethanol facilities along with new facilities being built would have to be considered in the energy efficiency and associated greenhouse gas impacts. Gasoline greenhouse gas emissions must be estimated for the refinery as a whole using an average energy efficiency.

Another efficiency issue involves electricity. Electricity is generated from different generating unit types that have different efficiencies and use different fuels. The mix of fuel types and generating units varies from utility to utility, and has some distinct regional differences. For example, the Northwest uses a larger percentage of hydropower than the national average, while the Midwest uses a larger mix of coal-fired generating capacity. The DeLuchi Report attempts to tailor electricity efficiencies to the generating facilities supplying the power. Since ethanol production facilities are mainly in the Midwest, the DeLuchi Report uses a regional generating mix appropriate to the Midwest for electricity used in ethanol production. ${ }^{4}$
The full fuel cycle efficiency shown on Table D1 is the final amount of energy delivered at the refueling point divided by all the energy inputs in all of the stages beginning with resource production. That is, a 0.50 full fuel cycle efficiency indicates that 2 million Btu's (including resource feed) is needed to produce 1 million Btu's of fuel for a vehicle. Compressed natural gas and LPG have the highest full fuel cycle efficiencies, which is not surprising since these fuels require no conversion of the primary resource into another fuel form and only need a small amount of processing. Compressed natural gas is slightly less efficient overall than LPG in the DeLuchi Report due to the higher energy requirements in natural gas distribution and the need to compress the fuel. Gasoline ranks third, methanol fourth, and ethanol is the least efficient.

The efficiencies are recast in Table D2 as million Btu's of energy consumed at each fuel cycle stage for every million Btu's of final fuel energy delivered to the vehicles. For example, one million Btu's of methanol delivered to vehicles requires an additional 0.64 million Btu's of energy to produce the fuel delivered.

Once the fuel is delivered to the vehicle, the vehicle efficiency (miles per gallon) is considered. The

Table D2. Energy Consumption for Stages in Providing Transportation Fuels to Consumers (Million Btu's Energy Used/Million Btu's Delivered Product)

\begin{tabular}{|c|c|c|c|c|c|}
\hline Fuel Cycle Stage & $\begin{array}{l}\text { Unleaded } \\
\text { Gasoline }\end{array}$ & $\begin{array}{l}\text { Compressed } \\
\text { Natural Gas }\end{array}$ & $\begin{array}{l}\text { Methanol } \\
\text { from } \\
\text { Natural Gas }\end{array}$ & $\begin{array}{l}\text { Ethanol } \\
\text { from Corn }\end{array}$ & $\begin{array}{l}\text { LPG from } \\
\text { Oil \& Gas }\end{array}$ \\
\hline Fertilizer Production & $\overline{\mathrm{NM}}$ & $\overline{N M}$ & NM & 0.194 & $\overline{N M}$ \\
\hline Resource Production & 0.027 & 0.028 & 0.077 & 0.100 & 0.026 \\
\hline Feedstock Transportation & 0.012 & 0.000 & 0.021 & 0.026 & 0.012 \\
\hline Conversion/Production & 0.146 & 0.025 & 0.504 & 0.580 & 0.044 \\
\hline Product Transportation & 0.000 & 0.000 & 0.000 & 0.000 & 0.000 \\
\hline Product Distribution & 0.008 & 0.036 & 0.038 & 0.028 & 0.010 \\
\hline Refueling $\ldots \ldots \ldots$ & 0.000 & 0.022 & 0.000 & 0.000 & 0.000 \\
\hline Full Fuel Cycle . . . . . & 0.193 & 0.110 & 0.639 & 0.927 & 0.092 \\
\hline
\end{tabular}

NM $=$ not meaningful.

Source: Derived from greenhouse gas emissions results provided to the Energy Information Administration, July 1994. Results are from an unpublished revision of: Argonne National Laboratory, Center for Transportation Research, Emissions of Greenhouse Gases from the Use of Transportation Fuels and Electricity, ANL/ESD/TM-22, prepared by Dr. Mark DeLuchi, Vol. 1 (November 1991) and Vol. 2 (November 1993). 
efficiency improvements assumed are: Vehicles consuming reformulated gasoline, none; dedicated methanol-fueled vehicles, 15 percent; dedicated ethanol-fueled vehicles, 14 percent; CNG-fueled vehicles, 7 percent; and LPG-fueled vehicles, 10 percent. The DeLuchi Report considers both thermal efficiency and weight differences between vehicles.

\section{Notes}

${ }^{1}$ A major emission factor reference for stationary sources is: U.S. Environmental Protection Agency, Office of Air Quality Planning and Standards, Supplement to Compilation of Air Pollutant Emission Factors, Volume 1 (Research Triangle Park, NC, July 1993).

${ }^{2}$ For instance, the EPA study, Alternative Transportation Fuels and the Greenhouse Effect, uses a less detailed representation of fuel use at each stage of the fuel cycle and uses estimates which vary from those used by DeLuchi.

${ }^{3}$ Companies do not always choose the "best" plant from an energy efficiency standpoint. Sometimes the added capital costs cannot be justified by the savings from improved energy efficiency. When new plants are being built, plant design is driven by economics and regulatory constraints. Energy efficiency is pursued when it is economic.

The Midwest uses more coal to generate electricity than the national average. If a national average mix of fuels were used, estimates of greenhouse gas emissions would probably be lower than actual emissions. 


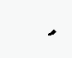




\section{ENTIRE FUEL CYCLE FOR TRANSPORTATION FUELS}

Physical Flow Diagram - Mobile Source Emissions

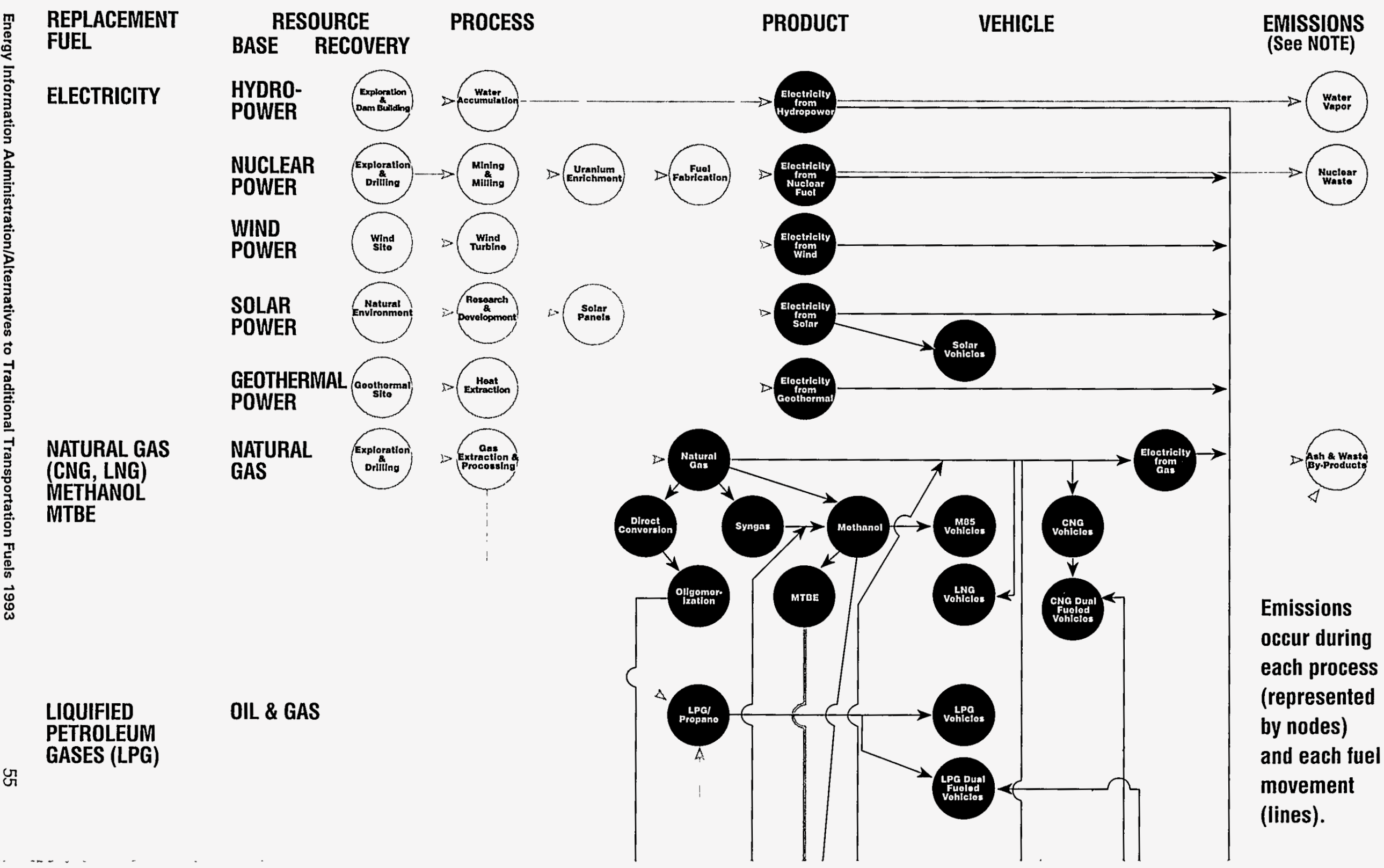




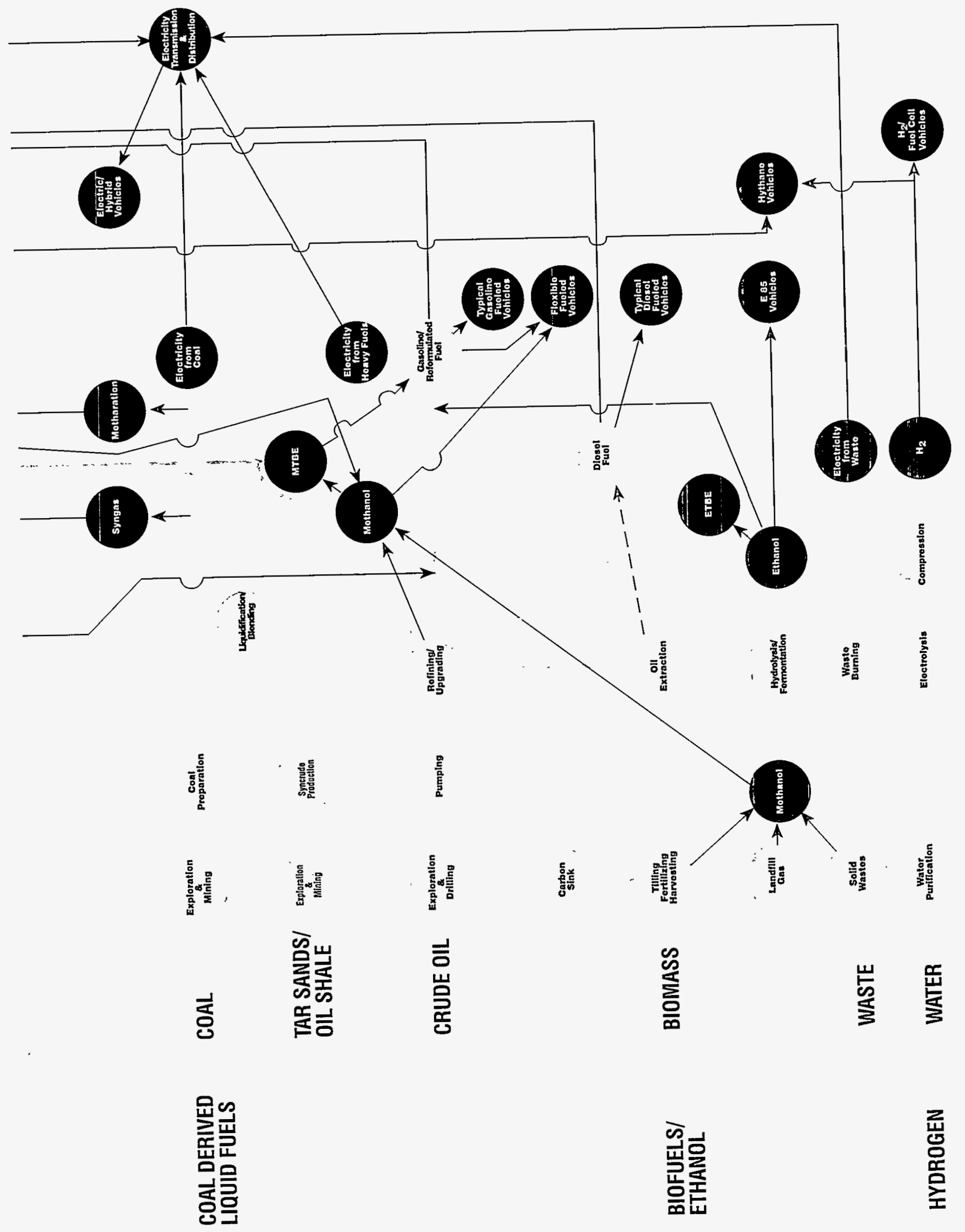


Mobile Source Energy Consumption delling, Use \& Salvage of a Vehicte

10if Distinct By-products with

Distinct By-products with
Emvironmental Consititerations

Energy Consumptian \& Emissions
Due to Beplasement fuel
Produetion Processes
Energy Consumption \& Emissions Due To Transport

Physical Flow of Fuel into

Consummable Forn (Includes Waste By-products) . . . . * .. . Possible Physical Flow of Rape Sources into Comesmable Forms

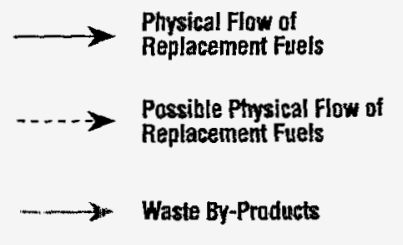

Physical Fiow of Ethers into
Oxygenated/ieformulated Gasolines

Waste By-Praducts

Emissions and waste by-products occur with venting/flaring during resource recovery, direct and indirect production processes, transport of products and refueling of vehicles, as well as during the combustion phase of the entire fuel cycle. Emissions include all gases which collect in the atmosphere and act to prevent heat which emanates from the earth's surface from leaving the lower atmosphere: $\mathrm{H}_{2} \mathrm{O}, \mathrm{CO}_{2}, \mathrm{CO}, \mathrm{CH}_{4}, \mathrm{~N}_{2} \mathrm{O}$, $\mathrm{NO}, \mathrm{SO}_{2}$, chlorofluorocarbons, volatile organic carbons, radioactive particles, particulate matter, soot and aerosols. Waste by-products include water/brines from natural resources and processes, drilling muds, tailings, leachates, toxic and hazardous waste streams, heavy metals, ash, slag and objects which have reached the end of their useable lives. 


\section{Appendix E}

\section{Biomass Land-use Impacts on Greenhouse Gases}

Some analyses suggest that the production and use of biomass as a fuel has a net zero contribution to greenhouse gas production. These analyses assume that the carbon dioxide $\left(\mathrm{CO}_{2}\right)$ added to the atmosphere during fuel combustion equals the $\mathrm{CO}_{2}$ taken up (i.e., "sunk") by the biofuel feedstock prior to harvest time. Use of biofuel materials affects the greenhouse gas balance by both producing a different mix of greenhouse gases and by changing the $\mathrm{CO}_{2}$ "sinks" through land use changes. In general, each of these effects has a net impact on global warming. ${ }^{1}$

During the biomass fuel cycle, $\mathrm{CO}_{2}$ is removed from the atmosphere as the vegetation used for the biofuel is grown. However, when the fuel is eventually burned, other greenhouse gases such as methane $\left(\mathrm{CH}_{4}\right)$, carbon monoxide (CO), and nonmethane organic compounds (NMOC's) increase. These non- $\mathrm{CO}_{2}$ gases have stronger radiative characteristics than $\mathrm{CO}_{2}$, effectively causing a net increase in greenhouse gas emissions. This impact can be estimated and is usually taken into consideration in fuel-cycle emission studies.

The impact on greenhouse gases over time due to the change in land use is more difficult to estimate. The impact must take into consideration the removal of the initial vegetation as well as the addition of the new biofuel feedstock. The time-integrated impact on $\mathrm{CO}_{2}$ is different between the original ecosystem and the new biofuel system. Thus, there is a net change in carbon emissions to the atmosphere.

To illustrate, consider the impact of clearing a forest to grow biofuel crops. ${ }^{2}$ Biomass is about half carbon, so the more biomass per acre, the more carbon will be sequestered. Forests are estimated to contain an order of magnitude (factor of 10) more carbon than grasslands or crops. After the forest is cut, the carbon in the original vegetation is released when the vegetation is burned, converted to products such as paper, or left to decay. The soil will also lose carbon, usually within five years.

When the forest is cleared, crops are planted. The new crop will take up carbon as it grows, countering some of the $\mathrm{CO}_{2}$ release from the loss of forest. In this example, the crop system will not take up as much carbon as was released when the forest ecosystem was removed. Thus, as long as the crop ecosystem is in place, a net increase of $\mathrm{CO}_{2}$ in the atmosphere has occurred as a result of replacing the forest with crop land.

The opposite situation will occur if crop land is converted to forest, if range land is converted to short-rotation, intensive cultivation trees, or if any high-carbon-content biomass replaces a lower carbon-content biomass.

The important feature of the net release or uptake of $\mathrm{CO}_{2}$ from land use changes is that the quantities of $\mathrm{CO}_{2}$ can be many times larger than the greenhouse gas emissions from the rest of the fuel cycle (feedstock and fuel processing, transportation, and vehicle refueling and combustion). One study estimated that replacing crop land with short-rotation, intensive cultivation trees could result in an uptake of $\mathrm{CO}_{2}$ that would offset about 30 years of greenhouse gas emissions from the production and use of the fuel, including vehicle manufacture. ${ }^{3}$

\section{Notes}

${ }^{1}$ Argonne National Laboratory, Emissions of Greenhouse Gases from the Use of Transportation Fuels and Electricity. Vol 2, Pp. K27-K33.

2In the United States, it is unlikely that forested areas would be cleared for biofuel crops. This situation may, however, occur in other parts of the world.

${ }^{3}$ Argonne National Laboratory, Emissions of Greenhouse Gases from the Use of Transportation Fuels and Electricity, Vol 2, pp. K12 - K13. 


\section{Appendix F}

\section{List of Converters, Original Equipment Manufacturers, and Training Centers}

Table F1. Companies Performing Conversions by State

\begin{tabular}{l|l|ll|c|c}
\hline \multicolumn{1}{c|}{ Company Name } & \multicolumn{1}{c|}{ City } & Fuel Type & Company Name & City & Fuel Type \\
\hline \multicolumn{5}{c}{ ALABAMA } \\
Alabama Gas Corp. & Birmingham & CNG & Suburban Gas, Inc. & Bessemer & LPG \\
Blossman Gas, Inc. & Mobile & LPG & Suburban Propane & Mobile & LPG \\
Bullock Propane & Montgomery & LPG & Suburban Propane & Tuscaloosa & LPG \\
Mobile Gas Service & Mobile & CNG & Synergy Gas Corporation & Albertville & LPG \\
O'Gwynn Inc. & Montgomery & CNG & Synergy Gas Corporation & Gadsden & LPG \\
Precision Sales \& Equipment & Birmingham & LPG & Synergy Gas Corporation & Huntsville & LPG \\
Sonat Ventures & Birmingham & CNG & Synergy Gas Corporation & Jemison & LPG \\
Suburban Equipment & Bessemer & LPG & Teledyne Brown & Huntsville & NG \& LPG \\
Company & & Engineering & & \\
\hline
\end{tabular}

ALASKA

Airport Texaco

Homer

LPG

\section{ARIZONA}

\begin{tabular}{|c|c|c|c|c|c|}
\hline Alternative Fuel Solutions & Scottsdale & CNG & GDR & Prescott & $\mathrm{CNG}$ \\
\hline AmeriGas/Petrolane & Glendale & LPG & $\begin{array}{l}\text { Gas Development } \\
\text { Resources, L.L.C. }\end{array}$ & $\begin{array}{l}\text { Prescott } \\
\text { Valley }\end{array}$ & CNG \\
\hline $\begin{array}{l}\text { Arizona Machine \& } \\
\text { Fabrication Inc. }\end{array}$ & Phoenix & Electric & $\begin{array}{l}\text { North American Fleet } \\
\text { Services }\end{array}$ & Phoenix & NG \\
\hline $\begin{array}{l}\text { Clean Air Fuel Inc., } d / b / a \\
\text { CAFI }\end{array}$ & Phoenix & LNG & Saferide Service & Tempe & LPG \\
\hline Cummins Southwest & Phoenix & CNG & Saferide Service & Tempe & LPG \\
\hline Diversified Technical Services & Phoenix & CNG \& EV & $\begin{array}{l}\text { Southern Arizona Gas, } \\
\text { Inc. }\end{array}$ & Nogales & LPG \\
\hline EcoElectric Corp. & Tucson & Electric & $\begin{array}{l}\text { Southwest Gas } \\
\text { Corporation }\end{array}$ & Phoeniz & CNG \\
\hline $\begin{array}{l}\text { Environmental Fuel Systems, } \\
\text { Inc. }\end{array}$ & Tucson & NG \& LPG & $\begin{array}{l}\text { Southwest Gas } \\
\text { Corporation }\end{array}$ & Tucson & CNG \\
\hline Fountain Hills L P Gas, Inc. & Fountain Hills & LPG & Williams Detroit Diesel & Phoenix & CNG \\
\hline
\end{tabular}

\section{ARKANSAS}

\begin{tabular}{|c|c|c|c|c|c|}
\hline AZ Industries & Hardy & CNG,LPG,EV & Matthews, Inc. & Dumas & LPG \\
\hline AmeriGas & Morrilton & LPG & Petrolane Gas Service & McNeil & LPG \\
\hline Arkansas Louisiana Gas Co. & Little Rock & NG & Qualpaw Texaco & Little Rock & CNG \\
\hline $\begin{array}{l}\text { Arkansas Oklahoma Gas } \\
\text { Corporation }\end{array}$ & Fort Smith & NG & Southern LP Gas Inc. & Dequeen & LPG \\
\hline Arkansas Western Gas Co. & Fayettville & NG & Summers Butane & Lincoln & LPG \\
\hline Butane Gas, Inc. & Mountainburg & LPG & Synergy Gas Corporation & Clarksville & LPG \\
\hline Cabot Propane Company, & Cabot & LPG & Synergy Gas Corporation & Crossett & LPG \\
\hline
\end{tabular}


Table F1. Companies Performing Conversions by State (Continued)

\begin{tabular}{l|l|l|l|l|l|l}
\hline Company Name & City & Fuel Type & Company Name & City & Fuel Type \\
\hline
\end{tabular}

ARKANSAS (Continued)

\begin{tabular}{|c|c|c|c|c|}
\hline Envirotech & Sherwood & $\mathrm{CNG}$ & Thermagas & $\begin{array}{l}\text { North Little } \\
\text { Rock }\end{array}$ \\
\hline Fricks Butane Gas Co., Inc. & Texarkana & LPG & Whitey's Truck Center & Little Rock \\
\hline Gray's Petroleum & Dequeen & LPG & & \\
\hline
\end{tabular}

\begin{tabular}{|c|c|c|c|c|c|}
\hline $\begin{array}{l}\text { 4E Technologies, Inc. } \\
\text { (Ecotrans) }\end{array}$ & Los Angeles & CNG & Kamps Propane & Manteca & LPG \\
\hline AC Propulsion Inc. & San Dimas & Electric & Kamps Propane & Oakley & LPG \\
\hline APS Systems & Oxnard & Electric & Kaylor Energy Products & $\begin{array}{l}\text { Boulder } \\
\text { Creek }\end{array}$ & Electric \\
\hline APS Systems & Santa Barbara & Electric & Lasher Auto Center & Woodland & $\mathrm{CNG}$ \\
\hline $\begin{array}{l}\text { Advanced Electric Car } \\
\text { Technology (HABA Electric) }\end{array}$ & Van Nuys & Electric & Lorensen Propane Gas & Los Banos & LPG \\
\hline Alternative Fuel Technologies & $\begin{array}{l}\text { Huntington } \\
\text { Beach }\end{array}$ & CNG & MTK Gas & Bakersfield & LPG \\
\hline American Chevrolet & Modesto & $\mathrm{CNG}$ & MendoMotiv & Albion & Electric \\
\hline American Gas \& Technology & San Jose & NG \& LPG & Mike's Autocare & San Mateo & Electric \\
\hline $\begin{array}{l}\text { Automotive Diagnostic } \\
\text { Service }\end{array}$ & Sacramento & CNG \& LPG & Mission Valley Ford & San Jose & CNG \\
\hline $\mathrm{BKM}$, Inc. & San Diego & CNG & $\begin{array}{l}\text { Mutual Liquid Gas \& } \\
\text { Equipment Co., Inc. }\end{array}$ & Gardena & LPG \\
\hline Ballard Gas Service, Inc. & San Jacinto & LPG & NGV Ecotrans & Los Angeles & $\mathrm{CNG}$ \\
\hline $\begin{array}{l}\text { Battery Automated } \\
\text { Transportation International }\end{array}$ & Burbank & Electric & North Valley Propane & Willows & LPG \\
\hline Big $\mathrm{H}$ Inc. & El Cajon & CNG & PACA/TEECO Products & Sacramento & CNG \& LPG \\
\hline Big Valley Ford & Stockton & NG & $\begin{array}{l}\text { Pacific Utility Body } \\
\text { Company }\end{array}$ & San Lorenzo & CNG \\
\hline Burkhardt Turbines & Fort Bragg & Electric & $\begin{array}{l}\text { Paul Rossi Performance } \\
\text { Engrg. }\end{array}$ & Fallbrook & CNG \\
\hline$C \& M$ & Visalia & NG & $\begin{array}{l}\text { Petrolane Conversion } \\
\text { Center }\end{array}$ & $\begin{array}{l}\text { Santa Fe } \\
\text { Springs }\end{array}$ & CNG \& LPG \\
\hline CNG Automotive & Fresno & $\mathrm{CNG}$ & Phillips Performance E.V. & $\begin{array}{l}\text { City of } \\
\text { Industry }\end{array}$ & Electric \\
\hline $\begin{array}{l}\text { California Alternative } \\
\text { Propulsion Company } \\
\text { (CAPCo) }\end{array}$ & Los Angeles & Electric & Quality Lift Trucks & Chula Vista & $\mathrm{CNG}$ \\
\hline California Electric Cars Inc. & Seaside & Electric & Replica Roadsters & Gardena & Electric \\
\hline $\begin{array}{l}\text { California Natural Gas } \\
\text { Vehicle Coalition }\end{array}$ & Sacramento & NG & Replica Roadsters & $\begin{array}{l}\text { Rolland } \\
\text { Heights }\end{array}$ & Electric \\
\hline $\begin{array}{l}\text { Chase Chrysler Plymouth } \\
\text { Suzuki }\end{array}$ & Stockton & $\mathrm{CNG}$ & SMUD & Sacramento & Electric \\
\hline Clean Air Partners, Inc. & San Diego & CNG & $\begin{array}{l}\text { Sam Louis Butane } \\
\text { Division of Delta Liquid } \\
\text { Energy }\end{array}$ & Santa Paula & LPG \\
\hline Coast Gas & Bakersfield & LPG & $\begin{array}{l}\text { Sam Louis Butane } \\
\text { Division of Delta Liquid } \\
\text { Energy }\end{array}$ & Ventura & LPG \\
\hline Coast Gas & Lemoore & LPG & $\begin{array}{l}\text { San Diego Electric } \\
\text { Automobile Co. }\end{array}$ & Lakeside & Electric \\
\hline
\end{tabular}




\begin{tabular}{l|l|l|l|l|l|l|}
\hline Company Name & City & Fuel Type & Company Name & City & Fuel Type \\
\hline
\end{tabular}

CALIFORNIA (Continued)

\begin{tabular}{|c|c|c|c|c|c|}
\hline $\begin{array}{l}\text { Commercial Fleet Services } \\
\text { Inc. }\end{array}$ & Eldorado Hills & CNG \& LPG & San Diego Gas \& Electric & San Diego & CNG \\
\hline $\begin{array}{l}\text { Crossroads Auburn Auto } \\
\text { Center }\end{array}$ & Auburn & CNG & Sierra Detroit Diesel & San Leandro & CNG \\
\hline Dassel's Petrolane, Inc. & Hanford & LPG & Suburban Propane & Bakersfield & LPG \\
\hline $\begin{array}{l}\text { Delta Liquid Energy/St. } \\
\text { Louis Butane }\end{array}$ & Buellton & LPG & Suburban Propane & Placentia & LPG \\
\hline $\begin{array}{l}\text { Delta Liquid Energy/St. } \\
\text { Louis Butane }\end{array}$ & Lancaster & LPG & $\begin{array}{l}\text { Suburban Propane } \\
\text { (Fabrication \& } \\
\text { Construction) }\end{array}$ & $\begin{array}{l}\text { Golden } \\
\text { State }\end{array}$ & LPG \\
\hline $\begin{array}{l}\text { Delta Liquid Energy/St. } \\
\text { Louis Butane }\end{array}$ & Paso Robles & LPG & Sun Toys & Santa Cruz & Electric \\
\hline $\begin{array}{l}\text { Delta Liquid Energy/St. } \\
\text { Louis Butane }\end{array}$ & Santa Paula & LPG & TDM Conversions & Ontario & CNG \& M85 \\
\hline $\begin{array}{l}\text { Delta Liquid Energy/St. } \\
\text { Louis Butane }\end{array}$ & Victorville & LPG & Teeco Products, Inc. & Sacramento & CNG \& LPG \\
\hline Dorn's Gas & Riverdale & LPG & TerraFuel System, Inc. & Inglewood & CNG \\
\hline $\begin{array}{l}\text { East Bay Ford Truck Sales, } \\
\text { Inc. }\end{array}$ & Oakland & $\mathrm{CNG}$ & U.S. Electricar Inc. & Los Angeles & Electric \\
\hline Electric Vehicle Inc. & Mountain View & Electric & U.S. Electricar Inc. & Redlands & Electric \\
\hline $\begin{array}{l}\text { Envirotech Equipment } \\
\text { Company }\end{array}$ & Van Nuys & CNG \& M85 & U.S. Electricar Inc. & Santa Rosa & Electric \\
\hline Eyeball Engineering & Fontana & Electric & United Propane Corp. & Oildale & LPG \\
\hline Fresno Auto Shop & Fresno & CNG & Valine Carbueration & Chico & LPG \\
\hline Globe Gas Corp. & Long Beach & LPG & $\begin{array}{l}\text { Valley Detroit Diesel } \\
\text { Allison, Inc. }\end{array}$ & Bakersfield & NG LPG Alc \\
\hline Green Fuels Technologies & Berkeley & CNG \& LPG & $\begin{array}{l}\text { Valley Detroit Diesel } \\
\text { Allison, Inc. }\end{array}$ & $\begin{array}{l}\text { City of } \\
\text { Industry }\end{array}$ & NG LPG Alc \\
\hline Green Motorworks & N. Hollywood & Electric & $\begin{array}{l}\text { Valley Detroit Diesel } \\
\text { Allison, Inc. }\end{array}$ & El Cajon & NG LPG Alc \\
\hline Hawthorne Power Systems & San Diego & CNG \& LPG & $\begin{array}{l}\text { Valley Detroit Diesel } \\
\text { Allison, Inc. }\end{array}$ & Fresno & NG LPG Alc \\
\hline Herb Adams V.S.E. & Carmel & Electric & Van Wyk's of Bakersfield & Bakersfield & CNG \\
\hline IMPCO Technologies, Inc. & Cerritos & CNG & Venus Engineering & Bakersfield & LPG \& EV \\
\hline Kamps Propane & Elk Grove & LPG & VoltAge, Inc. & Gardena & Electric \\
\hline Kamps Propane & Haywood & LPG & West Coast Propane & Van Nuys & LPG \\
\hline Western Propane Service & Santa Maria & LPG & & & \\
\hline \multicolumn{6}{|c|}{ COLORADO } \\
\hline Agland Inc. & Eaton & LPG & Green Brothers Gas & Brighton & LPG \\
\hline AmeriGas & Englewood & LPG & $\mathrm{J}-\mathrm{W}$ Operating Company & Wray & CNG \\
\hline Amoco Production Co. & Durango & CNG & $\begin{array}{l}\text { Natural Fuels } \\
\text { Corporation }\end{array}$ & Denver & CNG \\
\hline $\begin{array}{l}\text { Arapahoe Environmental } \\
\text { Fuels Inc. }\end{array}$ & Englewood & CNG & Navahoe Butane & Cortez & LPG \\
\hline $\begin{array}{l}\text { Butane Power \& Equipment } \\
\text { Co. }\end{array}$ & Fort Morgam & LPG & Phillips 66 Propane & Brighton & LPG \\
\hline Cryenco & Denver & LNG & Phillips 66 Propane & $\begin{array}{l}\text { Colorado } \\
\text { Springs }\end{array}$ & LPG \\
\hline
\end{tabular}




\begin{tabular}{|c|c|c|c|c|c|}
\hline Company Name & City & Fuel Type & Company Name & City & Fuel Type \\
\hline \multicolumn{6}{|c|}{ COLORADO (Continued) } \\
\hline Eagle Engineering, Inc. & Longmont & Electric & Phillips 66 Propane & $\begin{array}{l}\text { Commerce } \\
\text { City }\end{array}$ & LPG \\
\hline Ellen Equipment Corp. & Aurora & LPG & Phillips 66 Propane & Fort Collins & LPG \\
\hline Ellen Equipment Corp. & Colorado Springs & LPG & $\begin{array}{l}\text { Public Service Company } \\
\text { of Colorado }\end{array}$ & Denver & CNG \\
\hline Ellen Equipment Corp. & Fort Collins & LPG & $\begin{array}{l}\text { Sterling Oil \& Gas Co., } \\
\text { Inc. }\end{array}$ & Sterling & LPG \\
\hline Fraley \& Company, Inc. & Cortez & LPG & Stewart \& Stevenson & $\begin{array}{l}\text { Commerce } \\
\text { City }\end{array}$ & $\mathrm{CNG}$ \\
\hline Glaser Gas, Inc. & Calhan & LPG & Suburban Propane & Lakewood & LPG \\
\hline Glaser Gas, Inc. & Colorado Spring & LPG & World County Garage & Greeley & LPG \\
\hline
\end{tabular}

\section{CONNECTICUT}

\begin{tabular}{|c|c|c|c|c|c|}
\hline Bemer Petroleum Corp. & Glastonbury & LPG & Hocon Gas, Inc. & Waterbury & LPG \\
\hline Buckley Energy Group & Bridgeport & LPG & $\begin{array}{l}\text { Leahy's Metered Gas } \\
\text { Service, Inc. }\end{array}$ & Danbury & LPG \\
\hline $\begin{array}{l}\text { Connecticut Natural Gas } \\
\text { Corp. }\end{array}$ & Hartford & NG & $\begin{array}{l}\text { Natural Gas Conversions } \\
\text { Inc. }\end{array}$ & Bristol & CNG \\
\hline Connversions of Connecticut & Southington & CNG \& LPG & $\begin{array}{l}\text { Naugatuck Valley } \\
\text { Community Technical } \\
\text { College }\end{array}$ & Waterbury & CNG, EV, LPG \\
\hline Grasmere Sunoco & Fairfield & LPG & $\begin{array}{l}\text { Yankee Gas Service } \\
\text { Company }\end{array}$ & Meriden & CNG \\
\hline Hocon Gas, Inc. & Norwalk & LPG & & & \\
\hline \multicolumn{6}{|c|}{ DELAWARE } \\
\hline Chesapeake Utilities Corp. & Dover & NG \& LPG & Suburban Propane & Millsboro & LPG \\
\hline Suburban Propane & Dover & LPG & TDM Conversions & New Castle & CNG \& M85 \\
\hline \multicolumn{6}{|c|}{ FLORIDA } \\
\hline Alternative Fuel Systems & Pembroke Pines & LPG & Mobile Gas & Jacksonville & LPG \\
\hline $\begin{array}{l}\text { Alternative Fuels Technology } \\
\text { Corp. }\end{array}$ & & $\mathrm{CNG}$ & Motorfuelers, Inc. & Clearwater & NG \& LPG \\
\hline AmeriGas & Dundee & LPG & $\begin{array}{l}\text { Natural Gas Conversions } \\
\text { Inc. }\end{array}$ & Jupiter & CNG \\
\hline AmeriGas & Orlando & LPG & Peoples Gas, Inc. & Tampa & CNG \& LPG \\
\hline Atlantic Propane & Lantana & LPG & $\begin{array}{l}\text { Sarasota County Sheriff's } \\
\text { Department }\end{array}$ & Sarasota & LPG \\
\hline $\begin{array}{l}\text { Carburation Labs } \\
\text { International, Inc. }\end{array}$ & Miami & NG & Solar Car Corporation & Melbourne & CNG \& LPG \\
\hline $\begin{array}{l}\text { Conversion Labs } \\
\text { International }\end{array}$ & Miami & NG & Solar Trike and Car & $\begin{array}{l}\text { Big Pine } \\
\text { Key }\end{array}$ & EV/Solar \\
\hline $\begin{array}{l}\text { Donnini Enterprises Shell } \\
\text { Station }\end{array}$ & Lake Park & CNG & Suburban Propane & Sarasota & LPG \\
\hline Dyno Tune & Jacksonville & CNG \& LPG & Synergy Gas Corporation & $\begin{array}{l}\text { West Paim } \\
\text { Beach }\end{array}$ & LPG \\
\hline Hillsboro Gas Company & Tampa & LPG & Tri-County Gas, Inc. & Stuart & LPG \\
\hline Krutsinger Services, Inc. & Tampa & LPG & U.S. Electricar Inc. & $\begin{array}{l}\text { Riviera } \\
\text { Beach }\end{array}$ & Electric \\
\hline
\end{tabular}




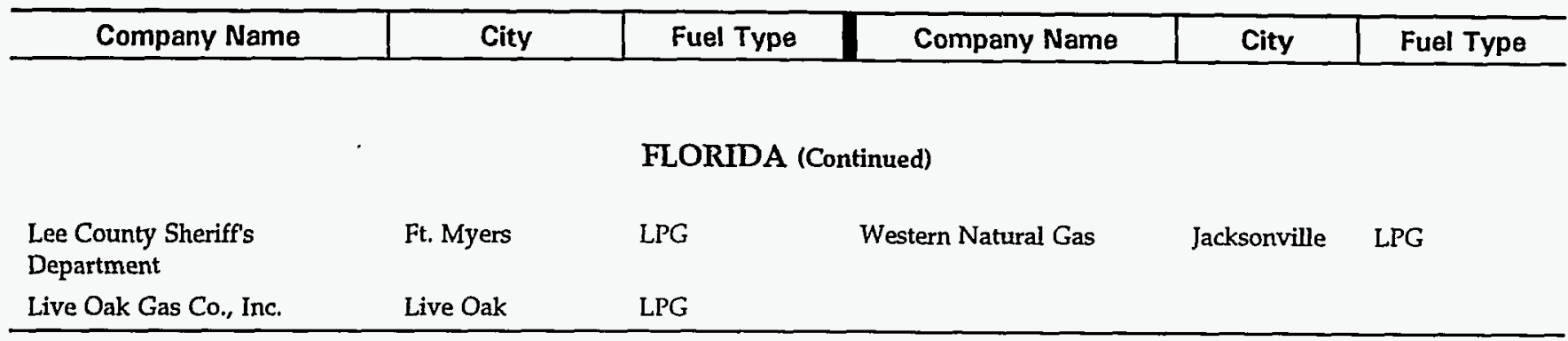

\section{GEORGIA}

\begin{tabular}{|c|c|c|c|c|c|}
\hline Atlanta Gas Light Co. & Atlanta & NG & $\begin{array}{l}\text { Georgia Gas Distributors, } \\
\text { Inc. }\end{array}$ & Atlanta & LPG \\
\hline Blossman Gas, Inc. & Roopville & LPG & NGV Southeast & Riverdale & CNG \\
\hline Combustion Labs & Forest Park & NG & $\begin{array}{l}\text { Petrolane Propane Carb. } \\
\text { Center }\end{array}$ & Doraville & LPG \\
\hline Cryogenic Services, Inc. & Canton & LNG & Southern Natural Gas & Riverdale & CNG \\
\hline Dixie Meter \& Service & Martinez & LPG & & & \\
\hline
\end{tabular}

\section{HAWAII}

Gasco Clean Air

Honolulu

LPG

\section{IDAHO}

\begin{tabular}{llll} 
Al's Car Care, Inc. & Boise & CNG & Interstate Gas Service \\
Global Light \& Power & Sandpoint & Electric & \\
\hline
\end{tabular}

\section{ILLINOIS}

Alternative Fuels Limited

Cady Oil Co.

Carburation Labs of Midwest

Century Alternate Fuel

Systems

Diversified Fleet Services

Dual Fuel Systems, Inc.

EMD (Electro Motive

Division)

Electric Auto Crafters

Illinois Industrial Equipment

Company

Illinois Industrial Equipment

Company

Institute of Gas Technology (IGT)
Skoki

Peoria Heights

Des Plaines

Chicago

Napeville

Naperville

La Grange

Batavia

Mulcona

Orland Park

Des Plaines

CNG

NG

LPG

NG \& LPG

CNG \& LPG

LNG

Electric

CNG

CNG

CNG
Iowa Illinois Gas \& Electric Company

L.P. Gas Equipment

Midwestern Propane Gas Co., Inc.

Northern Illinois Gas

Pattan Industries

Patten Power Systems

Skelgas, Inc.

Soleq

Thompson's Gas, Inc.

Transportation Systems, Inc.
Rock Island

CNG

Arlinton

Heights

Belleville

Naperville

Elmhurst

Elmhurst

CNG

Elmhurst

CNG

CNG \& LPG

Chicago Electric

Belleville LPG

Elk Grove CNG \& LPG Village

\begin{tabular}{|c|c|c|}
\hline Clarklift of Indiana & Indianapolis & CNG \& LPG \\
\hline Greene's Auto Service & Indianapolis & CNG \& LPG \\
\hline $\begin{array}{l}\text { Mike Anderson } \\
\text { Pontiac-Olds-GMC-Mazda }\end{array}$ & Logansport & CNG \\
\hline
\end{tabular}

Northern Indiana Public Service Co. (NIPSCO)

SISCO Truck Center

Southern Indiana Gas \& Electric Co.
Hammond

Evansville

Evansville
CNG \& LNG

CNG \& LPG

CNG 
Table F1. Companies Performing Conversions by State (Continued)

\begin{tabular}{c|c|c|c|c|c}
\hline Company Name & City & Fuel Type & Company Name & City & Fuel Type \\
\hline
\end{tabular}

IOWA

Diversified Industries

Diversich Industries

\begin{abstract}
Anadardo Trading Company
\end{abstract}
B\&L Engine

B.E.A.R. Automotive

Carson's Mechanical Services

Chance Coach, Inc.

Dee's Auto \& Truck Service

Flint Hills LP-Gas Company

Fuel Tec, United

Lovett's L.P. Gas Service

Mid-Continent LP Service

Mid-Kansas Propane Inc.

National Fuel Systems, Inc.
Fort Dodge

\section{Liberal}

Goodland

Wichita

Great Bend

Wichita

Arkansas City

Alma

S. Hutchinson

Junction City

Great Bend

Newton

Kansas City
LPG

\section{KANSAS}

LPG

LPG

LPG

LPG

CNG \& LPG

LPG

LPG

LPG

LPG

LPG

LPG

CNG \& LPG

\section{Payne Oil Company \\ Payne Oil Company \\ Propane Center \\ Ramsey Propane \\ Southwest Gas}

Equipment Co., Inc.

State Avenue Goodyear

Sterling Butane Inc.

Tenpenny's Auto Body

Wallace County Coop

Wanklyn Oil Company

Yosemite Sam's

$\begin{array}{ll}\text { Concordia } & \text { LPG } \\ \text { Salina } & \text { LPG } \\ \text { Clay Center } & \text { LPG } \\ \text { Hutchinson } & \text { LPG } \\ \text { Liberal } & \text { LPG } \\ & \\ \text { Kansas City } & \text { CNG } \\ \text { Sterling } & \text { LPG } \\ \text { Nortonville } & \text { LPG } \\ \text { Sharon } & \text { LPG } \\ \text { Springs } & \\ \text { Frankfort } & \text { LPG } \\ \text { Topeka } & \text { LPG }\end{array}$

Concordia LPG

LPG

Clay Center LPG

Hutchinson LPG

LPG

CNG

$P G$

PG

$P G$

$P G$

PG

\section{KENTUCKY}

\begin{tabular}{llllll} 
All-State Ford Truck Sales & Louisville & LPG & Louisville Gas \& Electric & Louisville & CNG \\
Automotive Inc. & Owensboro & CNG & United Transportation & Lexington & LPG \\
Bachman NGV & Louisville & CNG & & & \\
\hline
\end{tabular}

\section{LOUISIANA}

\begin{tabular}{|c|c|c|c|c|c|}
\hline $\begin{array}{l}\text { American Natural Gas } \\
\text { Power, Inc. }\end{array}$ & Choctaw & CNG \& LNG & G.M. Barnadol \& Son & $\begin{array}{l}\text { Baton } \\
\text { Rouge }\end{array}$ & LPG \\
\hline $\begin{array}{l}\text { Cajun Propane of Lafayette, } \\
\text { Inc. }\end{array}$ & Scott & LPG & $\begin{array}{l}\text { Koerner's Mobil/CNG } \\
\text { Services }\end{array}$ & Shreveport & CNG \\
\hline Cordill Propane Service & Winnsboro & CNG \& LPG & LGS Intrastate Company & Marrero & CNG \\
\hline Cropmate Company & Jeanerette & LPG & LGS Intrastate Company & Monroe & CNG \\
\hline Cropmate Company & New Roads & LPG & $\begin{array}{l}\text { LGS Natural Gas } \\
\text { Company }\end{array}$ & Marrero & CNG \\
\hline Cropmate Company & Thibodaux & LPG & $\begin{array}{l}\text { LGS Natural Gas } \\
\text { Company }\end{array}$ & Monroe & CNG \\
\hline EcoGas, Inc. & Baton Rouge & CNG \& LNG & Petrolane & $\begin{array}{l}\text { New } \\
\text { Orleans }\end{array}$ & LPG \\
\hline EcoGas, Inc. & Hanahan & CNG \& LNG & $\begin{array}{l}\text { Reagan Equipemnt } \\
\text { Company, Inc. }\end{array}$ & Harvey & CNG \\
\hline ExproFuels & Harahan & NG \& LPG & Stewart \& Stevenson & Harvie & CNG \\
\hline \multicolumn{6}{|c|}{ MAINE } \\
\hline JM \& Sons & Blaine & \multicolumn{4}{|l|}{ LPG } \\
\hline \multicolumn{6}{|c|}{ MARYLAND } \\
\hline $\begin{array}{l}\text { Baltimore Gas \& Electric } \\
\text { Company }\end{array}$ & Baltimore & NG & $\begin{array}{l}\text { Independence Truck } \\
\text { Body }\end{array}$ & Clinton & CNG \& LPG \\
\hline
\end{tabular}


Table F1. Companies Performing Conversions by State (Continued)

\begin{tabular}{l|l|l|l|l|l|l|}
\hline Company Name & City & Fuel Type & Company Name & City & Fuel Type \\
\hline
\end{tabular}

MARYLAND (Continued)

\begin{tabular}{|c|c|c|c|c|}
\hline Chesapeake Automotive & Reisterstown & CNG & JL Associates, Inc. (JLA) & $\begin{array}{l}\text { Patuxent } \\
\text { River }\end{array}$ \\
\hline $\begin{array}{l}\text { Great Lakes Truck } \\
\text { Equipment }\end{array}$ & Clinton & CNG & Suburban Propane & $\begin{array}{l}\text { Reisters- } \\
\text { town }\end{array}$ \\
\hline
\end{tabular}

\begin{tabular}{|c|c|c|c|c|c|}
\hline Bay State Gas & Brockton & CNG \& LPG & $\begin{array}{l}\text { Electric Vehicles of } \\
\text { America }\end{array}$ & Maynard & Electric \\
\hline Bay State Gas & Springfield & CNG \& LPG & $\begin{array}{l}\text { GreenWheels Electric Car } \\
\text { Company }\end{array}$ & Beverly & Electric \\
\hline $\begin{array}{l}\text { Bob Batson Electric Vehicles } \\
\text { of America }\end{array}$ & Maynard & Electric & $\begin{array}{l}\text { Hank's Southeastern } \\
\text { Propane, Inc. }\end{array}$ & Westport & LPG \\
\hline Boston Gas Company & West Rockbury & CNG & Holden Bottled Gas, Inc. & Peabody & LPG \\
\hline Bradford Truck Center & Everett & CNG & Nat-Gas Conversions, Inc. & Millbery & NG \& LPG \\
\hline Brodie & Lawrence & NG \& LPG & Power Products Inc. & Wakefield & $\mathrm{CNG}$ \\
\hline Brodie & Sharon & NG \& LPG & $\begin{array}{l}\text { Solectria Electonics } \\
\text { Division }\end{array}$ & Wilmington & Electric \\
\hline $\begin{array}{l}\text { Carpenter Auto \& Truck } \\
\text { Repair }\end{array}$ & Kingston & LPG & Tecogen, Inc. & Marlboro & CNG \\
\hline Colonial Gas Co. & Lowell & NG & $\begin{array}{l}\text { Wellington Baker } \\
\text { Associates }\end{array}$ & $\begin{array}{l}\text { North } \\
\text { Reading }\end{array}$ & CNG \& LPG \\
\hline Dudley Automotive Services & Arlington & CNG \& LPG & $\begin{array}{l}\text { Westfield Gas \& Electric } \\
\text { Light Department }\end{array}$ & Westfield & CNG \& LPG \\
\hline
\end{tabular}

\section{MICHIGAN}

\begin{tabular}{|c|c|c|c|c|c|}
\hline Battle Creek Gas Co. & Battle Creek & CNG & Multi-Fuel Corp. & Lake Orion & CNG \\
\hline CH 4 Technologies & Warren & CNG & Nolff's Carbueration Inc. & Wayne & CNG \& LPG \\
\hline Cardinal Automotive Inc. & Sterling Heights & CNG & PAS, Inc. & Troy & Alcl \\
\hline Fuel Concepts, Inc. & Melvindale & NG & $\begin{array}{l}\text { Rhoda Gas Energy } \\
\text { Systems Inc. }\end{array}$ & Oak Park & CNG \& LPG \\
\hline Intelligent Controls, Inc. & Novi & CNG & Scherer Truck Equipment & $\begin{array}{l}\text { Auburn } \\
\text { Hills }\end{array}$ & CNG \& LPG \\
\hline Intervale Propane Company & Detroit & LPG & $\begin{array}{l}\text { Southeastern Michigan } \\
\text { Gas Company }\end{array}$ & Port Huron & CNG \\
\hline L.P. Gas Equipment & Romulus & CNG \& LPG & $\begin{array}{l}\text { Southeastern Michigan } \\
\text { Gas Company }\end{array}$ & $\begin{array}{l}\text { Three } \\
\text { Rivers }\end{array}$ & CNG \\
\hline $\begin{array}{l}\text { Mascotech Vehicle } \\
\text { Operations }\end{array}$ & Auburn Hills & NG & Spartan Motors & Charlotte & Electric \\
\hline $\begin{array}{l}\text { Mascotech Vehicle } \\
\text { Operations }\end{array}$ & Detroit & NG & $\begin{array}{l}\text { Starghill Alternative } \\
\text { Energy Corp. }\end{array}$ & Detroit & NG \& LPG \\
\hline Michigan Gas Company & Niles & CNG & TDM Conversions & $\begin{array}{l}\text { Auburn } \\
\text { Hills }\end{array}$ & CNG \& M85 \\
\hline Modern Engineering & Southeastern & CNG \& EV & $\begin{array}{l}\text { TDM, Technologies and } \\
\text { World Conversions }\end{array}$ & Livoria & NG, LPG, EV \\
\hline \multicolumn{6}{|c|}{ MINNESOTA } \\
\hline Acme Carburetion, Inc. & Mankato & CNG \& LPG & Owatonna Public Utilities & Owatonna & CNG \& LPG \\
\hline $\begin{array}{l}\text { Carburation \& Turbo } \\
\text { Systems, Inc. }\end{array}$ & Shakopee & NG \& LPG & $\begin{array}{l}\text { Schwann's Sales } \\
\text { Enterprise }\end{array}$ & Marshall & LPG \\
\hline
\end{tabular}


Table F1. Companies Performing Conversions by State (Continued)

\begin{tabular}{l|c|c|c|c|c|c|}
\hline Company Name & City & Fuel Type & Company Name & City & Fuel Type \\
\hline
\end{tabular}

MINNESOTA (Continued)

\begin{tabular}{|c|c|c|c|c|c|}
\hline $\begin{array}{l}\text { Minnegasco } \\
\text { Natrogas Inc. }\end{array}$ & $\begin{array}{l}\text { Saint Louis Park } \\
\text { Minneapolis }\end{array}$ & $\begin{array}{l}\text { CNG } \\
\text { LNG \& LPG }\end{array}$ & Suburban Propane & St. Cloud & LPG \\
\hline \multicolumn{6}{|c|}{ MISSISSIPPI } \\
\hline American Warrior, Inc & Jackson & $\mathrm{CNG}$ & Graeber Brothers, Inc. & Senatobia & LPG \\
\hline Blossman Gas, Inc. & Ocean Springs & LPG & Mississippi Valley Gas & Jackson & CNG \\
\hline C.P. House Gas Co. & Cleveland & LPG & $\begin{array}{l}\text { Moulden Supply } \\
\text { Company }\end{array}$ & Jackson & CNG \& LPG \\
\hline Graeber Brothers, Inc. & Clarksdale & LPG & $\begin{array}{l}\text { Pittman Bros. Gas Co., } \\
\text { Inc. }\end{array}$ & Corinth & LPG \\
\hline Graeber Brothers, Inc. & Marks & LPG & Wilmutt Gas & Hattiesburg & $\mathrm{CNG}$ \\
\hline \multicolumn{6}{|c|}{ MISSOURI } \\
\hline Bowgen Fuel Systems, Inc. & Springfield & CNG & GASCO Propane & Eldon & LPG \\
\hline City Utilities of Springfield & Springfield & $\mathrm{CNG}$ & Laclede Gas Company & St. Louis & CNG \\
\hline Coots Carburetion \& Service & Lathrop & LPG & Missouri Propane & Carrollton & LPG \\
\hline Cummins Gateway, Inc. & St. Louis & CNG & Phillips 66 Propane & St. Louis & LPG \\
\hline Dale's Little Propane Garage & Ozark & LPG & $\begin{array}{l}\text { Phillips } 66 \text { Propane } \\
\text { Company }\end{array}$ & Flint Hill & LPG \\
\hline Eldon Public Schools & Eldon & LPG & $\begin{array}{l}\text { Tiger Tractor } \\
\text { Corporation, The }\end{array}$ & $\begin{array}{l}\text { Lee's } \\
\text { Summit }\end{array}$ & CNG \\
\hline Ferrellgas & Liberty & LPG & Tristate Tank Corp. & Kansas City & CNG \& LPG \\
\hline
\end{tabular}

\section{MONTANA}

Butane Power \& Equipment Glendive LPG Quality Auto Service Butte

Co.

Demarios Oldsmobile - GMC

Farr Automotive Specialists

Missoula

CNG \& LPG

Sunset Auto Repair

Kalispell CNG

Loren's Auto Repair

Bozeman

$\mathrm{CNG}$

Truck Suppliers

Glendive

CNG

Universal Tire \&

Baker

$\mathrm{CNG}$

Montana Power Company

Butte

CNG

Alignment

Western Radiator and

Helena

CNG

Northern Energy, Inc.

Bozeman

LPG

Automotive

Billings

CNG

Northern Energy, Inc.

Missoula

LPG

\section{NEBRASKA}

- Automotive Sales and Service

McCook

LPG

Lee's Propane \& RV

Lincoln

CNG \& LPG

Carlson Home \& Auto

Wausa

LPG

Service, Inc.

Metropolitan Utilities

Omaha

CNG

Darrel's Amoco

Omaha

CNG

$\begin{array}{ll}\text { Nebraska Alternate Fuels, } & \text { Grand } \\ \text { Inc. } & \text { Island }\end{array}$

CNG \& LPG

\section{NEVADA}

$\begin{array}{llll}\text { Car Doctor Inc., The Las Vegas } \quad \text { CNG } & \begin{array}{l}\text { Southwest Gas } \\ \text { Corporation }\end{array} & \text { Las Vegas CNG }\end{array}$


Table F1. Companies Performing Conversions by State (Continued)

\begin{tabular}{|c|c|c|c|c|c|}
\hline Company Name & City & Fuel Type & Company Name & City & Fuel Typo \\
\hline \multicolumn{6}{|c|}{ NEVADA (Continued) } \\
\hline Greg's Garage & Reno & CNG & $\begin{array}{l}\text { Yellow, Checker, Star Cab } \\
\text { Company }\end{array}$ & Las Vegas & LPG \\
\hline $\begin{array}{l}\text { Sierra Pacific Power } \\
\text { Company }\end{array}$ & Reno & CNG & & & \\
\hline \multicolumn{6}{|c|}{ NEW HAMPSHIRE } \\
\hline Eastern Auto \& Truck Repair & Manchester & CNG \& LPG & $\begin{array}{l}\text { New England Propane } \\
\text { Truck, Inc. }\end{array}$ & Merrimack & LPG \\
\hline \multicolumn{6}{|c|}{ NEW JERSEY } \\
\hline Ace Gas Co. & Wrightstown & LPG & $\begin{array}{l}\text { Innovative Quality } \\
\text { Services }\end{array}$ & Hoboken & CNG \\
\hline $\begin{array}{l}\text { Atlantic Detroit } \\
\text { Diesel-Allison, Inc. }\end{array}$ & Lodi & CNG,LPG,Alc & Propane Equipment Corp. & Tinton Falls & CNG \& LPG \\
\hline Automotive Concepts & Bellmaw & CNG & SLP Engineering & Toms River & CNG \& LPG \\
\hline Country Gas Service Inc. & Maple Shade & LPG & Star Gas Service & $\begin{array}{l}\text { Maple } \\
\text { Shade }\end{array}$ & LPG \\
\hline Eastern Propane Corp. & Oak Ridge & LPG & $\begin{array}{l}\text { Suburban Propane } \\
\text { Conversion Center }\end{array}$ & Kenvil & LPG \\
\hline IQS, Inc. & Hoboken & CNG & Welsh Technologies & River Edge & LPG \\
\hline
\end{tabular}

\begin{tabular}{|c|c|c|c|c|c|}
\hline Akela West Industries & Deming & Electric & National Propane & Clovis & LPG \\
\hline CNG Corporation & Albuquerque & CNG \& LPG & $\begin{array}{l}\text { Petrolane/An AmeriGas } \\
\text { Co. }\end{array}$ & Tucumcari & LPG \\
\hline Eddins-Walcher & Hobbs & LPG & Remco, Inc. & Roswell & CNG \& LPG \\
\hline Ellen Equipment Corp. & Albuquerque & LPG & Stewart \& Stevenson & Albuquerque & CNG \\
\hline $\begin{array}{l}\text { Energy Conversion } \\
\text { Corporation }\end{array}$ & Santa $\mathrm{Fe}$ & CNG \& LNG & $\begin{array}{l}\text { Stewart \& Stevenson } \\
\text { Power, Inc. }\end{array}$ & Farmington & CNG \\
\hline $\begin{array}{l}\text { Gas Company on New } \\
\text { Mexico }\end{array}$ & Albuquerque & \multicolumn{4}{|l|}{ CNG \& LPG } \\
\hline \multicolumn{6}{|c|}{ NEW YORK } \\
\hline 4 Wheel Driveline Systems & Staten Island & CNG & $\begin{array}{l}\text { Marcus Whittman School } \\
\text { District - Garage }\end{array}$ & Gorham & CNG \\
\hline $\begin{array}{l}\text { Alternative Fuels Technology } \\
\text { Corp. }\end{array}$ & Buffalo & $\mathrm{CNG}$ & MetroPane, Inc. & S. Cairo & CNG \& LPG \\
\hline Brooklyn Union Gas Co. & Brooklyn & CNG & MetroPane, Inc. & $\begin{array}{l}\text { Staten } \\
\text { Island }\end{array}$ & CNG \& LPG \\
\hline Clean Vehicle Systems & Staten Island & $\mathrm{CNG}$ & $\begin{array}{l}\text { NY Department of } \\
\text { Environmental Protection }\end{array}$ & Corona & $\mathrm{CNG}$ \\
\hline $\begin{array}{l}\text { Consolidated Edison Co. of } \\
\text { N.Y. Inc. }\end{array}$ & Long Island City & CNG & $\begin{array}{l}\text { National Fuel Systems, } \\
\text { Inc. }\end{array}$ & Deer Park & CNG \& LPG \\
\hline Dryden Central School & Dryden & CNG & $\begin{array}{l}\text { New York State Electric } \\
\text { and Gas }\end{array}$ & Bingington & CNG \\
\hline $\begin{array}{l}\text { EDO Corporation } \\
\text { Government System Division }\end{array}$ & College Point & CNG & $\begin{array}{l}\text { Niagara Mohawk Power } \\
\text { Company }\end{array}$ & Albany & LPG \\
\hline Finger Lakes Ambulance & Clifton Springs & LPG & $\begin{array}{l}\text { Synergy Gas Corporation } \\
\text { Conversion Center }\end{array}$ & Farmingdale & LPG \\
\hline
\end{tabular}


Table F1. Companies Performing Conversions by State (Continued)

\begin{tabular}{c|c|c|c|c|c|c|}
\hline Company Name & City & Fuel Type & Company Name & City & Fuel Type \\
\hline
\end{tabular}

NEW YORK (Continued)

\begin{tabular}{lllll}
$\begin{array}{l}\text { Hutchins Carb and } \\
\text { Automotive }\end{array}$ & Binghamton & CNG & Tonawanda Truck Repair & Kenmore \\
$\begin{array}{l}\text { Long Island Lighting } \\
\text { Company }\end{array}$ & Hauppage & CNG & Tower Ford, Inc. & Great Neck \\
\begin{tabular}{l} 
Main Tire Exchange \\
\hline
\end{tabular} & Dansville & CNG \& LPG & & \\
\hline
\end{tabular}

\section{NORTH CAROLINA}

$\begin{array}{llllll}\text { EV Development } & \text { Monroe } & \text { Electric } & \text { Suburban Propane } & \text { Charlotte } & \text { LPG } \\ \text { Piedmont Natural Gas } & \text { Charlotte } & \text { CNG } & \text { Tarheel Energy Corp. } & \text { Raleigh } & \text { CNG }\end{array}$

\section{NORTH DAKOTA}

\begin{tabular}{llllll} 
Alken Auto & Minot & CNG & $\begin{array}{l}\text { Montana-Dakota Utilities } \\
\text { Co. }\end{array}$ & Bismarck & CNG \\
Car Clinic & Williston & CNG & Northland Performance & Bismark & CNG \\
Farstead Oil & Minot & LPG & Suburban Propane & Fargo & LPG \\
George Miller Repair & Minot & CNG & Vision Energy & Bismark & LPG \\
Mel Roth Oil Company, Inc. & Hazen & LPG & & & \\
\hline
\end{tabular}

\section{OHIO}

\begin{tabular}{|c|c|c|c|c|c|}
\hline America's Body Company & Cleveland & CNG \& LPG & $\begin{array}{l}\text { Great Lakes Truck } \\
\text { Equipment }\end{array}$ & Columbus & CNG \\
\hline America's Body Company & Columbus & CNG \& LPG & $\begin{array}{l}\text { Great Lakes Truck } \\
\text { Equipment }\end{array}$ & $\begin{array}{l}\text { Oakwood } \\
\text { Village }\end{array}$ & CNG \\
\hline Cincinnati Gas \& Electric Co. & Cincinatti & CNG \& LPG & $\begin{array}{l}\text { Greater Cincinnati } \\
\text { Conversion Center }\end{array}$ & Melford & $\mathrm{CNG}$ \\
\hline $\begin{array}{l}\text { Columbia Gas Distribution } \\
\text { Company }\end{array}$ & Columbus & $\mathrm{CNG}$ & ITE Services & Columbia & $\mathrm{CNG}$ \\
\hline Crown Division & Lorin & $\mathrm{CNG}$ & LP Propane & Cleveland & CNG \& LPG \\
\hline $\begin{array}{l}\text { Environmentally Safe } \\
\text { Technologies }\end{array}$ & Columbus & $\mathrm{CNG}$ & MetroPane, Inc. & Columbus & CNG \& LPG \\
\hline Evans Propane Service & Ironton & LPG & NESC, Williams Inc. & Zanesville & CNG \\
\hline George E. Kuhn \& Co. & Germantown & LPG & $\begin{array}{l}\text { Reliance Propane } \\
\text { Company }\end{array}$ & Toledo & CNG \& LPG \\
\hline
\end{tabular}

\section{OKLAHOMA}

\begin{tabular}{|c|c|c|c|c|c|}
\hline Air Quip Environmental, Inc. & Tulsa & CNG & & Fry's Propane & Claremore \\
\hline $\begin{array}{l}\text { Alternate Fuel Specialists, } \\
\text { Inc. }\end{array}$ & Oklahoma City & CNG & & Gaines Propane Co. & Okmulgee \\
\hline AmeriGas & Oklahoma City & LPG & & Jerry's Auto Shop & Ponca City \\
\hline AmeriGas Propane & Tulsa & LPG & & Kenny's & Ada \\
\hline American Fuel Conversion & Claremore & CNG & 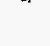 & Kilhaufer's & Canute \\
\hline American Propane Gas Co. & Oklahoma City & LPG & & McClure's Fuel Service & Konewa \\
\hline Beck \& Root Fuel Co. & Arnett & LPG & & Oklahoma Liquified Gas & Chickasha \\
\hline Beck \& Root Fuel Co. & Canute & LPG & & Oklahoma Liquified Gas & Lexington \\
\hline
\end{tabular}




\begin{tabular}{|c|c|c|c|c|c|}
\hline Company Name & City & Fuel Type & Company Name & City & Fuel Type \\
\hline \multicolumn{6}{|c|}{ OKLAHOMA (Continued) } \\
\hline Beck \& Root Fuel Co. & Cheyenne & LPG & Oklahoma Liquified Gas & $\begin{array}{l}\text { Oklahoma } \\
\text { City }\end{array}$ & LPG \\
\hline Beck \& Root Fuel Co. & Eakly & LPG & Oklahoma Liquified Gas & Seminole & LPG \\
\hline Beck \& Root Fuel Co. & Elk City & LPG & Oklahoma Liquified Gas & Tuttle & LPG \\
\hline Beck \& Root Fuel Co. & Roosevelt & LPG & $\begin{array}{l}\text { Oklahoma Natural Gas } \\
\text { Co. }\end{array}$ & Tulsa & CNG \\
\hline Beck \& Root Fuel Co. & Woodward & LPG & Pioneer Clean Fuels, Inc. & Ponca City & CNG \\
\hline Brisco LP Gas & Mustang & LPG & Propane Service Inc. & Shawnee & LPG \\
\hline Brisco LP Gas & Okalhoma City & LPG & Ralston Motor Service & Ralston & LPG \\
\hline Brisco LP Gas & Tutle & LPG & Rural Gas & Ada & LPG \\
\hline Choctaw Propane & Choctaw & LPG & Sales Equipment & $\begin{array}{l}\text { Oklahoma } \\
\text { City }\end{array}$ & LPG \\
\hline $\begin{array}{l}\text { City Spring Natural Gas } \\
\text { Conversion Center }\end{array}$ & Okalhoma City & CNG & $\begin{array}{l}\text { Southwest Gas } \\
\text { Equipment Co., Inc. }\end{array}$ & Buffalo & LPG \\
\hline City Spring Works, Inc. & Oklahoma City & $\mathrm{CNG}$ & Synergy Gas Corporation & Duncan & LPG \\
\hline Clark's & Ada & LPG & $\begin{array}{l}\text { Tex-T Liquid Gas Co., } \\
\text { Inc. }\end{array}$ & Pauls Valley & LPG \\
\hline Clark's & Duncan & LPG & Throop Propane & Ponca City & LPG \\
\hline Coal County Propane & Colgate & LPG & $\begin{array}{l}\text { Tom Gorman Company, } \\
\text { Inc. }\end{array}$ & Tulsa & CNG \& LPG \\
\hline Crane Carrier Company & Tulsa & $\mathrm{CNG}$ & Tri-Fuels & Edmond & CNG \\
\hline $\begin{array}{l}\text { Darr Equipment Co./Darr } \\
\text { Lift Division }\end{array}$ & Tulsa & CNG \& LPG & $\begin{array}{l}\text { Tulsa Gas Technologies, } \\
\text { Inc. }\end{array}$ & Tulsa & CNG \\
\hline Darr Lift of Oklahoma & Oklahoma City & LPG & $\begin{array}{l}\text { United Environmental } \\
\text { Inc. }\end{array}$ & $\begin{array}{l}\text { Oklahoma } \\
\text { City }\end{array}$ & NG \& LPG \\
\hline Dave's Propane & Choctaw & LPG & Watonga Butane, Inc. & Watonga & LPG \\
\hline $\begin{array}{l}\text { Environmental Fuels } \\
\text { Technologies }\end{array}$ & Tulsa & CNG & $\begin{array}{l}\text { Wendell Harrold } \\
\text { Company, The (Tulsa } \\
\text { Facility) }\end{array}$ & Oologah & CNG \\
\hline
\end{tabular}

\section{OREGON}

E-Motion

McMinnville

Electric

Portland Public Schools

Portland

LPG

\section{PENNSYLVANIA}

\begin{tabular}{|c|c|c|c|c|c|}
\hline America's Body Company & Mantico & CNG \& LPG & $\begin{array}{l}\text { National Fuel Gas } \\
\text { Distribution }\end{array}$ & Erie & CNG \\
\hline Beatty's Gas & Home & LPG & Natural Gas 2000, Inc. & Cabot & CNG \& LPG \\
\hline $\begin{array}{l}\text { CNG Services of Pittsburgh, } \\
\text { Inc. }\end{array}$ & Pittsburgh & CNG \& LNG & $\begin{array}{l}\text { Pardee Advanced Fuels, } \\
\text { Inc. }\end{array}$ & Philadelphia & CNG \\
\hline Champagne Imports & Lansdale & CNG & $\begin{array}{l}\text { Peoples Natural Gas } \\
\text { Company }\end{array}$ & Wilkinsburg & CNG \\
\hline Checkeye LPG Carburation & Springdale & CNG \& LPG & Philadelphia Gas Works & Philadelphia & CNG \\
\hline $\begin{array}{l}\text { Consolidated Natural Gas } \\
\text { Co. }\end{array}$ & & CNG & Phoenix Truck Equipment & Nanticoke & $\mathrm{CNG}$ \\
\hline $\begin{array}{l}\text { Environmental Fuels } \\
\text { Corporation }\end{array}$ & Pittsburgh & $\mathrm{CNG}$ & Sabre Equipment & $\begin{array}{l}\text { McKees } \\
\text { Rocks }\end{array}$ & CNG \\
\hline GassWagen Inc. & Anville & CNG & Ten Detroit Diesel & Philadelphia & CNG \\
\hline $\begin{array}{l}\text { Great Lakes Truck } \\
\text { Equipment }\end{array}$ & Nanpicoke & CNG & Torchiano Automotive & $\begin{array}{l}\text { West } \\
\text { Chester }\end{array}$ & CNG \& LPG \\
\hline
\end{tabular}


Table F1. Companies Performing Conversions by State (Continued)

\begin{tabular}{l|l|l|l|l|l|l}
\hline Company Name & City & Fuel Type & Company Name & City & Fuel Type \\
\hline
\end{tabular}

PENNSYLVANIA (Continued)

\begin{tabular}{|c|c|c|c|c|c|}
\hline Kress Service Center & Etna & NG & Zoresco Equipment & Turtle Creek & CNG \\
\hline \multicolumn{6}{|c|}{ RHODE ISLAND } \\
\hline Alternate Energy Corporation & Providence & CNG & Providence Gas Company & Providence & $\mathrm{CNG}$ \\
\hline Miller's Truck Repair, Inc. & Lincoln & LPG & Valley Gas Company & Cumberland & CNG \& LPG \\
\hline \multicolumn{6}{|c|}{ SOUTH CAROLINA } \\
\hline $\begin{array}{l}\text { South Carolina Electric and } \\
\text { Gas Company }\end{array}$ & $\begin{array}{l}\text { Charleston } \\
\text { Heights }\end{array}$ & $\mathrm{CNG}$ & $\begin{array}{l}\text { South Carolina Electric } \\
\text { and Gas Company }\end{array}$ & Columbia & CNG \\
\hline \multicolumn{6}{|c|}{ SOUTH DAKOTA } \\
\hline Arrow Automotive & Black Hawk & $\mathrm{CNG}$ & Gales Gas Service & Pierre & LPG \\
\hline Brick Propane, Inc. & Aberdeen & LPG & Lemmon Propane Inc. & Lemmon & LPG \\
\hline Dodge Town, Inc. & Rapid City & CNG & McKie Ford & Rapid City & $\mathrm{CNG}$ \\
\hline
\end{tabular}

\section{TENNESSEE}

\begin{tabular}{llllll} 
AmeriGas & Memphis & LPG & NU-KAR Electric Vehicles & Collierville & Electric \\
CH 4 Technologies, Inc. & Collierville & CNG & Nashville Gas & Nashville & CNG \\
Covington Gas Company & Covington & CNG & Suburban Propane & Clarksville & LPG \\
Covington Gas Company & Covington & CNG & Suburban Propane & Jackson & LPG \\
Gibson Propane Inc. & Memphis & LPG & Suburban Propane & Nashville & LPG \\
\hline
\end{tabular}

TEXAS

Abilene AG Ford New

Holland, Inc.

Acme LP Gas

Action Handling Systems

Action Propane

Adkins Oil Co

Akin Propane

Allen Forklift, Inc.

Alternate Fuel Conversions

Alternative Fuel Conversions

Alternative Fuels

Alternative Fuels

Conversions

AmeriGas Propane Inc.

AmeriGas Propane Inc.

American Industrial Trucks

American Natural Gas

Power, Inc.

Amisted Propane

Appelt Propane

Askins

Associated Supply Co., Inc.

$\begin{array}{ll}\text { Abilene } & \text { LPG } \\ \text { George West } & \text { LPG } \\ \text { Houston } & \text { LPG } \\ \text { Leander } & \text { LPG } \\ \text { Crowell } & \text { LPG } \\ \text { Stockdale } & \text { LPG } \\ \text { Sherman } & \text { LPG } \\ \text { Caldwell } & \text { LPG } \\ \text { Clifton } & \text { NG \& LPG } \\ \text { Austin } & \text { NG } \\ \text { Converse } & \text { CNG \& LPG } \\ \text { Alvin } & \text { LPG } \\ \text { Wylie } & \text { LPG } \\ \text { Harlingen } & \text { LPG } \\ \text { Houston } & \text { CNG \& LNG } \\ \text { Del Rio } & \text { LPG } \\ \text { Three Rivers } & \text { LPG } \\ \text { Robert Lee } & \text { LPG } \\ \text { Amarillo } & \text { LPG }\end{array}$

J \& L Propane

Krum

LPG

J.V. Equipment Co., Inc.

Edinburg

LPG

JTR Sales \& Service

Lufkin

Jettgas

Jim Black Oil Co.

Laredo

LPG

Hart

John L. Rust Company

EI Paso

John Witt Butane Gas Co.

Johnson Butane

Tahoka

LPG

K-D Manitou, Inc.

Hamlin

LPG

K.C. Sales Co.

Waco

LPG

Kamp Supply Co.

San Angelo

L.PG

Hereford

LPG

Kemp Supply Company

Hereford

LPG

Kennedy Butane Inc.

Coleman

LPG

Kirksey Propane Service,

Lockhart

LPG Inc.

LP Gas Co.

Nocona

LPG

Lamesa Butane Co.

Lamesa

LPG

Liquigas, Inc.

Lufkin

LPG

Liquilux

Houston

LPG

Littlefield Butane Co.

LPG 
Table F1. Companies Performing Conversions by State (Continued)

\begin{tabular}{l|l|l|l|l|l|l|l}
\hline Company Name & City & Fuel Type & Company Name & City & Fuel Type \\
\hline
\end{tabular}

TEXAS (Continued)

\begin{tabular}{|c|c|c|c|c|c|}
\hline Atmos Energy & Dallas & NG & Lockney Butane Co. & Lockney & LPG \\
\hline Automatic L.P. Gas Co. & Conroe & LPG & Lone Star Propane Co. & Harlingen & LPG \\
\hline Ayres Oil Co. & Holliday & LPG & Lytle Propane & Lytle & LPG \\
\hline Ayres Oil Inc. & Vernon & LPG & MESA Environmental & Fort Worth & CNG \\
\hline B \& B Fuel Co., Inc. & Seminole & LPG & MF Automotive & Amarillo & LPG \\
\hline BMS & Pearland & LPG & Martin LP Gas & Kilgore & LPG \\
\hline Barbour Brothers & Tulia & LPG & Martin Racing Supply & Fritch & LPG \\
\hline Bay Gas Inc. & League City & LPG & $\begin{array}{l}\text { Mathis Reynolds Sales } \\
\text { Co. }\end{array}$ & Mathis & LPG \\
\hline $\begin{array}{l}\text { Best Material \& Handling, } \\
\text { Inc. }\end{array}$ & Houston & LPG & Matlock & $\begin{array}{l}\text { Colorado } \\
\text { City }\end{array}$ & LPG \\
\hline Bethel Oil Co. & Snyder & LPG & McCormick & Snyder & LPG \\
\hline Birdsong Automotive & Beaumont & LPG & $\begin{array}{l}\text { Medley Material } \\
\text { Handling, Inc. }\end{array}$ & Amarillo & LPG \\
\hline Birdsong Peanuts & Gorman & LPG & $\begin{array}{l}\text { Medley Material } \\
\text { Handling, Inc. }\end{array}$ & El Paso & LPG \\
\hline Bob's LP Gas, Inc. & Early & LPG & Midland 66 Oil Co., Inc. & Midland & LPG \\
\hline Bowie Butane Gas Co & Bowie & LPG & Midtex LP Gas & Midlothian & LPG \\
\hline Boyd's Equipment & Amarillo & LPG & Mission Gas Company & San Antonio & LPG \\
\hline Brady Butane Co & Brady & LPG & Mitchell Butane Gas Sales & Arlington & LPG \\
\hline Brigg-Weaver, Inc. & Freeport & LPG & $\begin{array}{l}\text { Mitchell Energy } \\
\text { Corporation }\end{array}$ & Bridgeport & LPG \\
\hline Briggs-Weaver, Inc. & Beaumont & LPG & $\begin{array}{l}\text { Mitchell Energy } \\
\text { Corporation }\end{array}$ & Fort Worth & LPG \\
\hline Briggs-Weaver, Inc. & Fort Worth & LPG & $\begin{array}{l}\text { Mitchell Energy } \\
\text { Corporation }\end{array}$ & $\begin{array}{l}\text { The } \\
\text { Woodlands }\end{array}$ & LPG \\
\hline Briggs-Weaver, Inc. & San Antonio & LPG & $\begin{array}{l}\text { Modern Diversified } \\
\text { Propane Services }\end{array}$ & Austin & LPG \\
\hline Busters Butane Gas Co., Inc. & Corpus Cristi & LPG & $\begin{array}{l}\text { Murray \& Massie Butane } \\
\text { Co }\end{array}$ & Byers & LPG \\
\hline Butane Gas \& Appliance Co. & Robstown & LPG & NGV Technology Center & El Paso & NG \\
\hline C Clark Propane & Pampa & LPG & Nelson Putman Propane & Corsicana & LPG \\
\hline $\begin{array}{l}\text { CIM Industrial Machinery, } \\
\text { Inc. }\end{array}$ & Houston & CNG \& LPG & Nichols LP Gas Service & Clifton & LPG \\
\hline $\begin{array}{l}\text { Callaway's Propane and } \\
\text { Automotive Service }\end{array}$ & Lubbock & LPG & $\begin{array}{l}\text { Northwest Butane Gas } \\
\text { Company }\end{array}$ & Dallas & LPG \\
\hline Calvin Gas Co. & Wichita Falls & LPG & $\begin{array}{l}\text { Omni Material Handling, } \\
\text { Inc. }\end{array}$ & Austin & LPG \\
\hline Cannon's LP Gas Co. & Hamphill & LPG & Ozona Butane Co. & Sanderson & LPG \\
\hline Carb. Equipment of El Paso & El Paso & LPG & $\begin{array}{l}\text { Palestine Welding \& } \\
\text { Indus Supply }\end{array}$ & Palestine & LPG \\
\hline Carruth-Doggett, Inc. & Houston & LPG & $\begin{array}{l}\text { Panhandle Forklift \& } \\
\text { Equipment }\end{array}$ & Amarillo & LPG \\
\hline Cass County Butane Co. & Linden & LPG & $\begin{array}{l}\text { Panhandle Forklift \& } \\
\text { Equipment, Inc. }\end{array}$ & Lubbock & LPG \\
\hline Centex Butane & Georgetown & LPG & Parker Power Systems & Dallas & LPG \\
\hline Central Texas Clarklift & Austin & LPG & Peace, Bill, \& Son, Inc. & San Antonio & LPG \\
\hline Central Texas Clarklift & Waco & LPG & Penman Conoco Service & Knox City & LPG \\
\hline
\end{tabular}




\begin{tabular}{|c|c|c|c|c|c|}
\hline Company Name & City & Fuel Type & Company Name & City & Fuel Type \\
\hline \multicolumn{6}{|c|}{ TEXAS (Continued) } \\
\hline $\begin{array}{l}\text { Central Texas Energy } \\
\text { Suppliers }\end{array}$ & Comanche & LPG & Penman Propane, Inc. & Rochester & LPG \\
\hline Chadwell \& Son Gas Co. & Springtown & LPG & Perryman Propane & Houston & LPG \\
\hline Champagne Fuels & Houston & CNG \& LPG & Petty Butane Co. & Vernon & LPG \\
\hline Chico Butane Gas Co. & Chico & LPG & $\begin{array}{l}\text { Precision General, Inc. } \\
\text { Algas CA }\end{array}$ & Houston & LPG \\
\hline City Bottle Gas & Cleveland & LPG & Progas & Vidor & LPG \\
\hline Clarklift of El Paso, Inc. & El Paso & LPG & Progas Energy Services & Freeport & LPG \\
\hline Coastal Butane Service Co. & Rosenberg & LPG & $\begin{array}{l}\text { Propane Equipment } \\
\text { Company }\end{array}$ & Houston & LPG \\
\hline Coleman Butane Gas Co & Coleman & LPG & Propane Systems & Fort Worth & LPG \\
\hline Concho Butane Co. & San Angelo & LPG & R \& W Supply, Inc. & Amarillo & CNG \& LPG \\
\hline Cooper Butane Co. & Paris & LPG & R \& W Supply, Inc. & Littlefield & CNG \& LPG \\
\hline Country Boys Feed \& Supply & Rocksprings & LPG & $\begin{array}{l}\text { Rath Propane Gas C. dba } \\
\text { Cuero Propane Gas }\end{array}$ & Cuero & LPG \\
\hline Crittendon Butane Co., Inc. & Bonham & LPG & $\begin{array}{l}\text { Recreational Vehicle } \\
\text { Service, Corp. }\end{array}$ & Beaumont & LPG \\
\hline $\begin{array}{l}\text { Crosby County Fuel } \\
\text { Association }\end{array}$ & Ralls & LPG & Reliable Gas Co. & Tyler & LPG \\
\hline Crosby Mechanical Services & Houston & LPG & Replica Roadsters & Waco & Electric \\
\hline Cuero Propane Gas Co & Cuero & LPG & Roadrunner Energy, Inc. & Uvalde & LPG \\
\hline $\begin{array}{l}\text { Cummins Southern Plains, } \\
\text { Inc. }\end{array}$ & Mesquite & NG & Rocking B Auto \& Fuel & Bushland & LPG \\
\hline Cypert Butane Co. & Garden City & LPG & Sands Propane Inc. & Granbury & LPG \\
\hline Cypert Garage Co. & Garden City & LPG & Sands Propane Inc. & Weatherford & LPG \\
\hline $\begin{array}{l}\text { D G \& F Propane \& } \\
\text { Conversions }\end{array}$ & El Paso & LPG & $\begin{array}{l}\text { Schneider Distributing } \\
\text { Co. }\end{array}$ & San Angelo & NA \\
\hline DFW Electric Vehicles & Lewisville & Electric & Schooling LP Gas & Decatur & LPG \\
\hline Dale Ross \& Sons & Hawley & LPG & Scott Fuel Inc. & Sweetwater & LPG \\
\hline Dan's Furniture \& Butane & Cotulla & LPG & Seminole Butane Co. & Seminole & LPG \\
\hline Darr Equipment Co. & Dallas & LPG \& EV & Servigas & El Paso & LPG \\
\hline Darr Equipment Co. & Fort Worth & LPG \& EV & Servigas & El Paso & LPG \\
\hline Darr Equipment Co. & Irving & LPG & Sewalt Butane Company & Brownwood & LPG \\
\hline Darr Equipment Co. & Longview & CNG \& LPG & Sharp Propane & Austin & LPG \\
\hline Darr Equipment Co. & Nash & LPG & Sharp Propane & Bastrop & LPG \\
\hline Darr Equipment Co. & Tyler & LPG & Sharp Propane & Conroe & LPG \\
\hline Darr Equipment Co. & Waco & LPG & Sharp Propane & La Grange & LPG \\
\hline Darr Equipment Co. & Wichita Falls & LPG & Sharp Propane & Onalaska & LPG \\
\hline Dartech Automotive & Garland & LPG & Sharp Propane & Seguin & LPG \\
\hline Deo Sharp Propane & La Grange & LPG & Shelby LP Gas Co & Mt. Bellvue & LPG \\
\hline Dixie LP Gas & Hillsboro & LPG & Shelby LP Gas Co., Inc. & Center & LPG \\
\hline Dobbs-Weir Co & Childress & LPG & Shelton Butane Co. & $\begin{array}{l}\text { Sulphur } \\
\text { Springs }\end{array}$ & LPG \\
\hline Don's Butane Service & Graham & LPG & Shelton Oil \& Gas Co. & Mertzon & LPG \\
\hline Don's Butane Service & Loving & LPG & $\begin{array}{l}\text { Shoppa's Material } \\
\text { Handling, Inc. }\end{array}$ & Arlington & LPG \\
\hline
\end{tabular}




\begin{tabular}{|c|c|c|c|c|c|}
\hline Company Name & City & Fuel Type & Company Name & City & Fuel Type \\
\hline \multicolumn{6}{|c|}{ TEXAS (Continued) } \\
\hline $\begin{array}{l}\text { Doyle's Garage \& LP } \\
\text { Conversion }\end{array}$ & Shallowater & LPG & Sierra Gas Products, Inc. & Alpine & LPG \\
\hline Eagle-Picher Industries, Inc. & Lubbock & LPG & Signal Fuels Co. & Pampa & LPG \\
\hline $\begin{array}{l}\text { Earnest Automotive \& Delco } \\
\text { Tech Center }\end{array}$ & Abilene & CNG \& LPG & Silvers Butane Co. & Morton & LPG \\
\hline $\begin{array}{l}\text { Earnest Automotive \& } \\
\text { Delco-Tech Service Center }\end{array}$ & Abilene & NG \& LPG & Silverton Oil Co. & Silverton & LPG \\
\hline East Texas Clarklift, Inc. & Longview & LPG & Skelly Propane & Pampa & LPG \\
\hline East Texas Lift Trucks, Inc. & Tyler & LPG & $\begin{array}{l}\text { Slaton Gas \& Equipment } \\
\text { Co., Inc. }\end{array}$ & Slaton & LPG \\
\hline Eddie's Garage & Needville & LPG & Slot Car Mustangs & Houston & CNG \\
\hline Eddins-Walcher Co. & Brownfield & LPG & $\begin{array}{l}\text { Smith \& Smith Propane } \\
\text { Service }\end{array}$ & Killeen & LPG \\
\hline Eddins-Walcher Co. & Del Rio & LPG & Smith's Propane Service & Perryton & LPG \\
\hline Eddins-Walcher Co. & Lubbock & LPG & $\begin{array}{l}\text { Southern Union } \\
\text { Econofuel Company }\end{array}$ & Austin & CNG \\
\hline Eddins-Walcher Co. & Odessa & LPG & $\begin{array}{l}\text { Southern Union } \\
\text { Econofuel Company }\end{array}$ & El Paso & CNG \& LPG \\
\hline Eddins-Walcher Co. & Seminole & LPG & Southern Union Gas & Austin & CNG \& LNG \\
\hline Eddins-Walcher Co. & Sonora & LPG & Southern Union Gas & El Paso & CNG \& LNG \\
\hline Electric Motor Cars & Houston & Electric & Southline Equipment Co. & Beaumont & LPG \\
\hline Electrickar & Dallas & Electric & Southline Equipment Co. & Freeport & LPG \\
\hline Ellen Equipment Corp. & El Paso & LPG & Southwest Lift & Laredo & LPG \\
\hline Empiregas of Canton & Canton & LPG & $\begin{array}{l}\text { Southwest Lift Truck } \\
\text { Company }\end{array}$ & $\begin{array}{l}\text { Corpus } \\
\text { Christi }\end{array}$ & LPG \\
\hline Empiregas of Kemp & Kemp & LPG & $\begin{array}{l}\text { Southwest Lift Truck } \\
\text { Company }\end{array}$ & Laredo & LPG \\
\hline Empiregas of Orange County & Orange & LPG & $\begin{array}{l}\text { Southwest Lift Truck } \\
\text { Company }\end{array}$ & Pharr & LPG \\
\hline Empiregas of Paducah & Paducah & LPG & Southwest Marketers & Monahans & LPG \\
\hline Empiregas of Waco & Waco & IPG & Spice Energy & Fort Worth & CNG \& LPG \\
\hline Empyrium, Inc. & San Antonio & Electric & Star Tex Propane & Waco & LPG \\
\hline Enderby Gas, Inc. & Duncanville & LPG & $\begin{array}{l}\text { Stewart \& Stevenson } \\
\text { Services }\end{array}$ & Houston & NG \& LPG \\
\hline Enderby Gas, Inc. & Gainesville & LPG & Stix Gas Co. & Sinton & LPG \\
\hline Enderby Gas, Inc. & Temple & LPG & Stratford Butane & Stratford & LPG \\
\hline Enderli Trucking Corporation & Baytown & LPG & Suburban Propane & Austin & LPG \\
\hline EnerGas & Lubbock & CNG & Suburban Propane & Austin & LPG \\
\hline Enfuels Corporation & Houston & CNG & Suburban Propane & Denton & LPG \\
\hline Entex & Houston & $\mathrm{CNG}$ & Suburban Propane & McKinney & LPG \\
\hline ExproFuels & Dallas & NG \& LPG & Suburban Propane & $\begin{array}{l}\text { Sulphur } \\
\text { Springs }\end{array}$ & LPG \\
\hline ExproFuels & San Antonio & NG \& LPG & Sun City Beverage, Inc. & El Paso & LPG \\
\hline F \& W Supply & Amarillo & LPG & Tarkington Propane & Cleveland & LPG \\
\hline Farmers Propane Gas Co. & Hamilton & LPG & Texas A\&M University & $\begin{array}{l}\text { College } \\
\text { Station }\end{array}$ & LPG \\
\hline Federal Petroleum Co & Brownsville & LPG & Texas Alternative Fuels & Tyler & NG \& LPG \\
\hline Federal Petroleum Co. & Harlingen & LPG & Texas Propane & Rockdale & LPG \\
\hline
\end{tabular}


Table F1. Companies Performing Conversions by State (Continued)

\begin{tabular}{l|l|l|l|l|l|l|l}
\hline Company Name & City & Fuel Type & Company Name & City & Fuel Type \\
\hline
\end{tabular}

TEXAS (Continued)

\begin{tabular}{|c|c|c|c|c|c|}
\hline Federal Petroleum Co. & Weslaco & LPG & Texline Oil \& Gas Co. & Texline & LPG \\
\hline Ferellgas & San Antonio & LPG & Thermagas & Bowie & LPG \\
\hline Ferrellgas & Houston & LPG & Thomas Propane Co & DeLeon & LPG \\
\hline Fieldton Butane \& Fertilizer & Fieldton & LPG & Tipton Oil \& Butane & Floydada & LPG \\
\hline Five Fuels Conversions & Conroe & NG, LPG, M85 & Toyalift of El Paso, Inc. & El Paso & LPG \& EV \\
\hline Five Fuels Conversions & Shreveport & $\mathrm{CNG}$ & $\begin{array}{l}\text { Transtar Technologies, } \\
\text { L.C. }\end{array}$ & Dallas & $\mathrm{CNG}$ \\
\hline Fleet Propane & Houston & LPG & $\begin{array}{l}\text { Transtexas Gas } \\
\text { Corporation }\end{array}$ & Laredo & LPG \\
\hline Fletcher Service Co. & Eagle Pass & LPG & $\begin{array}{l}\text { Transtexas Gas } \\
\text { Corporation }\end{array}$ & Laredo & LPG \\
\hline Flores Gas Co. & El Paso & LPG & Tri Tex Energy Co & Cisco & LPG \\
\hline $\begin{array}{l}\text { Flowers Pontiac-Cadillac } \\
\text { Company }\end{array}$ & Galveston & CNG \& LPG & Tri-Co Propane & Rogers & LPG \\
\hline $\begin{array}{l}\text { Forklift Service Co. of } \\
\text { Houston }\end{array}$ & Houston & LPG & Trio Fuels & Big Spring & LPG \\
\hline Fraley Butane Co. & Abilene & LPG & Tucker Oil Co. & Slaton & LPG \\
\hline Frank's Fuels, Inc. & Odessa & LPG & $\begin{array}{l}\text { Turner Automotive LP } \\
\text { Gas Service }\end{array}$ & Clifton & LPG \\
\hline Fred Garrison Oil Co. & Plainview & LPG & $\begin{array}{l}\text { Tyler Fuel Injection } \\
\text { Service, Inc. }\end{array}$ & Tyler & NG \& LPG \\
\hline Fricks Butane Gas & Texarkana & LPG & V Bell Oil Co.- LPG & Pampa & LPG \\
\hline Gainer, Glenn H. \& Sons, Inc. & Dallas & LPG & Van's Garage & $\begin{array}{l}\text { Corpus } \\
\text { Christi }\end{array}$ & CNG \& LPG \\
\hline Gainesville Fuel & Gainesville & LPG & $\begin{array}{l}\text { Vinyard Engine Systems, } \\
\text { Inc. }\end{array}$ & San Antonio & NG \& LPG \\
\hline Gangl's Custom Auto & Taylor & LPG & Vista Oil Co. & McAllen & LPG \\
\hline Gilbert Gas Co. & Livingston & LPG & Wagner \& Brown & Sterling City & CNG \\
\hline Glenn Martin Propane & Spur & LPG & Walker Automotive & & LPG \\
\hline Godfrey Butane Co & Arlington & LPG & $\begin{array}{l}\text { Wallace Environmental } \\
\text { Testing Lab Inc. }\end{array}$ & Houston & NG \& LPG \\
\hline Grady Walker L.P. Gas Co & Big Spring & LPG & Walters Equipment, Inc. & Waco & LPG \\
\hline $\begin{array}{l}\text { Green's Blue Flame Gas Co., } \\
\text { Inc. }\end{array}$ & Houston & CNG \& LPG & $\begin{array}{l}\text { Waukesha-Pearce } \\
\text { Industries, Inc. }\end{array}$ & Irving & NG \& LPG \\
\hline Griffin Butane Co. & Odessa & LPG & $\begin{array}{l}\text { Waukesha-Pearce } \\
\text { Industries, Inc. }\end{array}$ & Kilgore & NG \& LPG \\
\hline Griffin Propane Co. & Eldorado & LPG & Wayne's Garage & Devine & LPG \\
\hline H.W. Lemens & Merkel & LPG & Welch Gas & Linden & LPG \\
\hline H.W. Lemens LPG & Abilene & LPG & WelchGas-Clarksville & Clarksville & LPG \\
\hline Haigood \& Campbell & Archer City & LPG & WelchGas-Mt Pleasant & Mt Pleasant & LPG \\
\hline Haigood \& Campbell & Wichita Falls & LPG & WelchGas-Naples & Naples & LPG \\
\hline Hall Propane Co. & Port Lavaca & LPG & Werley's Forklift Service & Garland & LPG \\
\hline Halpert LPG & ElDorado & LPG & West Texas Gas & Crane & LPG \\
\hline Hardy's Garage & Nacogdoches & LPG & West Texas Gas & Pecos & LPG \\
\hline Harrell's Forklift Service & Fort Worth & LPG & $\begin{array}{l}\text { West Tx. Transp. } \\
\text { Conversion, Inc. }\end{array}$ & El Paso & LPG \\
\hline Haskell Butane Co. & Haskell & LPG & $\begin{array}{l}\text { Western Clarklift \& } \\
\text { Supply, Inc. }\end{array}$ & Lubbock & LPG \\
\hline
\end{tabular}




\begin{tabular}{l|l|l|l|l|l|l|l}
\hline Company Name & City & Fuel Type & Company Name & City & Fuel Type \\
\hline
\end{tabular}

TEXAS (Continued)

\begin{tabular}{|c|c|c|c|c|c|}
\hline Hereford Butane Inc. & Hereford & LPG & $\begin{array}{l}\text { Western Clarklift \& } \\
\text { Supply, Inc. }\end{array}$ & Lubbock & LPG \\
\hline Hino Gas & Harlingen & LPG & $\begin{array}{l}\text { Williams Automotive } \\
\text { Service }\end{array}$ & $\begin{array}{l}\text { Fort } \\
\text { Stockton }\end{array}$ & LPG \\
\hline Hudson Butane Co & Bridgeport & LPG & Williams Oil \& Gas Co. & Memphis & LPG \\
\hline Huffhines Gas, Inc. & Dallas & LPG & Wolfforth LP Gas & Wolfforth & LPG \\
\hline Hughes Propane & Pinehurst & LPG & $\begin{array}{l}\text { Wood County Automatic } \\
\text { Gas Co. }\end{array}$ & Quitman & LPG \\
\hline Hunter Oil \& Propane & Beeville & LPG & World Lift Truck & Hewitt & LPG \\
\hline Hurley Butane \& Oil Co & Bay City & LPG & Wylie LP Gas & Lubbock & LPG \\
\hline Ideal Gas & Levelland & LPG & Wylie LP Gas, Inc. & Petersburg & LPG \\
\hline $\begin{array}{l}\text { Independent Oil Co., dba } \\
\text { Dixie LP Gas }\end{array}$ & Hillsboro & LPG & X Propane Service & Edinburg & LPG \\
\hline $\begin{array}{l}\text { Industrial Lift Rental \& Serv. } \\
\text { Co. }\end{array}$ & Houston & LPG & Young Co. Butane & Graham & LPG \\
\hline
\end{tabular}

UTAH

$\begin{array}{llllll}\text { AmeriGas } & \text { Salt Lake City } & \text { LPG } & \text { Mountain Fuel } & \text { Salt Lake } & \text { CNG } \\ \begin{array}{l}\text { Battery Automated } \\ \text { Transportation (B.A.T.) }\end{array} & \text { West Valley City } & \text { Electric } & \begin{array}{l}\text { Smith Detroit } \\ \text { Diesel-Allison, Inc. }\end{array} & \begin{array}{l}\text { Salt Lake } \\ \text { City }\end{array} & \text { CNG } \\ \begin{array}{l}\text { Commercial Propane Fleet } \\ \text { Services }\end{array} & \text { Salt Lake City } & \text { LPG } & \text { Tesco Williamson } & \text { Salt Lake } & \text { CNG \& LNG } \\ \text { Larry H. Miller Chevrolet } & \text { Murray } & \text { CNG } & & \text { City }\end{array}$

\section{VERMONT}

\begin{tabular}{lllll}
$\begin{array}{l}\text { Savage Auto Care } \\
\text { Vermont Electric Car }\end{array}$ & $\begin{array}{l}\text { North Hyde Park } \\
\text { Middlesex }\end{array}$ & LPG & Vermont Gas Systems & Burlington \\
\hline
\end{tabular}

\section{VIRGINIA}

\begin{tabular}{|c|c|c|c|c|c|}
\hline American Eco Fuel & Chantilly & CNG \& LPG & $\begin{array}{l}\text { G \& M Service Center, } \\
\text { Inc. }\end{array}$ & Lorton & CNG \\
\hline $\begin{array}{l}\text { Baker Equipment } \\
\text { Engineering }\end{array}$ & Richmond & Electric & $\begin{array}{l}\text { Norman's Automotive } \\
\text { Services Inc. }\end{array}$ & Springfield & CNG \& LPG \\
\hline Carburation Labs East, Inc. & Warrenton & NG & Suburban Propane & Onley & LPG \\
\hline Commonwealth Propane, Inc. & Richmond & LPG & Virginia LP Trucks Inc. & Stony Creek & LPG \\
\hline Cryogenic Fuels Inc. & Manassas & LNG & $\begin{array}{l}\text { Washington Gas } \\
\text { Company }\end{array}$ & Springfield & $\mathrm{CNG}$ \\
\hline Enginevity & Virginia Beach & CNG & & & \\
\hline \multicolumn{6}{|c|}{ WASHINGTON } \\
\hline Auburn Chevrolet & Auburn & $\mathrm{CNG}$ & Pierce Transit & Tacoma & CNG \\
\hline Electric Cars Seattle & Seattle & Electric & Suburban Propane & Marysville & LPG \\
\hline Energy Conversions, Inc. & Tacoma & NG & Sunshine Propane & $\begin{array}{l}\text { Port } \\
\text { Townsend }\end{array}$ & LPG \\
\hline Gabriel Marine & Port Ludlow & Electric & Washington Natural Gas & Seattle & CNG \\
\hline Northwest Propane Sales Inc. & Lynden & LPG & Washington Water Power & Spokane & CNG \\
\hline
\end{tabular}


Table F1. Companies Performing Conversions by State (Continued)

\begin{tabular}{|c|c|c|c|c|c|}
\hline Company Name & City & Fuel Type & Company Name & City & Fuel Type \\
\hline \multicolumn{6}{|c|}{ WEST VIRGINIA } \\
\hline $\begin{array}{l}\text { Automotive Research } \\
\text { Technologies }\end{array}$ & Bridgeport & $\mathrm{CNG}$ & Hope Gas Inc. & Clarksburg & $\mathrm{CNG}$ \\
\hline CATCO Trucking Co. & Belle & CNG & Kleenair Systems, Inc. & Martinsburg & CNG \\
\hline $\begin{array}{l}\text { Commercial Truck \& Tractor } \\
\text { Repair, Inc. }\end{array}$ & Nutter Fort & $\mathrm{CNG}$ & $\begin{array}{l}\text { Total Performance Auto } \\
\text { Care Center }\end{array}$ & Huntington & NG \\
\hline
\end{tabular}

\section{WISCONSIN}

\begin{tabular}{|c|c|c|c|c|c|}
\hline American Dual Fuels Inc. & Middleton & LPG & $\begin{array}{l}\text { Motor Propane Service } \\
\text { Inc. }\end{array}$ & Manitowoc & LPG \\
\hline $\begin{array}{l}\text { Automotive Natural Gas, Inc. } \\
\text { (ANGI) }\end{array}$ & Milton & CNG \& LPG & $\begin{array}{l}\text { W.J. Kuhn Automotive } \\
\text { Center }\end{array}$ & Oak Creek & CNG \\
\hline Clarklift of Wisconsin Inc. & Milwaukee & CNG & Walters Gas Serviec Inc. & Beaver Dam & LPG \\
\hline Inland Detroit Diesel, Inc. & Butler & CNG \& LPG & $\begin{array}{l}\text { Wisconsin Fuel \& Light } \\
\text { Co. }\end{array}$ & Wausau & CNG \\
\hline L.P. Gas Equipment & Butler & CNG \& LPG & Wisconsin Gas Company & Milwaukee & $\mathrm{CNG}$ \\
\hline Monroe Truck Equipment & Janesville & CNG \& LPG & $\begin{array}{l}\text { Wisconsin Natural Gas } \\
\text { Company }\end{array}$ & Oakcreek & CNG \\
\hline \multirow[t]{2}{*}{ Monroe Truck Equipment } & Monroe & CNG \& LPG & $\begin{array}{l}\text { Wisconsin Public Service } \\
\text { Corporation }\end{array}$ & Sheboygan & CNG \\
\hline & \multicolumn{3}{|c|}{ WYOMING } & & \\
\hline Bison Oil & Sheridan & LPG & $\begin{array}{l}\text { Farmers Cooperative } \\
\text { Assn. }\end{array}$ & Gillette & LPG \\
\hline $\begin{array}{l}\text { Butane Power \& Equipment } \\
\text { Co. }\end{array}$ & Casper & LPG & Phillips 66 Propane & Laramie & LPG \\
\hline $\begin{array}{l}\text { Butane Power \& Equipment } \\
\text { Co. }\end{array}$ & Powell & LPG & Ron's LP Gas Service & Sheridan & LPG \\
\hline $\begin{array}{l}\text { Butane Power \& Equipment } \\
\text { Co. }\end{array}$ & Rawlins & LPG & & & \\
\hline
\end{tabular}

\section{LOCATION UNKNOWN}

$\begin{array}{lllll}\text { Air Products \& Chemicals, } & - & \text { Methane } & \begin{array}{l}\text { Mapco Natural Gas } \\ \text { Liquids }\end{array} & \text { - } \\ \text { Inc. } & - & \text { LNG } & \text { Suburban Propane } & - \text { - } \\ \begin{array}{l}\text { Cryogas, USA, Inc. } \\ \text { Equipment \& Systems }\end{array} & - & \text { CNG \& LPG } & & \text { LPG } \\ \text { Engineering } & - & & & \end{array}$

Note: LPG = Liquefied Petroleum Gases; $C N G=$ Compressed Natural Gas; NG = Natural Gas; Alc = Alcohol; EV = Electric Vehicle; M85 = mixture of $85 \%$ Methanol, $15 \%$ Gasoline.

Source: Energy Information Administration, Office of Coal, Nuclear, Electric, and Alternate Fuels, " Alternative Fueled Vehicle Contacts Data Base." 
Table F2. Original Equipment Manufacturers by State

\begin{tabular}{l|l|l|l|l|l|l|}
\hline Company Name & City & Fuel & Company Name & City & Fuel \\
\hline
\end{tabular}

ALABAMA

American Ikarus, Inc Annston $\quad$ LNG

\section{ARKANSAS}

\begin{tabular}{|c|c|c|c|c|c|}
\hline AZ Industries & Hardy & \multicolumn{4}{|l|}{ CNG,LPG,EV } \\
\hline \multicolumn{6}{|c|}{ CALIFORNIA } \\
\hline APS Systems & Oxnard & Electric & El Dorado National Co. & Chino & NG \& LPG \\
\hline APS Systems & Santa Barbara & Electric & Gillig Corporation & Ontario & NG, LPG, Alc \\
\hline Badsey Design of California & San Clemente & Electric & Pacific Electric Vehicles & Sacramento & Electric \\
\hline $\begin{array}{l}\text { Battery Automated } \\
\text { Transportation International }\end{array}$ & Burbank & Electric & Pacific PowerCycles, Inc. & Irvine & Electric \\
\hline Burkhardt Turbines & Fort Bragg & Electric & Pro Electric Vehicles & Penn Valley & Electric \\
\hline Bus Manufacturing USA & Goleta & CNG \& Elec & $\begin{array}{l}\text { Specialty Vehicle } \\
\text { Manufacturing Corp. }\end{array}$ & Downey & Electric \\
\hline California Electric Cars Inc. & Seaside & Electric & Sun Toys & Santa Cruz & Electric \\
\hline Clean Air Partners, Inc. & San Diego & CNG & & & \\
\hline
\end{tabular}

\section{FLORIDA}

\begin{tabular}{lllll}
$\begin{array}{l}\text { Conversion Labs } \\
\text { International } \\
\text { Renaissance Cars }\end{array}$ & Miami & NG & Solar Trike and Car & $\begin{array}{l}\text { Big Pine } \\
\text { Key }\end{array}$ \\
\hline
\end{tabular}

\section{GEORGIA}

\begin{tabular}{lllll} 
Blue Bird Corporation & Ft. Valley & NG & Club Car, Inc. & Martinez \\
Blue Bird Corporation & Lafayette & NG & Electric \\
\hline
\end{tabular}

\section{HAWAII}

Suntara

Honokaa

Electric

\section{IOWA}

\begin{tabular}{|c|c|c|c|c|c|}
\hline Blue Bird Corporation & Mt. Pleasant & $N G$ & John Deere \& Co. & Waterloo & CNG \\
\hline \multicolumn{6}{|c|}{ IDAHO } \\
\hline MK Rail Corporation & Boise & LNG & & & \\
\hline \multicolumn{6}{|c|}{ ILLINOIS } \\
\hline Caterpillar & Mossville & CNG \& LPG & Navistar International & $\begin{array}{l}\text { Melrose } \\
\text { Park }\end{array}$ & CNG \\
\hline $\begin{array}{l}\text { Century Alternate Fuel } \\
\text { Systems }\end{array}$ & Chicago & LPG & Soleq & Chicago & Electric \\
\hline
\end{tabular}

\section{INDIANA}

\begin{tabular}{lllll} 
Carpenter Mfg. & Mitchell & NG Alc Ele & Carpenter Mfg. & Richmond NG,Alc, EV \\
\hline & KANSAS & Saline & NG, LPG, Alc
\end{tabular}


Table F2. Original Equipment Manufacturers (Continued)

\begin{tabular}{|c|c|c|c|c|c|}
\hline Company Name & City & Fuel Type & Company Name & City & Fuel Type \\
\hline \multicolumn{6}{|c|}{ KENTUCKY } \\
\hline Clark Material Handling Co. & Lexington & CNG \& LPG & & & \\
\hline \multicolumn{6}{|l|}{ Clark Material ranaing Co. } \\
\hline Solectria Electonics Division & Wilmington & Electric & & & \\
\hline \multicolumn{6}{|c|}{ MICHIGAN } \\
\hline Detroit Diesel Corp. & Detroit & NG \& Alc & Gillig Corporation & Brown City & NG, LPG, Alc \\
\hline Ford Motor Company & Dearborn & NG, LPG, Alc & $\begin{array}{l}\text { TECODRIVE/Thermo } \\
\text { Power Corporation }\end{array}$ & $\begin{array}{l}\text { Sterling } \\
\text { Heights }\end{array}$ & NG \& LPG \\
\hline $\begin{array}{l}\text { GMC Truck Division, } \\
\text { General Motors Corp. }\end{array}$ & Pontiac & LPG & & & \\
\hline \multicolumn{6}{|c|}{ NEBRASKA } \\
\hline Cushman & Lincoln & Electric & H Power Corp. & Belleville & Electric \\
\hline \multicolumn{6}{|c|}{ NEVADA } \\
\hline Amectran Corporation & Las Vegas & Electric & & & \\
\hline \multicolumn{6}{|c|}{ NEW JERSEY } \\
\hline $\begin{array}{l}\text { Atlantic Detroit } \\
\text { Diesel-Allison, Inc. }\end{array}$ & Lodi & CNG,LPG,Alc & & & \\
\hline
\end{tabular}

\section{NEW MEXICO}

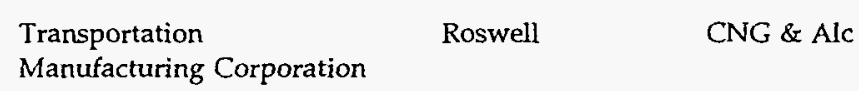

\section{NEW YORK}

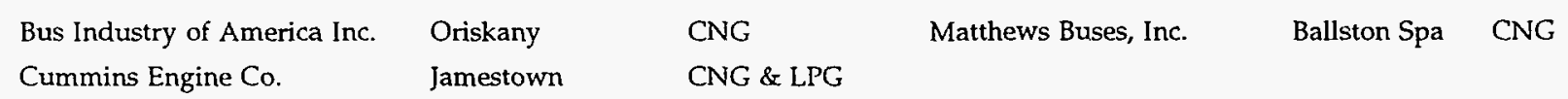

\section{NORTH CAROLINA}

\begin{tabular}{|c|c|c|c|c|c|}
\hline Cummins Engine Co & Rocky Mount & NG & Volvo/White Trucks & Greensboro & NG \\
\hline Thomas Built Busses, Inc. & High Point & CNG \& Elec & & & \\
\hline \multicolumn{6}{|c|}{ OHIO } \\
\hline $\begin{array}{l}\text { Crown Equipment } \\
\text { Corporation }\end{array}$ & Wooster & Electric & $\begin{array}{l}\text { Hercules Engine } \\
\text { Company }\end{array}$ & Canton & $\mathrm{CNG}$ \\
\hline Flexible Corp., The & Delaware & NG \& Alc & & & \\
\hline
\end{tabular}

\section{OKLAHOMA}

Crane Carrier Company Tulsa CNG

\section{OREGON}

NACCO Material Handling Oreland CNG \& LPG

Group, Inc. 
Table F2. Original Equipment Manufacturers (Continued)

\begin{tabular}{|c|c|c|c|c|c|}
\hline Company Name & City & Fuel Type & Company Name & City & Fuel Type \\
\hline \multicolumn{6}{|c|}{ TENNESSEE } \\
\hline $\begin{array}{l}\text { Advanced Vehicle Systems } \\
\text { (AVS) }\end{array}$ & Chattanooga & Electric & & & \\
\hline \multicolumn{6}{|c|}{ TEXAS } \\
\hline Composite Center, Inc. & Haslet & CNG \& LNG & $\begin{array}{l}\text { So. Central Electric } \\
\text { Vehicle Consortium }\end{array}$ & $\begin{array}{l}\text { College } \\
\text { Station }\end{array}$ & Eletric \\
\hline Empyrium, Inc. & San Antonio & Electric & Southline Equipment Co. & Houston & CNG, LPG, EV \\
\hline
\end{tabular}

Note: $L P G=$ Liquefied Petroleum Gases; $C N G=$ Compressed Natural Gas; NG = Natural Gas; Alc = Alcohol; EV = Electric Vehicle; M85 = mixture of $85 \%$ Methanol, $15 \%$ Gasoline.

Source: Energy Information Administration, Office of Coal, Nuclear, Electric, and Alternate Fuels, " Alternative Fueled Vehicle Contacts Data Base." 
Table F3. Training Centers by State

\begin{tabular}{|c|c|c|c|}
\hline Company Name & City & Company Name & City \\
\hline \multicolumn{4}{|c|}{ CALIFORNIA } \\
\hline $\begin{array}{l}\text { Alternative Energy Technology } \\
\text { Training Center }\end{array}$ & Palm Desert & IMPCO Technologies, Inc. & Cerritos \\
\hline Burkhardt Turbines & Fort Bragg & Siemens Solar Industries & Camarillo \\
\hline Electro-Automotive & Felton & & \\
\hline
\end{tabular}

\section{COLORADO}

Red Rocks Community College Lakewood

\section{CONNECTICUT}

B.C. Institute of Technology

British Columbia

Centennial Coillge of Applied Arts

Ontario and Technology

\section{FLORIDA}

Motorfuelers, Inc.

Clearwater

Sebring Auto-Cycle Institute

Sebring

\section{MICHIGAN}

Beacon Power Systems

Great Lakes Electrathon Association
Troy

Sparta
Jordan College Energy Institute

Milford Training Center
Comstock Park

Milford

\section{NEBRASKA}

National Alterantive Fuels

Training \& Awareness Pr

Columbus

NEVADA

NGV Institute Las Vegas

\section{NEW MEXICO}

Santa Fe Community College Sante Fe

\section{NEW YORK}

\section{OHIO}

Hocking College

Nelsonville

Northwestern College

Lima

\section{OKLAHOMA}

$\begin{array}{ll}\begin{array}{l}\text { Alternative Fuels Program/Dept of } \\ \text { Central Services }\end{array} & \text { Oklahoma City } \\ \begin{array}{l}\text { Autry Technology Center } \\ \text { Canadian Valley Vo-Tech }\end{array} & \begin{array}{l}\text { Enid } \\ \text { Chickasha }\end{array} \\ \text { Canadian Valley Vo-Tech } & \text { El Reno } \\ \text { Central Vo-Tech } & \text { Drumright } \\ \text { Francis Tuttle Vo-Tech Center } & \text { Oklahoma City } \\ \text { Gordon Cooper Vo-Tech } & \text { Shawnee }\end{array}$

Kiamichi Vo-Tech School

Mid-America Vo-Tech School

Oklahoma State University -

Okmulgee

Pioneer Technology Center

Stewart \& Stevenson Power, Inc.

Tom Gorman Company

Tri-County Area Vo-Tech School

\section{McAlester}

Wayne

Okmulgee

Ponca City

Commerce City

Tulsa

Bartlesville 
Table F3. Training Centers by State (Continued)

\begin{tabular}{l|l|l|l|}
\hline Company Name & City & Company Name & City \\
\hline
\end{tabular}

OKLAHOMA (Continued)

\begin{tabular}{|c|c|c|c|}
\hline $\begin{array}{l}\text { Great Plains Area Vo-Tech } \\
\text { Indian Capital Vo-Tech }\end{array}$ & $\begin{array}{l}\text { Lawton } \\
\text { Muskogee }\end{array}$ & $\begin{array}{l}\text { Tri-Fuels, Inc. } \\
\text { Tulsa Technology Center }\end{array}$ & $\begin{array}{l}\text { Tulsa } \\
\text { Tulsa }\end{array}$ \\
\hline \multicolumn{4}{|c|}{ PENNSYLVANIA } \\
\hline $\begin{array}{l}\text { Delaware County Community } \\
\text { College }\end{array}$ & Media & Philadelphia Electric Company & Berwyn \\
\hline \multicolumn{4}{|c|}{ TEXAS } \\
\hline Enfuels & Houston & Hoffman \& Associates & Austin \\
\hline MESA Environmental & Ft Worth & Trans-Star Technologies & Dallas \\
\hline Squib Taylor & Dallas & $\begin{array}{l}\text { Texas State Technical } \\
\text { College/Waco }\end{array}$ & Waco \\
\hline $\begin{array}{l}\text { Tarrant County Junior Community } \\
\text { College }\end{array}$ & Fort Worth & Tren Fuel & Austin \\
\hline Texas Railroad Commission & Austin & & \\
\hline
\end{tabular}

\begin{tabular}{|c|c|c|c|}
\hline Automotive Service Excellence & Herndon & Carburetion Labs East & Warrenton \\
\hline \multicolumn{4}{|c|}{ WEST VIRGINIA } \\
\hline West Virginia University & Morgantown & & \\
\hline \multicolumn{4}{|c|}{ WISCONSIN } \\
\hline Automotive Natural Gas, Inc. & Milton & EDO ANGI & Milton \\
\hline
\end{tabular}

Source: Energy Information Administration, Office of Coal, Nuclear, Electric, and Alternate Fuels, "Altemative Fueled Vehicle Contacts Data Base." 



\section{Glossary}

Aftermarket Conversion: A standard, conventionally fueled, factory-produced vehicle to which equipment has been added that enables the vehicle to operate on an alternative fuel.

Alcohols $\left(\mathrm{CH}_{3}-\left(\mathrm{CH}_{2}\right)_{n}-\mathrm{OH}\right)$ : The family name of a group of organic chemical compounds composed of carbon, hydrogen, and oxygen. The series of molecules vary in chain length and are composed of a hydrocarbon, plus a hydroxyl group (for example, methanol, ethanol, and tertiary butyl alcohol).

Aldehydes: One of several families of compounds formed as products of incomplete combustion in engines using gasoline, methanol, ethanol, propane, or natural gas as fuels. As a general rule of thumb, the presence of methanol or methyl ethers in the fuel will lead to formaldehyde as the primary aldehyde in the exhaust, while ethanol or ethyl ethers will lead to acetaldehyde as the primary aldehyde in the exhaust. In both cases, other aldehydes are present, but in much smaller quantities. Formaldehyde and acetaldehyde are toxic and possibly carcinogenic.

Alternative Fuel: As defined pursuant to the EPACT, methanol, denatured ethanol, and other alcohols, separately or in mixtures of 85 percent by volume or more (or other percentage not less than 70 as determined by DOE rule) with gasoline or other fuels, CNG, LNG, LPG, hydrogen, coal-derived liquid fuels, fuels other than alcohols derived from biological materials, electricity, or any other fuel determined to be substantially not petroleum and yielding substantial energy security benefits and substantial environmental benefits.

Alternative Fueled Vehicle (AFV): A vehicle either designed and manufactured by an original equipment manufacturer or a converted vehicle designed to operate in either dual-fuel, flexible-fuel, or dedicated modes on fuels other than gasoline or diesel. This does not include a conventional vehicle that is limited to operation on blended or reformulated gasoline fuels.

Alternative Fueled Vehicle Converter: An organization (including companies, government agencies, and utilities), or an individual who performs conversions involving alternative fueled vehicles. An AFV converter can convert (1) conventionally fueled vehicles to AFV's, (2) AFV's to conventionally fueled vehicles, or (3) AFV's to another alternative fuel.

Barrel: A volumetric unit of measure for crude oil and petroleum products equivalent to 42 U.S. gallons.
Bi-Fueled Vehicle: A vehicle with two separate fuel systems designed to run on either an alternative fuel or conventional fuel using only one fuel at a time.

Biodiesel: Any liquid biofuel suitable as a diesel fuel substitute or diesel fuel additive or extender. A diesel substitute made from transesterification of oils of vegetables such as soybeans, rapeseed, or sunflowers (end product known as methyl ester) or from animal tallow (end product known as methyl tallowate). Biodiesel can also be made by transesterification of hydrocarbons produced by the Fisher-Tropsch process from agricultural byproducts such as rice hulls.

British Thermal Unit (Btu): A standard unit for measuring the quantity of heat energy equal to the quantity of heat required to raise the temperature of 1 pound of water by 1 degree Fahrenheit.

California Air Resources Board (CARB): A State regulatory agency charged with regulating the air quality in California. Air quality regulations established by the Board and often stricter than those set by the Federal Government.

Carbon Cycle: All reservoirs and fluxes of carbon; usually thought of as a series of the four main reservoirs of carbon interconnected by pathways of exchange. The four reservoirs, regions of the Earth in which carbon behaves in a systematic manner, are the atmosphere, terrestrial biosphere (usually includes freshwater systems), oceans, and sediments (includes fossil fuels). Each of these global reservoirs may be subdivided into smaller pools ranging in size from individual communities or ecosystems to the total of all living organisms (biota). Carbon exchanges from reservoir to reservoir by various chemical, physical, geological, and biological processes.

Carbon Dioxide $\left(\mathrm{CO}_{2}\right)$ : A colorless, odorless, nonpoisonous gas that is a normal part of the ambient air. Carbon dioxide is a product of fossil fuel combustion. Although $\mathrm{CO}_{2}$ does not directly impair human health, it is a greenhouse gas that traps the earth's heat and contributes to the potential for global warming.

Carbon Monoxide (CO): A colorless, odorless gas slightly lighter than air. It is poisonous if inhaled, in that it combines with blood hemoglobin to prevent oxygen transfer. It is produced by the incomplete combustion of fossil fuels with a limited oxygen supply (as in automobiles). It is a major component of urban air pollution, which can be reduced by the blending of an oxygen-bearing compound such as alcohols and ethers into hydrocarbon fuels. 
Chlorofluorocarbons (CFC's): A family of inert, nontoxic, and easily liquified chemicals used in refrigeration, air conditioning, packaging, and insulation, or as solvents or aerosol propellants. Because they are not destroyed in the lower atmosphere, they drift into the upper atmosphere where their chlorine components destroy ozone.

Clean Alternative Fuel: Any fuel (including methanol, ethanol, or other alcohols (including any mixture thereof containing 85 percent or more by volume of such alcohol with gasoline or other fuels), reformulated gasoline, diesel, natural gas, liquefied petroleum gases, and hydrogen) or power source (including electricity) used in a clean fuel vehicle that complies with the standards and requirements of the Clean Air Act Amendments of 1990.

Compressed Natural Gas (CNG): Natural gas compressed to a volume and density that is practical as a portable fuel supply (even when compressed, natural gas is not a liquid).

Carbon Monoxide Nonattainment Area: Areas with carbon monoxide design values of 9.5 parts per million or more (generally based on data for 1988 and 1989).

Converted Vehicle: A vehicle originally designed to operate on gasoline that has been modified or altered to operate on an alternative fuel.

Criteria Pollutant: A pollutant determined to be hazardous to human health and regulated under the Environmental Protection Agency's National Ambient Air Quality Standards. The 1970 amendments to the Clean Air Act require the Environmental Protection Agency to describe the health and welfare impacts of a pollutant as the criteria for inclusion in the regulatory regime.

Dedicated Vehicle: A vehicle designed to operate solely on one alternative fuel.

Diesel Fuel: A complex mixture of hydrocarbons with a boiling range between approximately 350 and 650 degrees Fahrenheit. Diesel fuel (simply referred to as "diesel") is composed primarily of paraffins and naphthenic compounds that auto-ignite from the heat of compression in a diesel engine. Diesel is used mainly by heavy-duty road vehicles, construction equipment, locomotives, and by marine and stationary engines.

Dual-Fueled Vehicle: A vehicle designed to operate on a combination of alternative fuel, such as CNG or LPG, and conventional fuel, such as gasoline or diesel. These vehicles have two separate fuel systems which inject both fuels simultaneously into the engine combustion chamber.

E10: Gasohol
E85: A fuel containing a mixture of 85 percent ethanol and 15 percent gasoline.

E95: A fuel containing a mixture of 95 percent ethanol and 5 percent gasoline.

Energy Efficiency: The inverse of energy intensiveness: the ratio of energy outputs from a process to the energy inputs (for example, miles traveled per gallon of fuel).

Environmental Protection Agency (EPA): A government agency, established in 1970. Its responsibilities include the regulation of fuels and fuel additives.

Ethyl Tertiary Butyl Ether (ETBE), $\left(\mathrm{CH}_{3}\right)_{3} \mathrm{COC}_{2} \mathrm{H}_{5}$ : A colorless, flammable, oxygenated hydrocarbon blend stock formed by the catalytic etherification of isobutylene with ethanol.

Ethanol $\left(\mathrm{C}_{2} \mathrm{H}_{5} \mathrm{OH}\right)$ : Otherwise known as ethyl alcohol, alcohol, or grain-spirit. A clear, colorless, flammable oxygenated hydrocarbon with a boiling point of 78.5 degrees Celsius in the anhydrous state. However, it forms a binary azeotrope with water, with a boiling point of 78.15 degrees Celsius at a composition of 95.57 percent by weight ethanol. It is used in the United States as a gasoline octane enhancer and oxygenate (10 percent concentration). Ethanol can also be used in high concentrations in vehicles optimized for its use.

Ether: The family name applied to a group of organic chemical compounds composed of carbon, hydrogen, and oxygen, and which are characterized by an oxygen atom attached to two carbon atoms (for example, methyl tertiary butyl ether).

Fleet: A group of 20 or more light-duty vehicles which are capable of being centrally-fueled and are primarily used in a consolidated metropolitan statistical area with a population of 250,000 or more. These vehicles are owned, operated, leased, or controlled by a government entity, or by another person that controls 50 or more such vehicles. Exceptions include: rental vehicles, motor vehicles held for sale, test vehicles, law enforcement vehicles, emergency motor vehicles, military vehicles, nonroad vehicles (farm and construction equipment), and vehicles garaged at personal residences at night.

Flexible-Fueled Vehicle: A vehicle with the ability to operate on alternative fuels (such as M85 or E85), 100 percent traditional fuels, or a mixture of alternative fuel and tradition fuels.

Gasohol: A mixture of 10 percent anhydrous ethanol and 90 percent gasoline by volume. There are other fuels that contain ethanol and gasoline, but these fuels are not referred to as gasohol. Future gasoline/ethanol mixtures will contain either 5.7 or 7.7 percent ethanol. 
Global Warming: The theoretical escalation of global temperatures caused by the greenhouse effect.

Greenhouse Effect: A popular term used to describe the roles of water vapor, carbon dioxide, and other trace gases in keeping the Earth's surface warmer than it would be otherwise. These radiatively active gases are relatively transparent to incoming shortwave radiation, but are relatively opaque to outgoing long wave radiation. The latter radiation, which would otherwise escape to space, is trapped by these gases within the lower levels of the atmosphere. The subsequent reradiation of some of the energy back to the Earth maintains the surface at temperatures higher than they would be if the gases were absent.

Greenhouse Gases: Those gases, such as water vapor, carbon dioxide, tropospheric ozone, nitrous oxide, and methane, that are transparent to solar radiation but opaque to long wave radiation. Their action is similar to that of increased humidity in a greenhouse.

Gross Vehicle Weight Rating: The weight of the empty vehicle plus the maximum anticipated load weight.

Heavy-Duty Vehicles (HDV'S): Pursuant to the EPACT, Trucks and buses having a gross vehicle weight rating of 8,500 pounds or more.

Hydrogen $\left(\mathrm{H}_{2}\right)$ : The lightest of all gases, the element (hydrogen) occurs chiefly in combination with oxygen in water. It also exists in acids, bases, alcohols, petroleum, and other hydrocarbons.

Light-Duty Vehicles (LDV): Automobiles and trucks having a gross vehicle weight rating of less than 8,500 pounds.

Liquefied Natural Gas (LNG): Natural gas that has been refrigerated to temperatures at which it exists in a liquid state.

Liquefied Petroleum Gases (LPG): Propane, propylene, normal butane, butylene, isobutane, and isobutylene produced at refineries or natural gas processing plants (includes plants that fractionate raw natural gas plant liquids).

Lower Heating Value (LHV): The Btu content per unit of fuel excluding the heat from the condensation of water vapor in the fuel.

M85: A fuel containing a mixture of 85 percent methanol and 15 percent gasoline.

M100: 100 percent (neat) methanol.

Methane $\left(\mathrm{CH}_{4}\right)$ : The simplest of the hydrocarbons and the chief constituent of natural gas. Methane, a gas at normal temperatures and pressures, boils at -263 degrees Fahrenheit.
Methanol $\left(\mathrm{CH}_{3} \mathrm{OH}\right)$ : A colorless liquid with essentially no odor and very little taste. The simplest alcohol, it boils at 64.7 degrees Celsius. It is miscible with water and most organic liquids (including gasoline) and is extremely flammable, burning with a nearly invisible blue flame. Methanol is produced commercially by the catalyzed reaction of hydrogen and carbon monoxide. It was formerly derived from the destructive distillation of wood, which caused it to be known as wood alcohol.

Methyl Tertiary Butyl Ether (MTBE), $\left(\mathrm{CH}_{3}\right)_{3} \mathrm{COCH}_{3}$ : A colorless, flammable, liquid oxygenated hydrocarbon that contains 18.15 percent oxygen and has a boiling point of 55.2 degrees Celsius. It is a fuel oxygenate produced by reacting methanol with isobutylene.

Midwest Census Region: This region includes the following States: Illinois, Indiana, Iowa, Kansas, Michigan, Minnesota, Missouri, Nebraska, North Dakota, Ohio, South Dakota, and Wisconsin.

Mcf: Million cubic feet

Motor Bus: Rubber-tired, self-propelled, manuallysteered bus with the fuel supply on board the vehicle. Motor bus types include intercity, school, and transit.

Motor Gasoline Blending of Oxygenates: Blending of gasoline and oxygenates under the Environmental Protection Agency's "Substantially Similar" Interpretive Rule (56 FR [February 11, 1991]).

Natural Gas: A mixture of hydrocarbon compounds and small quantities of various nonhydrocarbons existing in the gaseous phase or in solution with crude oil in natural underground reservoirs at reservoir conditions. The primary constituent compound is $\mathrm{CH}_{4}$. Gas coming from wells also can contain significant amounts of ethane, propane, butanes, and pentanes, and widely varying amounts of carbon dioxide and nitrogen. Pipeline-quality natural gas has had most, but not all natural gas liquids and other contaminants removed. On board a vehicle, it is stored under high pressure at 2,500 to 3,600 pounds per square inch ( $\mathrm{psi}$ ). A gallon of natural gas at 2,000 psi contains about $20,000 \mathrm{Btu}$; at $3,600 \mathrm{psi}$, a gallon contains about 30,000 Btu.

Neat Alcohol Fuels: Straight alcohol (not blended with gasoline) that may be either in the form of ethanol or methanol. Ethanol, as a neat alcohol fuel, does not need to be at 200 proof; therefore, it is often used at 180 to 190 proof (90 to 95 percent). Most methanol fuels are not strictly "neat," since 5 to 10 percent gasoline is usually blended in to improve its operational efficiency.

Nitrogen Oxides $\left(\mathrm{NO}_{\mathrm{x}}\right)$ : Air-polluting gases contained in automobile emissions, which are regulated by the 
Environmental Protection Agency. They comprise colorless nitrous oxide $\left(\mathrm{N}_{2} \mathrm{O}\right)$ (otherwise known as dinitrogen monoxide, or as the anaesthetic "laughing gas"), colorless nitric oxide (NO), and the reddishbrown-colored nitrogen dioxide $\left(\mathrm{NO}_{2}\right)$. Nitric oxide is very unstable, and on exposure to air it is readily converted to nitrogen dioxide, which has an irritating odor and is very poisonous. Nitrogen dioxide contributes to the brownish layer in the atmospheric pollution over some metropolitan areas. Other nitrogen oxides of less significance are nitrogen tetroxide $\left(\mathrm{N}_{2} \mathrm{O}_{4}\right)$ and nitrogen pentoxide $\left(\mathrm{N}_{2} \mathrm{O}_{5}\right)$. Nitrogen oxides are sometimes collectively referred to as " $\mathrm{NO}_{x}$ " where ' $x$ ' represents any proportion of oxygen to nitrogen.

Nonattainment Area: A region that exceeds minimum acceptable National Ambient Air Quality Standards (NAAQS) for one or more criteria pollutants, in high population density areas, in accordance with the U.S. Census Bureau population statistics. Such regions (areas) are required to seek modifications to their State Implementation Plans, setting forth a reasonable timetable using means (approved by the Environmental Protection Agency) to achieve attainment of NAAQS by a certain date. Under the Clean Air Act, if a nonattainment area fails to attain NAAQS, the Environmental Protection Agency may superimpose a Federal Implementation Plan with stricter requirements or impose fines, construction bans, or cutoffs in Federal grant revenues until the area achieves applicable NAAQS.

Northeast Census Region: This region includes the following States: Connecticut, Maine, Massachusetts, New Hampshire, New Jersey, New York, Pennsylvania, Rhode Island, and Vermont.

Original Equipment Manufacturers (OEM's): Vehicle manufacturers that provide the original design and materials for assembly and manufacture of their product. They are directly responsible for manufacturing and modifying vehicles, making the vehicles commercially available, and providing a warranty for the finished product.

Oxygenated Fuel: Any fuel substance containing oxygen (includes oxygen-bearing compounds such as ethanol and methanol). Oxygenated fuel tends to give a more complete combustion of its carbon into carbon dioxide (rather than monoxide), thereby reducing air pollution from exhaust emissions.

Oxygenated Gasoline: Gasoline with an oxygen content of 1.8 percent or higher, by weight, that has been formulated for use in motor vehicles.

Ozone $\left(\mathrm{O}_{3}\right)$ : An oxygen molecule with 3 oxygen atoms that occurs as a blue, harmful, pungent-smelling gas at room temperature. The stratospheric ozone layer, which is a concentration of ozone molecules located at 6 to 30 miles above sea level, is in a state of dynamic equilibrium. Ultraviolet radiation forms the ozone from oxygen, but can also reduce the ozone back to oxygen. The process absorbs most of the ultraviolet radiation from the sun, shielding life from the harmful effects of radiation. Trapospheric Ozone is normally present at the ground level in low concentrations. In cities where high levels of air pollutants are present, the action of the sun's ultraviolet light can, through a complex series of reactions, produce a harmful concentration of ozone in the air. The resulting air pollution is known as photochemical smog. Certain air pollutants (e.g., chlouroflurocarbons) can drift up into the atmosphere and damage the balance between ozone production and destruction, resulting in a reduced concentration of ozone in the layer.

Ozone Precursor: A chemical compound (such as nitrogen oxides, methane, nonmethane hydrocarbons and hydroxyl radicals) that, in the presence of solar radiation, reacts with other chemical compounds to form ozone.

Petroleum: A generic term applied to oil and oil products in all forms (such as crude oil, lease condensate, unfinished oil, refined petroleum products, natural gas plant liquids, and finished petroleum products).

Propane $\left(\mathrm{C}_{3} \mathrm{H}_{8}\right)$ : A normally gaseous straight-chain hydrocarbon, it is a colorless paraffinic gas that boils at a temperature of -43.67 degrees Fahrenheit. It is extracted from natural gas or refinery gas streams.

Reformulated Gasoline (RFG): Gasoline whose composition has been changed (from that of gasolines sold in 1990) to 1) include oxygenates, 2) reduce the content of olefins and aromatics and volatile components, and 3 ) reduce the content of heavy hydrocarbons to meet performance specifications for ozone-forming tendency and for release of toxic substances (benzene, formaldehyde, acetaldehyde, 1,3-butadiene, and polycyclic organic matter) into the air from both evaporation and tailpipe emissions.

Replacement Fuel: The portion of any motor fuel that is methanol, ethanol, or other alcohols, natural gas, liquefied petroleum gases, hydrogen, coal derived liquid fuels, electricity (including electricity from solar energy), ethers, or any other fuel the Secretary of Energy determines, by rule, is substantially not petroleum and would yield substantial energy security benefits and substantial environmental benefits.

South Census Region: This U.S. Census Bureau region consists of the following States: Alabama, Arkansas, Delaware, District of Columbia, Florida, Georgia, Kentucky, Louisiana, Maryland, Mississippi, North Carolina, Oklahoma, South Carolina, Tennessee, Texas, Virginia, and West Virginia. 
Tax Incentives: In general, a means of employing the tax code to stimulate investment in or development of a socially desirable economic objective without the direct expenditure from the budget of a given unit of government. Such incentives can take the form of tax exemptions or credits.

Tertiary Amyl Methyl Ether (TAME) $\left(\mathrm{CH}_{3}\right)_{2}\left(\mathrm{C}_{2} \mathrm{H}_{5}\right) \mathrm{COCH}_{3}$ : An oxygenate blend stock formed by the catalytic etherification of isoamylene with methanol.

Vehicle Use: For the purpose of this publication, vehicle use pertains to mileage accumulated during the specified calendar-year reporting period as a result of intended business or personal use. Mileage from (1) vehicle testing prior to first sale, (2) transport of the vehicle to the destination of first sale, or (3) emergency use, should not be included.

West Census Region: This U.S. Census Bureau region consists of the following States: Alaska, Arizona, California, Colorado, Hawaii, Idaho, Montana, Nevada, New Mexico, Oregon, Utah, Washington, and Wyoming. 